UC-NRLF

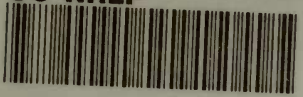

\$D $54 \quad 635$ 

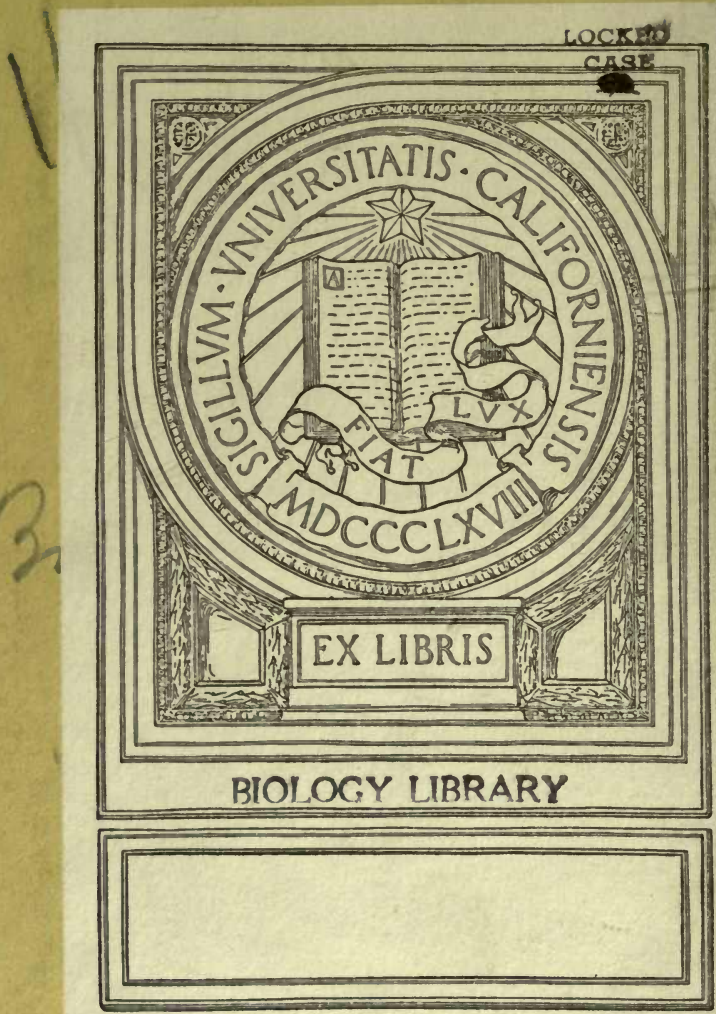
36 S KNowars

TOFNS

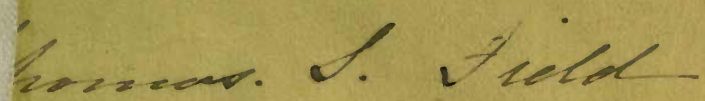

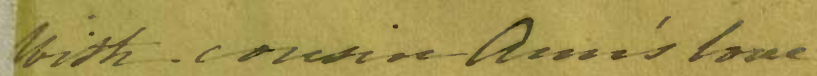

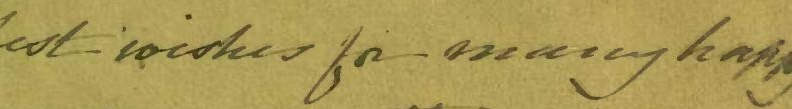

selevines of the diser.

feney $b+1600$ 




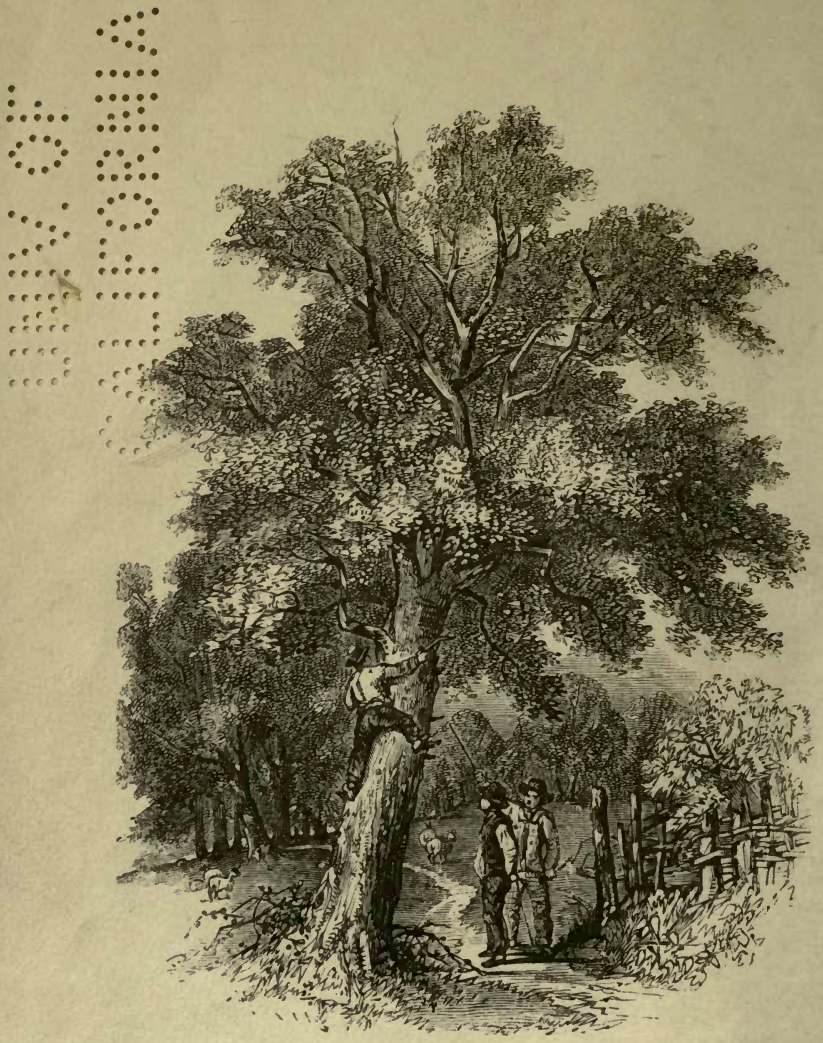




\section{BIRDS' NESTS.}

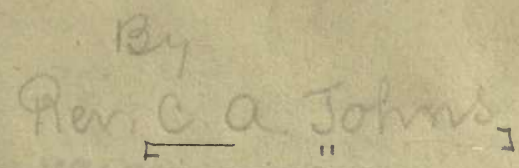

PUBLISHED UNDER TIE DIRECTION OF

THE COMMITTEE OF GENERAX IITERATURE AND EDUCATION.

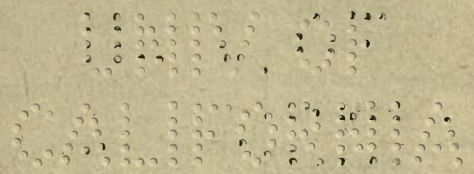

\section{O N D O N :}

SOCIETY FOR PROMOIING CHRISTLAN KNOWLEDGE;

SOLD AT THE DEPOSITORIES:

GREAT QUEEN STREET, LINCOLN'S INN FIELDS;

4, ROYAL EXCHANGE; 16, HANOVFR STREET, IIANOVER SQUARE;

AND BY ALI BOOKSERLERS.

$$
\text { [1854 }
$$




\section{$t Q L 675$ \\ $\sqrt{6}$}

BIOLOGY

LIBRARY

\section{BIOLOGY LIBRARY}

औ

आओ

R. CTAA, PRINTER, BREAD STREIT HILL. 


\section{N D E X.}

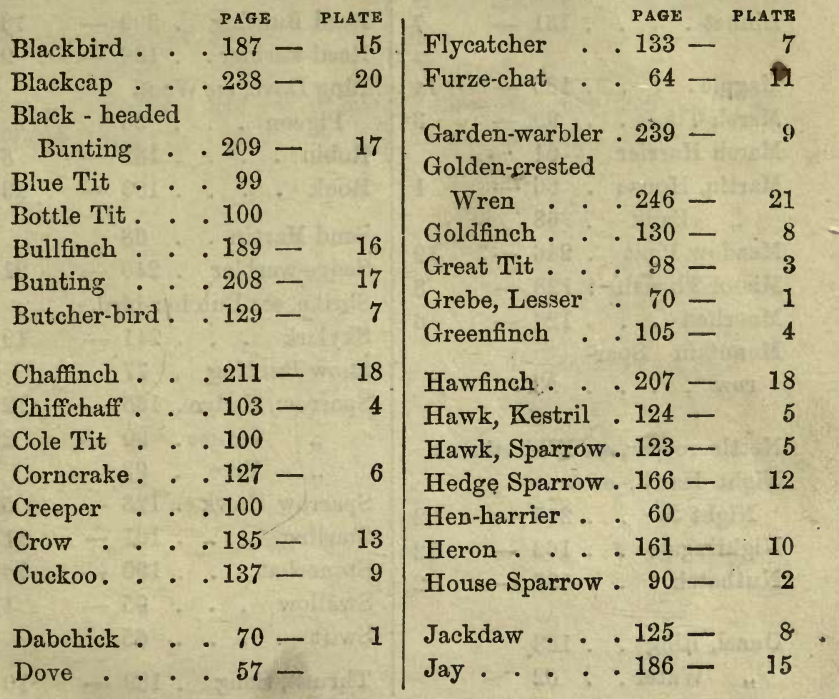


PAGE PLATE

Kestril . . . 124 -

Kingfisher . 63 -

Landrail . . . 127 -

Lapwing . . 244 -

Lark . . . 241 -

Lesser Grebe. . 70 -

Lesser White-

throat . . 105 -

Linnet . . . 131 -

Magpie. . . 185 -

Marsh Tit. . . 99 -

Marsh Harrier . 61

Martin, House . 66 -

Bankk . 68

Meadow Pipit . 246 -

Missel Thrush . 128 -

Moorhen . . . 126 -

Mountain Spar-

row . . 93

Nettlecreeper, see Whitethroat.

Night Hawk, or

Night Jar . . 245 -

Nightingale . 168 - 12

Nuthatch . . 97 -

Ouzel, Ring . 188

"Water. . 62
PAGE

PLATE

Owl. . . $55-1$

Peewit, see Lapwing.

Pipit, Meadow . 246 - 19

"Tree . .246- 20

Quail . . . 128 - 22

Raven . . $182-14$

Redbreast. . $132-8$

Redstart . . 164 - 12

Reed Bunting . 209 - 18

Reed-warbler . 136 - 9

Ring Dove, see Wood

Pigeon . . 56

Robin . . $132-8$

Rook . . $183-13$

Sand-Martin . 68

Sedge-warbler . 240 - 21

Shrike, see Butcher-bird.

Skylark . . $241-19$

Snow Bunting . 77

Sparrow, Hedge. 166 - 12

$$
\begin{array}{ll}
\text { " House. } 90- \\
\text { Tree } 93
\end{array}
$$

Sparrow Hawk . 123 - 5

Starling . . $161-11$

Stonechat. . $190-16$

Swallow . . 95- 1

Swift . . . 65

Thrush, Song $.189-16$ 


\section{INIEX.}

vii

\begin{tabular}{|c|c|c|c|c|c|}
\hline & PAGE & & & PAGE & PLATE \\
\hline Thrush, Missel & $.128-$ & 3 & Water Wagtail & . $93-$ & 2 \\
\hline Tit, Blue, or Tom & ค 99 & & Wheatear. & $.163-$ & 11 \\
\hline "Cole . . & .100 & & Whinchat. & . $164-$ & 11 \\
\hline Great . & . $98-$ & 3 & Whitethroat. & . $239-$ & 21 \\
\hline Long-tailed & 100 & & Willow Wren & $.102-$ & 3 \\
\hline , Marsh. . & - $99-$ & 3 & Woodlark. . & .243 & \\
\hline ree Pipit. & . 246 - & 20 & Woodpecker . & . $57-$ & 1 \\
\hline Turtle Dove . & . 57 & & Wood Pigeon & . 56 & \\
\hline & & & Wood Wren . & . $104-$ & 4 \\
\hline Narbler, Garden & ก $239-$ & 9 & Wren . . & . $104-$ & 3 \\
\hline " Reed & $.136-$ & 9 & Wryneck . . & . 60 & \\
\hline$" \quad$ Sedge & . $240-$ & 20 & Yellow Hamme & $208-$ & 17 \\
\hline Tater Ouzel . & - 62 & & Yellow Wagtail & . 94 & \\
\hline
\end{tabular}




\section{UIRECTIONS TO THE BINDER FOR PLACING THE PLATES.}

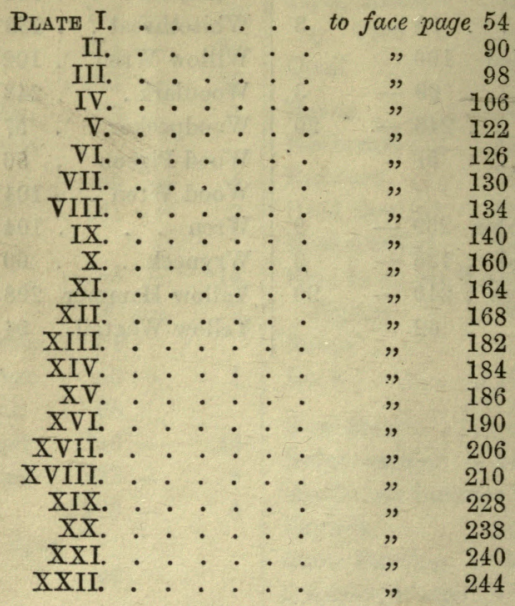

\section{ERRATA.}

Plate IV.-For "leseer" read "lesser."

- XI.-For " wheather" read "wheatear."

- XXI.-For "double-crested wren" read "golden-crested wren." 


\section{BIRDS' NESTS.}

ONE day, Henry Miller came running into the house, calling at the top of his voice,-

"Papa, come into the orchard as fast as you can; there are some boys in one of the appletrees; one of them has a knife in his hand, and he is cutting the tree, but I don't know what for."

Mr. Miller left his book and made all haste into the orchard, and found, as Henry had said, two boys in the tree and another standing below. All three were so intent on the mischief that was going on, that neither of them noticed his approach; but just as Mr. Miller caught the last by the collar, one of those in the tree cried out,-

"I've got him—oh, what a pretty bird !" 
Hearing no reply from his comrade below, lif lroked lown and to his horror saw that they were all caught.

"Come down both of you directly," said Mr. Miller, quietly.

The boys, seeing that there was no help for them, came down, looking much frightened.

"First," said Mr. Miller, "let that bird fly." The boy opened his hand, and the poor bird flew off like an arrow.

"Now, what business have you in my orchard? Have you forgotten what happened to the boys who were caught last autumn in Mr. Long's orchard? A fortnight in gaol was paying dear, I think, for a pocketful of apples." "But we did not come to steal apples, Sir," said the elder of the boys.

"I know very well that you could not steal apples in May; but I don't know whether you would not have tried to do so when the season comes, if I had not caught you now. Once get used to breaking fences and trespassing in 
spring, and trespassing for dishonest purposes will soon grow easy. What have you been doing with that knife?"

"If you please, Sir," said the eldest boy, "my brother Tom and Joe Square and I were going birds'-nesting; and as we were walking down the lane, we saw a bird fly into that hole in the apple-tree, and so we thought there must be a nest there ; and Joe Square said-" "Stop," said Mr. Miller, "don't tell me what Joe Square said, but what you did. You are the oldest of the party, and are most to blame, whatever may have been said. I think you must be a cowardly fellow, and quite ready to do a cruel thing, or you would not try to shift the blame from yourself to your companion. Joe Square, you have the name of being a truthful boy at school; you go on with the story, and tell me what brought you into. the orchard."

"We did not mean to do any harm, Sir," continued Joe; "we could not find any nests B 2 
in the fields, so we thought we would come into the orchard and look for a missel-thrush's nest in the apple-trees. So we found a place where the cow had broken down the fence, and came in. As we were walking along, I saw a bird with a blue back fly into that hole, and we thought there must be a nest in it ; so we climbed up very quietly, and I held my cap before the hole, that we might catch the old bird; but it would not come out. Then I tried to put my hand in, but the hole was not large enough; so I lent Bill Johnson my knife, and he cut away the wood round the hole, to make it larger, and just as you came up, he put in his hand and caught the bird."

"And pray," said Mr. Miller, "was it any pleasure to you to terrify a poor harmless bird, that risked its life in order that it might protect its nest? If robbers were to attack your house in the night, and you were strong enough to defend your mother and sisters, would you 


\section{BIRDS' NESTS.}

stay and fight for them, or run away to save yourself?"

Joe held down his head and said nothing. Perhaps he recollected that his mother had that very morning forbidden him to meddle with a nest which a robin had built in the garden tool-house. Johnson looked as if he would have said something impudent, if he had not been afraid.

"Now," continued Mr. Miller, "you have committed a trespass in my orchard, not only by breaking through the fence, but by cutting a tree. If I were to take you before a magistrate, he would, I dare say, fine you heavily; but this would be no punishment to you, Johnson, for your father would have to pay; and from what I know of your character, you are too selfish to be pained at what may happen to him, or indeed to any one but yourself. Your mother, Joe, cannot afford it; and besides, so pious and honest a woman as she is does not deserve to suffer for the faults of her children; 
because, I know, she tries to do her duty towards them. But let me give you a bit of advice : first of all, ask her whether she thinks Johnson a fit companion for you? and if she says 'No,' have as little to do with him as possible. And in the next place, whenever you find a bird's nest, look in it, if you like,that is, if you can do so without disturbing it, - but neither take the eggs, nor terrify the old birds. Pray, does your mother know where you are?"

Joe admitted that she did not.

"Well then, suppose you were not to return at the time she expects you,- - that you did not come back all night, nor to-morrow, nor next day, - what do you suppose she would think about it?"

Joe said she would be very anxious and in great grief.

"Indeed she would; words can hardly describe the agony of a mother who has lost her child ; and some such sort of agony, perhaps, 


\section{BIRDS' NESTS.}

that poor bird felt, all the while you were hacking away at her nest. Birds, who have had their young ones taken away, have been known to follow the robber for a long distance, and even to go into a house to feed them; and do you think they would do that unless they loved them almost as dearly as your mother loves you? The Bible speaks of the love of a bird for its young as one of the strongest feelings in nature. If you read the thirty-second chapter of Deuteronomy, you will see that God compares His own watchfulness over the children of Israel to the love bestowed by an eagle on its young; and the eagle we look on as the most savage of all birds. We may learn from this passage alone, that we cannot rob a bird's nest without causing suffering to one of God's creatures, that is, without being cruel. Now cruelty is a sin which is not only bad in itself, but tends more than any other sin, perhaps, to harden the heart; and your mother, Joe, has taught you too well that you should need 
me to tell you how fearful a thing it is to have a hard heart."

Mr. Miller saw that what he had said had produced a good effect on Joe, though as for the others, one of them cared for no advice that went against his own wishes, and the other was too young to understand all that was said, though he could not help feeling that he had done wrong.

"Now, boys, you may go; but remember what I have been saying to you. You did mischief to me by breaking into my orchard; you acted cruelly in frightening that poor bird from its nest; you gave way to a temptation, the natural effect of which is to harden your own hearts; and all these things are sins in the sight of God. Give over the practice altogether; try to be kind-hearted boys, and with God's blessing you will become merciful men. You know the reward that is promised to the merciful."

The boys were glad enough to be let off so 
easily; Joe, thankful to have been spared the disgrace of being taken before a magistrate and the pain of grieving his mother; Johnson, at having escaped what he expected, and, to say the truth, richly deserved, a good flogging.

The two brothers walked away hand in hand, the elder looking angry and sulky, and the younger looking inquiringly into his brother's face. But Joe touched his hat, wiping his eyes all the while; and when Mr. Miller smiled on him, showed, by his brightened countenance, that he at least felt neither anger nor sullenness.

Mr. Miller was pleased to see, too, that he made no attempt to join his companions ; but, though they all lived in the same direction, walked some distance behind. But as they passed along the lane which skirted the orchard, he saw Johnson stop, and heard him say to Joe, in a sneering tone, "Well, there is some good, after all, in having a favourite with you when you are caught out; for if I had been by myself 
to-day, I should have been flogged handsomely."

Joe made no reply; but if his thoughts could have been heard, they would have been these: "I am not sorry that my being with you has saved you from a flogging; but I will take care not to be caught again with any one who deserves one."

Henry had been standing by all the while, listening attentively to what passed. He was very angry with the boys for breaking into his father's orchard, but still very glad that they had neither been flogged nor been taken before a magistrate. The bird's nest was, however, as great an attraction to him as it had been to the others. He had frequently looked up at the hole in the tree, and now while his father was busied in repairing the broken fence, he asked him if he knew what bird it was that the boys had caught?

"Yes," said Mr. Miller; "a nuthatch." "What, that funny bird that sticks nuts 
into the bark of the walnut-tree in the garden, and hammers at them with his head downwards? I have seen that hole in the tree before; I should have thought it was too small for him to get through. I wonder whether it is big enough for my hand, now that the boys have made it larger. Do you think there is a nest in it, papa?"

"We will see directly, as soon as I have finished my job."

"Oh, thank you, papa; but I don't think that the hole is large enough for your hand to go in."

"Well, then, in that case we can use yours. Go ask the gardener to bring a ladder, and we will see how well you can climb."

The ladder was soon brought, and as the hole was only ten or twelve feet from the ground, Henry mounted it without danger.

"Now tell me what you can see," said Mr. Miller, when his little son had reached the nest. 
"It is so dark that I cannot see much; but I can make out some dry leaves."

"Put your hand in, then, but carefully, lest there should be eggs or young ones in the nest."

"But, papa, are you sure there are no snakes nor toads in it?"

"No fear of them; snakes in this country do not climb trees, nor toads either. You will find nothing there to hurt you. Mrs. Nuthatch has taken care that there should not be even a spider."

"There is nothing here but leaves," said Henry, who had at last ventured to put his hand into the hole, and had pulled out a handful.

"Do not be too sure." said Mr. Miller; " recollect that the boys must have destroyed the nest; perhaps there may be eggs buried among them yet. But these are not leaves that you have thrown down; they are all scraps of birch-bark. Poor birds! what labour they 
must have had to strip all these from the trunks of the trees,-for I see they are quite fresh."

Down came another and another handful, and it really seemed that the nest was unfinished. Mr. Miller, however, thought that the bird would not have shown such courage in defending her nest, if it contained neither eggs nor young birds; and he was right; for presently Henry exclaimed, "I feel an egg now ; here it is, but it is broken." Mr. Miller had never seen the egg of a nuthatch before, and was glad to get a sight of even a broken one; but before the hole was emptied, another broken one was found, and three sound ones. They were very beautiful, pure white, and speckled about the larger end with two shades of purplish brown.

"We may keep these, I suppose," said Henry, "now that the nest is destroyed."

"Yes, certainly; there is no cruelty in taking the eggs, now that the nest is torn to 
pieces, and the birds have been frightened away from it."

"But is it always cruel to take birds' eggs, when the nest is not destroyed?"

"Did you not hear me tell those boys that it is cruel to give pain to any living thing; and do you not think that a bird must be pained and grieved, to have its nest torn to pieces or stolen, and its eggs broken or carried away?"

"Are hens birds?" asked Henry.

"Oh," said Mr. Miller, "I see what you are thinking of: you have been trying to set a nice trap for me, by getting me to say that it is cruel to take birds' eggs, although I often have a hen's egg for my own breakfast."

Henry looked somewhat ashamed; for, like many other little boys, he was rather given to think himself wiser than his betters.

"I will talk to you about that to-morrow. Come away, now ; I wish to read the description of the nuthatch in Yarrell's British Birds." 
When they had reached the house, the book was fetched, and Mr. Miller found that the nuthatch was there said to make its slight nest, - or rather a collection of dead leaves, moss, bits of bark and wood, - in holes of trees, and to lay from five to seven eggs, white with some pale-red spots. He found it said also, that if the hole in which it built was large, the bird plastered up part of it with mud, and that if the plastering were removed, it made all right again the first or second day after. It often has desperate battles with some kinds of tits for a favourite nesting-place; and this may be the reason why it plasters up its hole, as it is much easier to keep out an enemy from a small opening than from a large one.

Mr. Miller, on first reading this account, was almost sorry that he had taken the eggs, as he thought it possible that the bird might have returned; but on second thoughts it seemed very unlikely, that a bird that had been caught in its hole, and had had its nest 
torn to pieces, and its eggs broken, would have ever come back again.

The next thing to be done was to empty the eggs of their contents; for if they had been put away as they were, they would not only have been liable to be broken, but would have rotted and lost their colour. Accordingly he got a fine hollow straw, and having bored a hole with a pin, in a part of the egg which could be hid from sight by laying the egg on the table, he put the straw through the hole and blew gently, when both white and yolk ran out of the same hole. This, he said, was the best way of blowing eggs. The plan, which boys usually pursue, of making a hole at each end, is a bad one, since two holes weaken the shell more than one, and destroy the shape of the egg. Beside this, when eggs are placed in a museum, they will be injured by insects, if the holes are not closed with some substance which the insects will not touch; and of course it is easier to stop one hole than two. 


$$
\text { BIRDS' NESTS. }
$$

\section{CHAPTER II.}

SHould this little book fall into the hands of any boy who has been in the habit of birds'nesting in the manner in which that cruel sport is usually practised, I beg him to listen to a few words of advice. If he be naturally and resolutely cruel, I know they will be without effect, so I shall not urge them on him. But if he has pursued the sport out of mere thoughtlessness, or because his companions have prevailed on him to join them, or because he is fond of rambling about in the fields and woods, and wants an object; or if he wishes to make a collection of eggs, as being very beautiful things; or if, finally, he wishes to observe the various instincts of birds in selecting materials for their nests, their skill as architects, and their cunning in choosing places where to build them; if, in a word, he follows up the pursuit as a branch of Natural 
History, -in either of these cases I am inclined to hope he will see that my object is to give his taste a right direction, and to lay before him a few hints which will make the amusement or study, as the case may be, far more interesting to him than it ever was before.

I have read in one of our standard works on Ornithology, an account of an expedition undertaken by several keen naturalists in quest of the eggs of a certain bird, of which they were very desirous to obtain specimens for their collection. After a journey of very many miles, and a diligent search in the place which the bird was said to frequent, they succeeded in finding a single nest containing only a young bird and one egg on the point of being hatched. They consulted as to what they should do. It would be a great pity, they thought, for the poor little bird to know nothing of life, but a few moments of pain; and yet, having travelled so far in quest of the egg, they were loath to leave it behind them. 
The result was, that one of them, with great care and skill, made an opening in the shell with a lancet without destroying the egg, and without so much as pricking the unfledged inmate, which dropped gently to the bottom of the nest, and, as if to assure them of its sense of their kind consideration, immediately opened its mouth for food. Now one can well believe that those naturalists had not suffered their love of science to blunt their feelings of humanity; yet they were as ardent as the most thoughtless schoolboy; and one of their number is the author of the best book we have on British birds' eggs.* It is clear, then, that one may be a keen hunter after birds' nests, and withal be most humane. This I wanted to show first, for if the pursuit were essentially and necessarily a cruel one, I could, of course, only mention it to give it an unqualified condemnation.

My first words of advice then are,-make * Hewitson. 
a firm resolution to do nothing that your conscience tells you is cruel, either by destroying a nest, robbing it of its contents, or ill-treating the young birds.

In the second place, supposing that your object is to collect as many varieties as possible of each kind of egg; you will attain this, not by cruelly carrying off all the contents of every nest that you may find, but by selecting from each any one egg that differs materially from the specimens you already have. You may thus go on continually adding to your collection, and yet keep it within reasonable limits.

Again, you will frequently find eggs, which no plates or written descriptions will enable you to name with certainty. It is absolutely necessary that you should see the old hird either sitting on them, or leaving them. If you find a nest of such eggs, and take them all away, you deprive yourself of all chance of learning what they are; but if you take one 
or two only, the parent bird will continue her care of the rest, and you will have opportunities of determining the kind to which they belong. And as unnamed eggs in a collection are comparatively valueless, it will be far better worth your while to take but one, and to come back and watch the old bird, than to take all, and not know what they are.

And if your object be to study the habits of birds generally, you will, by leaving the nest, have the opportunity of observing for yourself how many eggs the bird lays; how long she sits; whether the male bird assists at incubation; whether he sings in the neighbourhood; whether the hen sits close, or is easily scared away; how often and with what the young are fed; whether the old birds leave them to shift for themselves as soon as they have left the nest, or continue to watch them after they are fledged; in short, to take really valuable notes in Natural History.

It would seem then, that, on the score of 
humanity, it is cruel to destroy a nest of eggs; and, as far as science is concerned, it is unwise. The considerate and humane collector will find, at the end of the season, that his museum contains a limited number of eggs, the names of the greater part of which have been verified, and about which he has it in his power to relate many pleasing anecdotes illustrative of Natural History; while the mere robber of nests, who has pursued his sport in the spirit of reckless indifference, may be able to show, indeed, a large array of empty eggshells, but has gained no knowledge, and can add nothing to the general stock of information on subjects connected with Natural History. One is, in short, to a certain extent, a Naturalist; the other, an unfeeling destroyer.

Having thus, I hope, shown that the value of a collection of eggs depends very much on the humanity of the collector, I shall proceed to give a few directions for finding out the 
names of eggs in cases where the finder of the nest has had no opportunity of observing the parent birds. To watch a bird in its nest, to ascertain what it is, and then to examine the nest and its contents, is of course the most satisfactory method of verifying the eggs, and should never be neglected when feasible. Little reference to books is then necessary, except for the purpose of seeing how far the descriptions of others agree with, or vary from, your own observations; for it should be always borne in mind, that in Natural History, one well-ascertained fact, properly authenticated, is worth a whole host of opinions.

If, however, as will very frequently happen, you have no opportunity of determining the species of the old birds, you must confine your attention to the nest and eggs, observing first where the former is built, and of what materials, noticing also its shape, and any peculiarity that may strike you. In the next place, notice the number of the eggs, their 


\section{BIRDS' NESTS.}

size, colour, and markings. On referring to plates and written descriptions, you will, perhaps, be able to ascertain without doubt to what bird the nest belongs; but as this will not always be the case, visit it again and again, and it is most probable that something will occur to help you through your difficulty. But if you remain uncertain to the last, lay your specimen aside, properly marked, until you can obtain the opinion of some more practised collector than yourself. But by all means avoid adding any eggs definitely to your collection with names attached to them, until there is no reasonable doubt as to their identity. It is an understood principle among naturalists, that any departure from this rule is a violation of honesty. Want of skill on your part they will overlook, and gladly set you right, but dishonesty will not only take away from the value of your collection, but damage your own character.

No attempt to classify eggs has, as far as I 
am aware, been attempted. Indeed, a natural arrangement, that is, such an arrangement as would bring together the eggs of birds belonging to the same tribe and family, is impossible; because it frequently happens that birds allied in structure and habits, lay very different eggs-for example, the swallow and housemartin; and again, very dissimilar birds lay eggs which are much alike, as the owl and the wood-pigeon. An artificial arrangement, which might bring together eggs either of the same size, the same shape, or the same colour, would be considered unphilosophical, because it would also associate dissimilar birds. At the risk, however, of incurring the censure of scientific men, (if any such should condescend to read what I have written,) I intend to describe, in separate chapters, those eggs which are most alike, classifying them according to their colour and markings. In doing this, I feel assured that although naturalists may not altogether approve of my system, 
they will at least sanction my motive, which is to persuade collectors of eggs to pursue their amusement as a branch of Natural History, which, by the way, has a name of its own, being termed Oölogy, from the Greek oön, an egg, and logos, a discourse.

In the accompanying plates, the eggs are all of the natural size, and are coloured from well-authenticated specimens. They are arranged in the following divisions :-

1. Uniform white, without spots. Chapter iv.

2. White, spotted with red, brown, or black. Chapter vi.

3. Spotted, on a light ground. Chapter viii.

4. Uniform blue or green, without spots. Chapter x.

5. Blue or green, spotted. Chapter xii.

6. Ground various, marked with spots and irregular lines. Chapter xiv.

7. Ground various, mottled with green or brown.

Chapter xvi.

8. Various, or not easily reduced to any of the above heads. Chapter xvii. 


\section{CHAPTER III.}

Next morning, the eggs on the breakfasttable reminded Mr. Miller of Henry's question, whether hens were not birds? so he lost no time in explaining to him how there was no cruelty in taking hens' eggs.

"Fowls," he said, "are domestic animals, that is, they have been tamed by man, and are kept by him for his advantage. From having been long in this state, they have lost many of the habits which they had while in a state of nature, and among them that of making nests. They will lay, you know, in a basket or on a heap of straw, or in a mere hole which they have scratched in the ground. But still their instinct teaches them to lay the whole of a set. in one place. If an egg, or a piece of chalk cut into the shape of an egg, be placed in a convenient corner of the poultry-house, it is 
most probable that several hens will choose to lay their eggs with it. Thus they seem not to know when their laying begins; for when a hen sees an egg in a snug corner of the barn, she never seems to doubt that it is her own, and when she comes back next day, does not notice whether some neighbour hen has added annther, or whether her master has taken away all but the nest-egg. When the time for sitting is come, she has no idea of reckoning how many chickens she is likely to hatch, but takes her place, and sits as comfortably on a round lump of chalk, as she would on a whole nest of real eggs. It often happens that other hens come and lay where she is sitting, and it sometimes occurs that a second hen takes it into her head that she would like to sit in the same place. Then there is a fight for the nest, and the strongest wins it. You see, then, that hens do not know the number of their own eggs; so there can be no cruelty in taking them away. Nor do they mind being disturbed 
when they are sitting; they are so accustomed to man, that you may take a hen off her nest and put her back again, without her seeming to care anything about it.

"But when her eggs are hatched, and she has her brood about her, she is far from being careless then. If a stranger comes into the yard, watch how she calls her little ones around her, and leads them to a place of safety. So tender a mother is she, that our blessed Lord likened her love for her chickens to the love $\mathrm{He}$ Himself bore to the Jews. Whatever change may have come over her by being tamed and kept by man, no change has taken place in her affection for her young. If you meddle with her eggs, she does not trouble herself; but let her see you touch one of her chickens, and then watch her anxiety. She will walk boldly up to you, ruffling her feathers and clucking angrily, as if she meant to make you suffer for meddling with her property. But in spite of all this love and anxiety, she has no 
notion of counting; if a chicken wander so far from her that she cannot hear its cry of distress, she does not seem to miss it, and you may take away several, if you can do so without her seeing you, and she will not find out her loss.

"Many wild birds are like hens in some respects. The night-jar, for instance, lays its eggs on the bare ground, without building any nest. I once had an egg of this bird given me by a man who saw a night-jar alight on a rock, stay there a few minutes, and then fly away. He went up to the place, and found the egg in the very spot where she had been."

"Have you got it now, papa?" said Henry. "No ; I kept it for several years, but not knowing that it ought to be blown, it fell to pieces, and insects destroyed it.

"Most birds," continued Mr. Miller, "sit very closely on their eggs; and though very wild at other seasons, will allow you to come close to them while they are sitting." 
"Oh, yes," said Henry, "I often creep down to the thrush's nest in the laurel-hedge, and watch the old bird. She never flies away, nor even looks at me, but keeps her eyes as steadily fixed as if they were made of glass."

"Just so; and I have heard that some birds will allow you to touch them, but I have never tried this. But some, on the other hand, are very particular. The wood-pigeon, though she builds a very careless nest,- - only a few sticks crossing one another,-is so particular, that if any one touches her eggs, she never sits on them again. Jenny-wren, too, is very jealous of having her house meddled with. If any one puts but a finger into her nest, before she has finished it, she nearly always deserts it; but if she has eggs, or young ones, she is not so particular."

"And do wild birds count their eggs?" asked Henry.

"No, I believe not. As far as I have observed them, they have no idea of number, 
nor can they tell the difference between their own eggs and those of another bird. If you find a thrush's nest, for instance, with one egg in it, and take that one away, supplying its place by a smooth oval pebble or a marble, of about the same size, the bird will go on laying its proper number, as if all were right. And if you put that egg into another thrush's nest, the second bird will not lay one less than its proper number. On the other hand, if you find a nest with four or five eggs in it, and take one away, the bird will go on sitting, as if nothing had happened.

"Now, as you are fond of collecting curious things for your museum, you will like, I dare say, to have a specimen of each kind of egg; and I will tell you how we shall be able to get them in such a way that the birds shall know nothing about it. When we find a nest with four or five eggs in it, we will take only one; and if we find a nest with but one egg, we will either wait till there are some more, or take 
that one, and leave a round pebble in its place. Most people think it impossible to make a collection of eggs without cruelty; but we shall be able to show them that it may be done with as little cruelty as taking the eggs from the poultry yard."

"Oh yes, papa; I will run out into the garden, and take an egg out of every nest; and I have a bag of marbles which will do famously to put into the nests instead."

"Stop a bit, if you please," said Mr.Miller; "I do not mean to have any of the nests in the garden touched; in the first place, because, by coming so near the house, the birds seem to have asked for hospitality, and I think that it would be unfair to impose upon them; and, secondly, I wish to have as many birds as possible near the house; for although the old birds do not sing after they have reared their broods, and the young ones not till the following spring, they make the place cheerful, if it is only by their flying and hopping about." 
"Except the bullfinches, I suppose," said Henry, "who in the winter ate off all the buds from the gooseberry-bushes."

"No, not excepting even the bullfinches. It is quite true that, in the winter, a single bullfinch destroyed at a single meal as many buds as would have produced a gallon of gooseberries, and I ordered them to be shot then; their food now is principally insects and seeds, so that they make some amends for the mischief they did in the winter. They only came into the garden, recollect, during the very cold weather, when the ground was frozen so hard that they could pick up no seeds. Next year, perhaps, we shall have a milder winter; and besides that, I intend to take more pains to frighten them away. But I have no objection to your looking at the nests in the garden, and examining the eggs while the old birds are away, in order that we may know them again when we find them in other places."

The thrush's nest was first examined. The 
old bird was not in the nest, so that there was no fear of giving her any alarm. It was built in a thick laurel-hedge about four feet from the ground, and was made of small twigs, roots, and moss, and plastered on the inside with mud made as smooth as if the clever bird had patted it down with a spoon. There were four bright greenish-blue eggs in it, spotted with black. The old bird had been sitting on them about a fortnight, and Mr. Miller said that they would be hatched in a day or two. There was a wall covered with ivy between the kitchen-garden and flower-garden; in this a bullfinch had built its nest, so safely placed among the stalks and leaves that neither wind nor rain could touch it. The bird had laid three eggs in it, but had not yet begun to sit. They were very light blue, beautifully speckled with purple. Mr. Miller hoped the gardener would not find this nest, for if he did he would be sure to destroy it. "He is so vexed at having all the flower-buds of the gooseberries eaten, 
that in this case he will be very loath to obey my order to take no nests. He has remarked that these birds attack only the flower-buds, and this, he thinks, makes the matter worse; but he is wrong there, for if the leaf-buds were picked off as well, not only would the fruit be lost, but the trees would be injured; but as it is, if we lose the fruit this summer, we shall probably have a double crop next year."

As they approached the shrubbery, a loud, harsh, frequently repeated note was heard, and a blackbird darted away from a hedge of brambles, flew along close to the ground on the other side of the hedge for some distance, and then crossed the field towards a thick wood which lay beyond the meadow. "No doubt," said Mr. Miller, "there is a blackbird's nest in that hedge ;" and, sure enough, one there was, built of small sticks and roots like the thrush's, but lined with moss instead of mud. There were four or five young ones in it, who all opened their ugly yellow mouths as 
Henry looked in, each supposing, perhaps, that it was his turn to have a delicate snail or fine fat caterpillar for breakfast.

Just outside the dining-room window was a laurel-tree, one long stiff branch of which came close to the glass. On the top of this a pair of chaffinches had built their nest. There were very few leaves on the branch, and there was some one or other passing beneath at all hours of the day; but the pretty birds seemed to think that so close to the house as this, no one would be so inhospitable as to hurt them. And they were right. No one ever looked into the nest. You might see the tail of the hen-bird stretching out over the edge all the while the sitting was going on ; and the cockbird frequently perched on the acacia-tree a few yards off, singing his short merry song, which sounded as if he said, "I'm-come-downthis-fine-morning-to-pick-up-a-few-grains-ofwheat-o." No one doubted that there were eggs in the nest, and that they were hatched; 


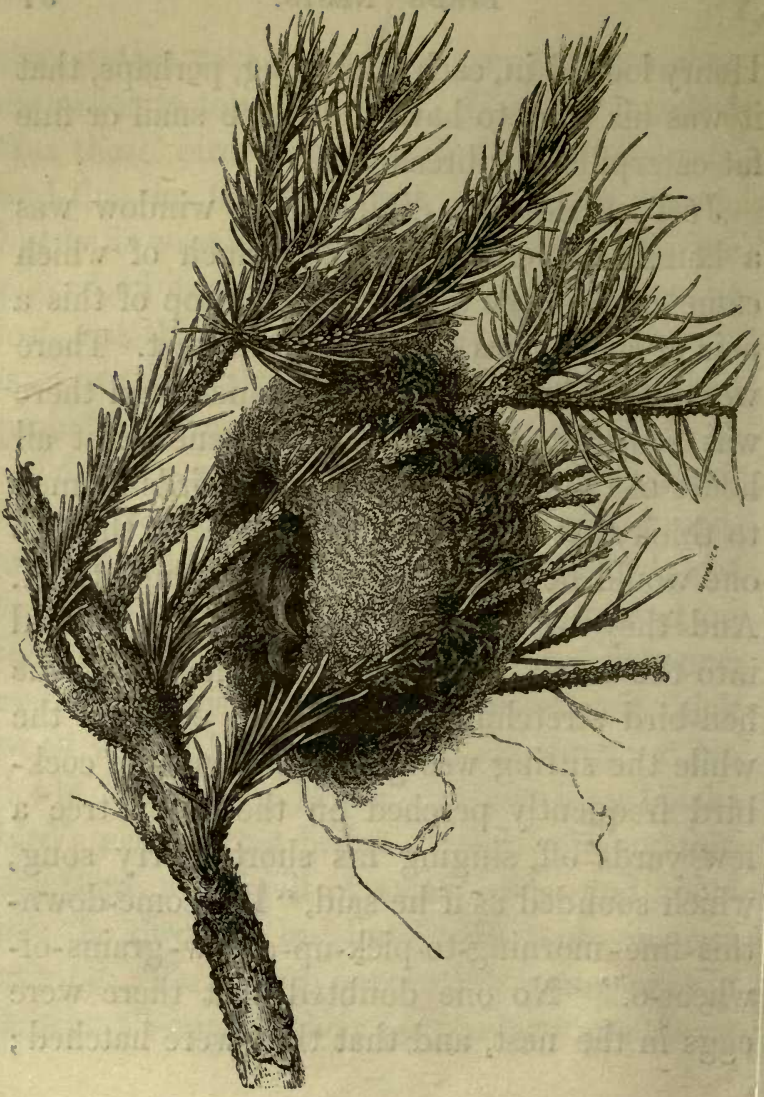


for after a time the hen-bird left off sitting so constantly, and was seen more frequently picking up the crumbs that were thrown out from the breakfast-table.

Nearly opposite the front door was a Norway spruce-fir, about as high as the house, with long drooping branches. Half-way up, and near the end of one of these branches, was a round ball of moss, which was supposed to be a golden-crested wren's nest, because a pair of those birds were often seen in the tree climbing and hopping about quite fearlessly, twittering to one another, and chirping out their short, thin song. Soon afterwards, one only was seen; and at last no doubt was left about the matter, for from one of the upper windows, the old birds could be distinctly seen feeding their young. He must have had a hard heart, who would have interfered with the happiness of these pretty little birds.

Greenfinches were very abundant here, as they are in most places. They built their nests 
in bushes ten or twelve feet from the ground, of small twigs, moss, and wool. Their eggs were white, or nearly so, with reddish-purple spots about the larger end. The cock-bird used to perch during great part of the day, especially when it was very warm, on a branch of a tree hard by, repeating over and over one long note, that sounded more like a croak than a chirp. No one thought it a pleasant sound, except, I suppose, Mrs. Greenfinch, who being obliged to stay at home all day long, thought any note musical which told her that her husband was keeping watch not far off.

In a little wood adjoining the garden was a fine old oak-tree, all the lower part of which was thickly clothed with ivy. Among the stems of this, two wrens had built their comfortable nest. The entrance was made of moss, twigs, and dry leaves, and shaped not like a cup, as many other nests are, but round like a ball, with a small hole in front. So cleverly was the nest hid, however, that you 
could not see it without bending back the leaves, one of which hung down directly in front of the opening. They did not visit it to-day, because Mr. Miller said that the wren very often deserted her nest if she was disturbed.

This part of the wood was very thick with brambles and thorns, and Mr. Miller thought there was a nightingale's nest somewhere near; for one of these sweet birds was nearly always, except during the heat of the day, to be heard pouring out his melody from one or other of the trees hard by. In the early part of the evening too he was silent, but after the sun was gone down, when the blackbird and thrush had piped their last song, and the woods had become so still that one would have thought every note of music over for the night, all on a sudden his clear rapid strain burst forth from the thicket, and was pretty sure to be answered by some rival songster from the adjoining copse. At what time he 
fed and took his rest it was hard to say; for he seemed too fond of music to leave time for either. Where his nest was, no one could tell; the bushes were so thick that it was impossible to search them, and Mr. Miller was very glad of that, fearing that if any one found the nest, the birds would fly away to some other place, and so he should lose their song.

A little further on, near the top of a low oak-tree, covered with ivy, was a large nest, to which Mr. Miller climbed up, and found it to be a jay's nest. The outside was of sticks, and the inside of small roots matted together very closely, and it contained five eggs of a dull greenish colour, speckled all over with light brown. One of these was taken to add to the collection.

On the ground, in the midst of a tuft of brambles, a pheasant had built her nest. It was so close to the path, that from it the patient bird could be seen sitting on her eggs. Mr. Miller never went near it, for fear that the 
bird should get into the habit of flying from her nest when any one came near her. In this case he thought it very likely, that if any mischievous person came near the nest, the bird would fly away, and thus point out the place where she had left her eggs. Henry wished very much to have one of these, but Mr. Miller would not allow him on any account. Pheasants, he said, were among the birds which are called game, and it was unlawful to take their eggs, or even to shoot the birds themselves, except during the winter. Many persons collect the eggs of pheasants, and place them under hens in their poultry-yards, to be hatched there, because the old birds are liable to be caught, and the eggs destroyed by foxes. He said, however, that he should not do this, as the young birds were difficult to be reared, requiring much care, and different food from that given to poultry. As it happened, it would have been better if he had done so. 
"I hope," said Henry, "the old bird will rear these safely. Do you recollect, papa, what happened to the young pheasant in the hay-field last year ?"

Mr. Miller recollected it well : one of the mowers, while cutting the hay with his scythe, accidentally killed a young pheasant, which with its brothers and sisters was hiding among the thick grass. The man was very sorry to have done this mischief, but took care that the rest of the brood should get off safely. As the mowers went on with their work, the terrified little creatures advanced further and further into the long grass, and were at last driven into the wood, where no doubt they were soon found by their mother.

There were several other nests in the wood, but none of these were visited, except a thrush's nest; which was built against a dry hedge, and sheltered by the roots of some trees which grew above. The bird cared so little for visitors, that Mr. Miller and Henry went within 
a few feet of her, without frightening her from her post.

As they were returning, the gardener met them, and having answered some of Mr. Miller's questions about his potatoes and other crops, added-

"If you please, Sir, may I destroy the starlings' nests about the house?"

"Why do you wish them destroyed?" said Mr. Miller.

"Because, Sir, one has been built at the top of the pipe which drains the roof of the house; and if it is allowed to stay there, and we have a shower of rain, the shoot will overflow, and the water will soak through the walls. The same thing happened last year, and the plastering of one of the rooms had to be taken down."

"Well, George, you know I do not like the nests to be meddled with, which are built about the house and garden; but if these birds are positively doing mischief, I am afraid I 
cannot say no. As long as they want shelter only, they shall have it; but if they choose to build their houses so as to injure mine,-and I have the greatest right to be comfortable here, since the house was built before the nest, - the poor birds must be turned out. But why did you not frighten them away before the nest was finished? They would then only have had to look out for another spot."

"Why, Sir, I did all I could. I never saw them without shouting to them, and clapping my hands at them; but they did not mind me a bit; for as soon as my back was turned they were at work again. I even tied two long sticks together, and poked out some of the rubbish they had brought there, but it was of no use. They seemed so fond of the place, that nothing would drive them away."

A long ladder was soon placed against the house, on which George mounted, and presently came down, bringing with him four eggs of a delicate pale-green colour, without 
spots. These were placed in Henry's hands, and greatly admired. A second journey was made to the top of the house, and George threw down an immense quantity of twigs, roots, straw, and hay, which it must have cost the poor birds very much pains to have collected one by one.

Gardeners seem to have a hatred of nearly all birds, thinking that they resort to gardens only for the sake of picking off buds, destroying fruit, and gathering up seeds which have been sown. George therefore wanted to pull out another starling's nest, which had been built in the ivy under the shoot, as well as all the sparrows' nests he could find; but Mr. Miller, seeing that these did no injury to the house, would not allow any more to be touched. "I am afraid I shall never be able to convince you," said he to George, "that it is only during a very short portion of the year that the birds do us any mischief. We ought then to be on the watch and drive them 
away; but at the season when th

live on insects, that is, at the seas

have their young, we ought to be glad to have them. Starlings never do us any mischief, except when our cherries are ripe-when they certainly help themselves very freely if we allow them. But all the rest of the year they live on snails, caterpillars, and grubs, which are mischievous nearly all the year round, especially when plants are growing, and want all the leaves they can put forth. Sparrows, I allow, eat a great deal of corn both at harvest and sowing-time; but I doubt whether they do not destroy wire-worms and other mischievous insects, more than enough to make up for the damage they do to the grain. No, no ; let them alone : they are merry little fellows, and shall have shelter in my ivy, even if no one else has a word to say for them. But while you have the ladder here, you may stop up with mortar the hole where the hornets had their nest last year." 
Hornets are very large flies, with four wings, and bodies banded with yellow and black. They are not so troublesome as wasps, as they do not often come into houses and fly about meat and fruit as those annoying insects do, but their sting is much more painful than that of the wasp. The year before, some hornets had found their way through a hole between the chimney and tiles, into the space between the rafters and ceiling of one of the bedrooms. There they had built their nest. In doing so, it seemed that they had done some damage to the roof, perhaps, by eating away the wood of the roof, and thus letting in the rain; for one day in the summer, after heavy rain, a large brown spot appeared in the ceiling of the bed-room, and it was feared that the plaster would fall. Attempts had been made to drive them out, by blowing the smoke of burning sulphur into the hole; but the nest was too far in to be reached. To take down the ceiling would have made the matter 
worse, for the hornets would then have been able to get into the room; and though they rarely sting any one unless provoked, they are likely to become entangled in people's dresses, or to crawl into corners, where one may lay one's hand on them by accident, and thus be stung before the danger is seen. Hornets live principally on flies ; and in some parts of North America, farmers are in the habit of hanging up their nests in their houses, in order that they may drive away the flies, which they do without injuring any one. Mr. Miller however thought, and so I suppose would most other people, that the flies were the less evil of the two.

All this time Henry was very anxious to blow his eggs, in order to place them in his museum; so, when the hornets' hole was stopped up, Mr. Miller cut off a piece about six inches long from a tall stem of grass he had brought from the wood, and having made a hole in the egg rather nearer the small end 
than the large, showed him how to hold the egg between his finger and thumb on a level with his eyes, and then, carefully putting in the straw, to blow gently. The first attempt was unsuccessful, for holding it too tightly, it broke and fell to the ground, but the others were done very well, and taken into the house. Eggs are less liable to be broken when blown than when they are not, because, being then empty, they are so light as to bear a short fall; but still they require great caution in handling; and as Henry was only allowed to have a museum on condition that everything in it was kept in excellent order, and properly taken care of, he followed a plan in keeping them which his father taught him, and which he found a very good one. It was ás follows:

He divided a sheet of cardboard into pieces of equal size, each measuring about two inches long and an inch and a half wide. A line was then ruled with a lead pencil, about the third of an inch from one of the long sides. Along 
52 BIRDS' NESTS.

the line thus made, the point of a sharp penknife was drawn, just heavily enough to cut half way through the card. This made it very easy to turn up a border, which served two purposes - first, to take up the card; and, secondly, to write the name of a bird on. The eggs, as soon as they were blown, were laid in a warm place to dry, care being taken that they should neither roll away nor be blown away, and that the hole should be upwards. When they were thoroughly dry, the name of the egg was written on the border of the card, and the egg itself fastened with gum or paste, or, best of all, with India-rubber glue, to the card, in such a way that the hole rested on the card. If the egg happened to have a large hole in it, a small piece of thin paper was glued over the opening to keep out insects. Large eggs were fastened on singly, one on a card; small ones in pairs; and by the side of each egg was written a number corresponding to a similar number in a memorandum book, in 
which was written down a statement of the day, year, and place, when and where it was found, together with a short description of the nest, and anything else worth noticing. The cards, with the eggs in them, were then laid in rows in the drawers of a cabinet, so that they might always be kept from light, which would destroy their colour.

Before the end of the summer, there were between twenty and thirty kinds of eggs in the collection; but, among them all, there was not one the loss of which occasioned pain to the parent birds, with the exception of the starling's eggs, and some few others taken from nests which the persons who found them were obliged to destroy in the course of their work.

Persons to whom the collection was shown admired it very much, but generally asked if it was not cruel to rob so many birds' nests. When, however, they heard that not a single nest had been wilfully destroyed, nor an egg 
taken with the knowledge of the parent birds, they altered their minds, and thought that a knowledge of birds' eggs - thus made a branch of Natural History, and studied in such a way as to avoid the least approach to cruelty - was not only harmless in itself, but might teach young persons to be considerate in all their dealings with others. Mr. Miller, too, was of opinion that if a boy, in spite of his eagerness after birds' nests, could be taught to deny himself the possession of an egg altogether, if he could not obtain it without being cruel, he was actually learning a lesson in humanity.

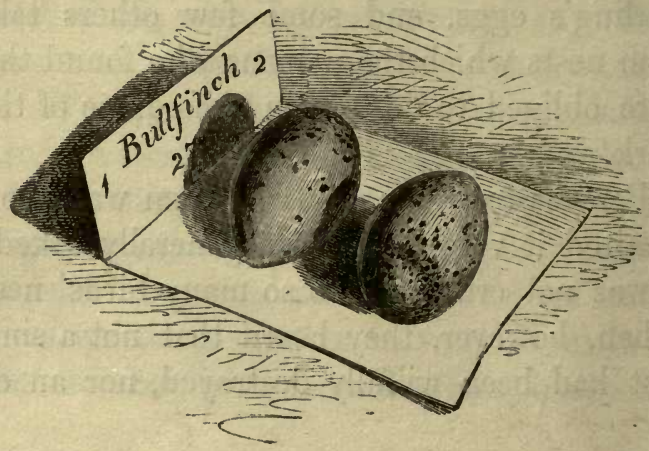




$$
\text { es }
$$





\section{CHAPTER IV.}

EGGS WHITE, WITHOUT sPoTS.

\section{The Barn OwL.-Strix flammea.}

\section{Plate I. Fig. 5.}

THIs bird builds its nest-or rather lays its eggs, for the nest is a very simple structurein barns, churches, ruins of all kinds, and in hollow trees. Its eggs, which are from four to six in number, are pure white, about an inch and a half long, or rather more, and are much rounded at the smaller end. It has been observed, that the nest of this bird sometimes contains eggs and young birds at the same time; and one instance in particular has been noticed of a nest which contained two eggs, and when these were hatched, two more were laid, which latter were probably hatched by the warmth of the young birds; a third laying taking place after the latter were hatched; and the nest at 
last contained six young owls of three different ages, all of which were reared. (Fig. 1.) The eggs of the Tawny Owl, Syrnium stridula, are usually laid in a hole of a tree. They are larger than those of the Barn Owl, and are generally three or four in number. After the young have left the nest, they perch among the branches of the tree near the nest, where the parent birds still continue to feed them. They are easily reared by hand, and if, when thoroughly fledged, they are allowed to have their liberty, they rarely fail to frequent the place where they were brought up.

\section{Wood-Pigeon or Ring Dove.-Columba Palumbus.}

The Wood-Pigeon builds its nest of a few sticks, loosely put together, on the stout branch of a tree, a spreading. bough, the fork of a fir or other tree, or on a massive bunch of ivy, usually not less than fifteen feet from the 


\section{BIRDS' NESTS.}

ground. It lays two white eggs, of about the same size as those of the white owl, but longer in proportion to the breadth. The old birds are very shy, and usually desert the nest if any one touches their eggs, though far from being so particular if their young are hatched. The Stock Dove, Columba Enas, builds in the hollows of pollard-trees, and lays two eggs, smaller than those of the last. The turtle Dove, Columba Turtur, builds a nest similar in character to that of the wood-pigeon, and in like situations. It also lays two eggs, which may easily be distinguished by their very much smaller size.

Green Woodpecker.-Picus viridis. Plate I. Fig. 3.

There are four kinds of British woodpecker, one of which, the Great Black Woodpecker, is so rare, that the most eager searcher after birds' nests must not hope to obtain its eggs. The others are less unfrequent; and 
the young oölogist, if he lives in a woodland district, and is skilful in swarming a tree, stands a fair chance of making a prize of some of them. The Green Woodpecker, Picus viridis, the largest of the three, hollows out for itself a hole in the trunk of an ash or elm, always choosing, it is said, a spot in which there are symptoms of incipient decay. This statement, however, requires confirmation. It constructs no nest, but lays its eggs on some of the chips which it has torn off in the course of its operations. As if afraid lest, by scattering at the foot of the tree the fragments of wood removed during its excavations, it should betray its haunts, it has the credit of carrying them away to a distance. It lays from five to seven eggs, smooth, shining, and pure white, and about an inch and a quarter in length. As it belongs to the order of Climbers, the young birds show their natural propensity at a very early age, climbing about the trunk of the tree before they are able to fly. 
The Great Spotted Woodpecker, Picus major, resembles the preceding in habits, and its eggs, which are also white, and about five in number, are an inch long. The female bird exhibits great attachment to her eggs. Montagu mentions an instance where, "notwithstanding a chisel and mallet were used to enlarge the hole, the female did not attempt to fly out till the hand was introduced, when she quitted the tree at another opening. The eggs were deposited two feet below the opening, on the decayed wood, without the smallest appearance of a nest."

The Lesser Spotted Woodpecker, Picus minor, also lays its eggs in a hole in a tree, choosing one which has a small opening, evidently for the sake of security. The number of its eggs is generally five, and they are about three-quarters of an inch in length, very smooth, and of so delicate a structure that, though of a pure white when blown, they are of a light flesh-colour before the yolk is removed. 


\section{Wryneck. - Yunx Torquilla.}

THIs beautifully marked bird, popularly known as the Cuckoo's Mate, because it appears and departs about the same period with that bird, is closely allied with the woodpeckers in structure, and deposits its eggs in similar places, constructing no nest, though it does not object to make use of one which has been deserted by another bird. The eggs are from six to nine or ten in number, white, smooth, and shining, resembling, in every respect, those of the lesser spotted woodpecker. The wryneck, after it has once selected a hole for its eggs, becomes so attached to it, that no trifling annoyance will drive it away, and has been even known to haunt the same tree after its eggs have been several times removed.

\section{Hen-Harrier.-Circus cyancus.}

The Hen-Harrier is a bird of by no means common occurrence, and is generally found in 
marshy districts, especially Cambridgeshire. Its nest is composed of small sticks and coarse grass, with a very slender lining. In a level country, it commonly chooses a tuft of furze, or some other low bush; but in hilly districts it not unfrequently places its nest on the bare ground. The eggs vary from three to five, and are most frequently of a bluish white, though occasionally they are marked with light spots of yellowish brown.

\section{Marsh HaRRIER.-Circus aruginosus.}

This bird, as its name implies, frequents the same districts as the last, but is even less common. Its nest, which is placed on the ground among short wood, furze, or fern, is composed of sticks, rushes, and short grass, often used in such profusion, that the top of the nest is a foot or more from the ground. Sometimes, though rarely, it builds in the fork of a large tree. The eggs closely resemble 

62
BIRDS' NESTS.

those of the hen-harrier. The nest and eggs of the Circus cineraceus are smaller than those of the last, but very similar. The eggs of all three species may readily be distinguished from other white eggs, by a fine greenish blue tint on the inside, which is most evident when the egg is held up to the light.

\section{Water Odzel.-Cinclus aquaticus.}

\section{HAVE never had the pleasure of seeing the} nest of this bird, which is said to be very beautiful. Neither nest nor bird is likely to be confounded with any other. The latter, a bright, active, cheerful warbler, I have many a time watched with admiration alight on a mossy island of stone, round which the sparkling waters of a mountain streamlet have dashed in some wild ravine, far away from the haunts of men. Glad should I have been to follow him to his mossy home; but no, off he flies, dashes into the clear water, and is gone where nothing but a bird can follow him. 
His nest is not far off, no doubt concealed with his usual art, under one of the projecting stones that line the rocky bank of the stream, perhaps behind the crystal sheet that shoots from yon noisy waterfall. There, surrounded by water, and enveloped in a perpetual mist, the water ouzel has established his warm and comfortable nest,-a mass of closely interwoven moss, seven or eight inches deep, ten or twelve inches in diameter, with a hollow chamber in the centre, lined with a few dry leaves. One might almost suppose that he had turned a wren out of doors, and adapted her house to his own dimensions. The eggs are somewhat pointed at the smaller end, rather smaller than those of the thrush, and pure white.

\section{Kingfisher. - Alcedo Ispida. Plate I. Fig. 2.}

The nest of the Kingfisher was the subject of a pleasant fable among the ancients. Con- 
structed of some waterproof material, it was said to be buoyed up by the waves, to be drifted to and fro by the ocean currents, and to have the wondrous property of creating a calm to a considerable distance around it. Halcyon days we read of still, though it is not every one, perhaps, who is aware that the term is borrowed from this beautiful little bird. Some modern naturalists, too, have told pretty stories about the kingfisher's nest; they do not, indeed, direct us to search for it in the centre of a calm spot in the ocean, but describe it as wrought together of pearly fishbones, interwoven with a skill little short of miraculous. The truth, however, seems to be, that the fabled bird, though prince of fishermen, is but an indifferent architect, laying its eggs on a mass of half-digested fish-bones, and other refuse, placed at the extremity of a deep hole, which slopes upwards from the face of a bank. It is even doubtful whether this hole is excavated by itself, or is not rather the 
deserted habitation of a water-rat or sandmartin. It usually lays six or seven eggs, which are nearly orbicular, of a uniform white tinged with the most delicate green,

\section{SwIFT.-Cypselus Apus.}

Naturalists have given to this bird the specific name Apus (footless); and, indeed, its legs are so short, that were it to alight on the ground, it would be totally unable to raise itself so as to take flight again. Consequently, it has little power of collecting materials for building. Some ornithologists state that it gathers the materials of its nest while on the wing; others, with more show of reason, state that it universally occupies the deserted nest of a house-sparrow, selecting one which has been placed in the wall of a church, or some other elevated building. When it has once established itself, it usually retains its habitation for many years, which, as it is never 
repaired, in process of time acquires a flattened form, and has the appearance of having been cemented together by the art of the bird. It usually lays two eggs, an inch long, and of a pure, spotless white. If these are taken or destroyed, their place is supplied by another pair, but only a single brood is reared in a season.

\section{House Martin.-Hirundo urbica.}

\section{Plate I. Fig. 1.}

TнE famous lexicographer, Dr. Johnson, who loved brick walls far more than grassy banks, is reported to have addressed some birds which he observed in a wild district of Scotland, with the exclamation, "What, have wings and stay here!" The city doctor probably placed the house martin as first among the philosophers of the feathered tribe, for rarely is it seen at any distance from the haunts of men, and still more unfrequently does it place its nest away from the friendly 
shelter of a human habitation. We have not space to repeat a tenth part of all the interesting facts which have been recorded about the architectural skill of this universal favourite, of its wanderings to sunny lands, or of the wonderful constancy with which it returns, year after year, to the same spot, or of the perseverance with which it adheres to its original habitation, notwithstanding the repeated heartless efforts made to dislodge it. Better adapted by its nature for perching on the ground than the swift, it may often be seen in summer by the edge of some road-side pond, picking up particles of mud, which it tempers with some natural secretion, and attaches to the wall of a house, preferring the corner of a window, and always building from the bottom upwards. It lines the inside with straws and broken stems of grass, and finishes off with a layer of wool, hair, feathers, and any other soft materials which it may chance to find near the dwellings of men. The eggs, four 


\section{BIRUS' NESTS.}

or five in number, are of a long oval form, rather pointed, and about three quarters of an inch long; their colour is pure, spotless white.

\section{Sand Martin.-Hirundo riparia.}

THE Sand or Bank Martin derives its name from the place which it selects for building its nest. Many interesting accounts have been written of its skill as an excavator, the most. pleasing of which, perhaps, is that of Mr. Robert Dick Duncan. He says, "It is extremely pleasant to observe the process of burrowing; and it is by no means difficult to enjoy a view of their operations. Taking with me a small telescope, I seated myself at a little distance, on the opposite bank of the river, early on a warm morning in May. The swallows, no way molested by my presence, continued at intervals to excavate their nests. Grasping the perpendicular surface of the bank with their claws, and steadying themselves by means of their tails, they commenced working 
by picking a small hole with their bills. This hole they gradually enlarged by moving round and round, and edging off the sand with the side of their bills, which they kept shut. Their progress at first was slow, but after they had obtained room to stand in the excavation, they proceeded very rapidly, working within with their bills, and carefully pushing out the loosened sand with their feet. At one time the male, at another the female, was the excavator. When their burrowing was impeded by the resistance of a stone, or any other obstruction, if unsuccessful in their efforts to remove it, they left the cell, and commenced digging a new one. They engaged in these exercises only for a short time each morning, as they abandoned themselves to enjoyment throughout the day. The nests were deposited at the ends of the cells, the depth and direction of which varied much. Some extended three feet, others not more than six inches; some were horizontal, some 
descended nearly perpendicularly for a little, and then rose again; while others turned in many directions. In all, however, the nest was a little elevated above the entrance of the cell, no doubt to get rid of moisture. The materials of the nest were uniformly a few straws of hay, and many whitish feathers. The number of eggs usually found in each nest was six. They are small, of a snow-white colour, tinged with a sulphureous yellow when newly laid. This tinge disappears when the eggs are blown, and arises from the yolk shining through the shell, which is of a very fine, thin texture. Of all our swallows, these seem to be the most social, nestling in numerous communities, and often within a few inches of each other.

\section{Lesser Grebe or Dabchick.-Podiceps minor. Plate I. Fig. 4.}

Though this amusing little diver is common enough in our lakes and larger rivers, its nest 
is by no means of frequent occurrence; not that there is any doubt of its breeding habitually with us, but that it is usually placed in situations which are difficult of access. It chooses the side of a lake or river, where, among reeds, flags, and other tall aquatic plants, it constructs a rather large nest, if not actually on the surface of the water, yet not much raised above it. The nest itself is composed of soft green water-weeds and mosses, mixed with slime. The eggs are from four to six, about an inch and a half long, of a chalky white when first laid, but soon becoming discoloured by the substance of the nest, and the soiled feet of the parent bird. Their shape is peculiar, as they are nearly equally pointed at both ends. When the parent bird quits them in search of food, she invariably covers them with part of the materials of the nest, whether for the purpose of hiding them, or of retaining their heat, it is hard to say. However this may be, so effectually are they concealed, that 
unless the bird be seen to leave her nest, the latter is rarely discovered, except by pulling into the shore the masses of weeds which abound in such localities. 
BIRDS' NESTS.

\section{CHAPTER V.}

THE starling's nest was destroyed in good time, for the next day it rained very heavily, and on the day following there was but little improvement in the weather. Even if it had not been pulled out by the gardener, it could have scarcely been used again by the birds, so thoroughly was it soaked with water.

The chaffinch sat steadily on, just outside the dining-room window, and continued, in spite of the pouring rain, to keep her eggs dry. Whether she ever left her nest to feed, could not be found out. Henry often went to the window to see, and there was always the same tail projecting over the side of the nest. The same tail at least it appeared to be; but perhaps the cock-bird sometimes took his wife's place, in order that she might go and look for a dinner,-or perhaps he brought her food. 
She had not far to go, for, every day, crumbs of bread and scraps of meat were scattered in the path, which seldom stayed there long. The chaffinches, however, were not the only birds who came for these. A pair of robins were constant visitors, and so was a coletit. The robins were pronounced to be very quarrelsome birds, because even when they had had as much as they wanted, they often drove away any other birds which came down for a share. The tit was a very funny fellow; he was particularly fond of picking a bone, standing on it in all possible attitudes, jerking about and twisting his head from side to side, picking at little bits of gristle, and poking his short beak into holes in the oddest manner that can be conceived.

None of them ever seemed to get wet, and Henry supposed that they kept moving about, and fluttered with their wings, to shake off the drops; but he fancied that the chaffinch, who sat all day without moving, must be very wet 
and uncomfortable. But Mr. Miller reminded him of the way in which ducks dip their heads and necks under water, and let the round drops run down their backs like quicksilver. "While birds are alive," he said, "they can bear being exposed to a great deal of rain without getting very wet; and besides this, they are so thoroughly thatched with feathers, that even if the outer ones got wet, the soft down beneath kept them warm and dry. But even if the rain wetted them, we ought not to take it for granted that they are then as uncomfortable as we should be if we were to sit still in wet clothes for a whole day. We ought not to doubt that the Great Creator of the world has given to all animals the power of enjoying the kind of life which their instinct teaches them to lead. I can quite believe that a wren, sitting motionless in its dark hole of a nest, is all the while enjoying life,-the gift of God,-as much as the lark, lifted up and praising God in the firmament." 
"But I would much rather live in the sky, like the lark, than stay all day long in a dark hole, like the wren."

"Yes, no doubt you would, and so would I, because God has given to us a natural inclination to climb up to high places, eyes that we can only use in the light, and a taste for sweet sounds; but other creatures-a mole, for instance-would not be so happy among the clouds as when employed in hunting for worms in his underground galleries. Last summer, you thought the dabchick's life must be a pleasant one, because he spent the whole of his time paddling about in the cool water, and diving among the water-lilies. You would have thought differently had the weather been cold, and the river fringed with ice; but he, I doubt not, enjoyed himself equally at both seasons. Either his feathers kept him warm, or if the cold pierced through his velvety coat, it was pleasant to him. You may see herons, in the coldest weather, standing up to their 
knees in water, and, like your thrush, as still as if they were stuffed; but you must not suppose that they suffer from the cold as much as we should if we were to take their place. It does not follow, you see, that what you think unpleasant and comfortless, is so in reality to the animals to whom God has given a nature different from yours. There is a bird in the Arctic regions, which has been seen flying about and perching on crags of ice which never melt, where there are no fields to be green with grass, and there are no living things but itself; where the tops of the rocks are covered with snow, and if sometimes the face of a cliff is uncovered, it bears no vegetation, but a lichen so thin that you could scarcely scrape it from the rock with a knife. A dismal region, indeed, we should think it ; but do you suppose that the snow-bunting would stay there if it suffered as much from cold as we do? No; since it has the power of flying, it would use its wings to some purpose, and seek 
another climate that suited it better. Every bird-nay every insect-may teach us a useful lesson, namely, to think that the happiest lot in life is the one which God has assigned to ourselves : that is the real way to be content." "And does the snow-bunting stay in the Arctic regions all the year round?"

"No," said Mr. Miller, " though it has often been seen flying about far within the line of never-melting ice, it obtains its food further to the south, where it builds its nest among loose stones, and in the crevices of rocks. An Arctic voyager,-Captain Lyons, - found a nest of dry grass, neatly lined with deer's hair and a few feathers, in the bosom of the corpse of an Esquimaux child. Captain Parry also found one among some drift timber lying on the beach; it contained four young birds, and though the sailors sat down to breakfast within three or four feet of the nest, the old birds frequently came and fed their little ones with grubs. In the winter, when the country for 
hundreds of miles is covered with deep snow, the snow-bunting travels to less severe climates in quest of food, and is not unfrequent even in England. In Scotland it is yet more common, and is supposed to build its nest near the patches of snow which remain all the year round on the summits of the highest Scottish mountains."

"I suppose I shall never have a snow-bunting's egg," said Henry.

"Well, indeed, I do not think it very likely; but I dare say we shall find, all in good time, nests of the yellow and reed buntings, as they both build in this neighbourhood. And now run and fetch me the third volume of Macgillivray's British Birds, and we will read his description of the way in which a pair of wrens built their "hole of a nest."

"The account is too long to be given here entire; but the substance is as follows: 'Yesterday,' says Mr. Weir, 'a pair of common wrens flew about for a considerable time, in a particular part of my shrubbery, as if in search 
of a proper situation ifor constructing the dwelling which should contain their intended brood. About a quarter past six this morning, they appeared to be engaged in the most serious consultation. They hopped up and down amongst the branches of a Spanish juniper, each of which they surveyed with particular attention. At seven o'clock, in one of its clefts, about two feet from the ground, the female began to lay the foundation with the decayed leaf of a lime-tree. Although two men were at work within seven yards of it, yet she, like a steady and active workman, was so bent upon the completion of her design, that she laboured as if unaware of their presence. Her perseverance was indeed astonishing, for she sometimes carried in bundles of leaves nearly as big as herself. To her beloved partner she seemed to give intense delight, for. he sat upon the branch of a Portugal laurel, a few feet above her, viewing most anxiously her operations; and now and then, having mounted 
to the top of a plane-tree, he poured forth his sweet and powerful song, and continued to do so nearly all day. He gave her but little assistance, thinking, no doubt, that his music was enough to lighten her fatigues, and to support her under them. Between eight and nine she was most actively employed, for during the space of ten minutes, she sometimes carried in four, five, and even six bundles of leaves, about the fitness of which for her purpose she seemed to be very careful-for I observed that, after examining them most carefully, she let drop what did not suit her. After having made the foundation firm, by pressing the leaves with her breast, and turning herself round upon them in all directions, she began to raise its sides. In this operation, however, she was not so expeditious, as she was under the necessity of flying to a greater distance for materials, in the search of which she sometimes remained out eight and ten minutes. From the inside she built the under part of the 
opening with the stalks of leaves, which she fitted together very ingeniously with moss. The upper part was constructed with moss only. To round it and give it the necessary firmness, she pressed it with her breast and wings, and turned her body in different directions. Most wonderful to tell, about seven o'clock in the evening all the outside of the snug little building was finished."

"Mr. Weir was not the kind of person who did things by halves; so, as early as half-past two next morning he was on the watch again. There had been heavy rain during the night, but the nest was already waterproof. At ten minutes past three, the male bird hopped round and round, seemingly much pleased with the progress his busy little wife had made. $\mathrm{He}$ then flew to the top of a tree, and began to pipe his morning song. At half-past three Mrs. Wren went into her nest, and having stayed five minutes to set matters to rights, worked alone till between seven and eight 
o'clock, when her husband came to her help, and both worked pleasantly together until eleven, bringing in and fitting moss. From eleven till a quarter to one they were absent, perhaps taking some refreshment. They then worked again till four, still bringing in fine moss. Between four and five o'clock, Mrs. Wren again worked alone, but not so industriously, as she brought home only three feathers. After the day's work was over, Mr. Weir placed a slender stalk across the opening of the nest, in such a way that the birds could not get in without removing it. This was not gone till half-past eight on the third day. Both birds again worked together till dinner time; but every time the male bird assisted, he flew to the top of the nearest tree, and sung aloud the praises of his industry. At half-past two o'clock the day's work was over. On the fourth day they did not begin to build till nearly nine o'clock, when they went in with fine moss and feathers, about once in a quarter of an hour. 


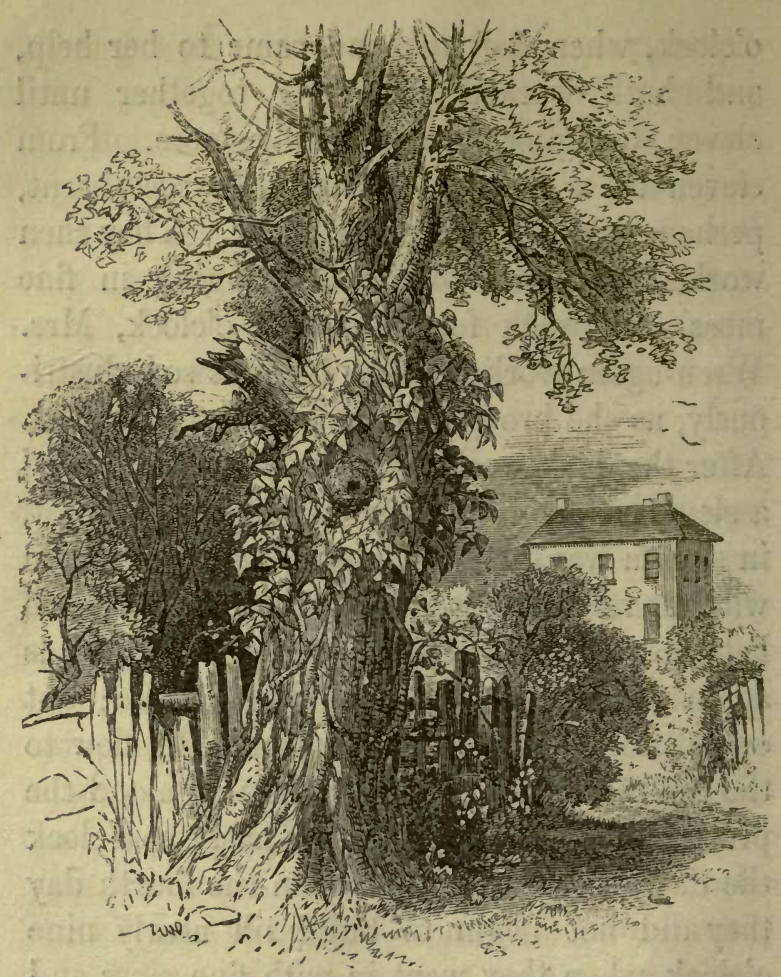

WREN'S NEST. 
“ 'Whilst,' says Mr. Weir, 'I was anxiously watching their motions in the midst of a very thick arbor-vitæ tree, about nine feet from their nest, the female, who was sitting at the door of it, having noticed me, set up her cry of alarm. The male, upon hearing it, appeared to be in a state of great irritation. I immediately ran off to some distance, pursued by the little creatures, who were scolding me with great vehemence. On the fifth day, they gave over working at half-past one. The sixth day was Sunday, when they were not watched. On the seventh day they began to build at twenty minutes to eight o'clock, went to dinner at their usual hour, and brought in only a few feathers in the afternoon. On the eighth and ninth days they worked only till ten o'clock. On the forenoon of the tenth day, the nest was finished. It was by far the neatest of its kind that I have seen; and little wonder, when we consider the long time which they took in the erection of it. I regret to say that it was torn 
down by a cat that frequented the neighbourhood. The female, who had gone into it to lay her first egg, had attrạcted its notice, and had in all probability been devoured, as I never saw her again." "

"Oh, how sorry I am," cried Henry, "to hear the sad ending of that pretty story! I am sure that no one who heard it would ever destroy a wren's nest. I dare say, too, many other birds take just as much pains as wrens do. I never liked cats, and now I shall like them less than ever."

"As for that matter," said Mr. Miller, "I do not see that poor puss is more to be blamed for catching a bird for food than a mouse. If the nest had been torn out by a mischievous boy, out of mere wilfulness, or to get the eggs, there would have been more reason in your anger. Puss made her supper off a wren, which, perhaps, had just swept away a cobweb and dined on the spider, shortly after he had made a comfortable breakfast on a fly. Any 
one would be hard-hearted who took pleasure in watching animals thus destroying one anotber; but we must not forget that it is more natural for a cat to catch birds than to purr by the fire-side and lap milk, and that she is no more conscious of inflicting pain when she pounces on a bird, than a chaffinch is when he picks up a grain of wheat."

"But, papa, I am afraid that our cat will have some of the birds that are building in the garden; for yesterday morning, as I was sitting under the walnut-tree learning my lesson, all at once I heard the loud cry of a blackbird, in the place where we found the nest afterwards. He did not fly away though, as he did when we frightened him, but flew about from bush to bush, as if he were very angry, and in a minute all the birds in the neighbourhood seemed to come and join in the screaming. I think there must have been a dozen at least. They did not mind me a bit, for some of them came close to me. 
Just afterwards I saw the cat skulking along through the shrubbery, and as soon as she was gone, the noise stopped. Don't you think they must have been afraid of her?"

"No doubt their instinct told them that the cat was their enemy; but what good they thought would come of their screaming, I cannot say. Perhaps, when birds join together in that way, the cat may fancy that some mischief will happen to her if she persists, and so she is really frightened away. When a hawk comes near a village in summer, you may often see a flock of swallows flying after it, and twittering with their utmost might. I do not suppose that with their soft beaks they could do the hawk much harm; but the robber, bold as he is, always skulks away as if he was afraid to join battle with them. What rejoicing there must be among the swallows when their enemy is gone !"

"But how comes it that the small birds never take any notice of my hawk? I have often 
seen chaffinches and tits come and perch in the same tree with him, and hop about from branch to branch as if he were one of themselves."

"I have observed the same thing," said Mr. Miller, " and do not know how to account for it. Your hawk is a kestril, not nearly so cunning a bird as the sparrow-hawk, which is the one hustled by the swallows. Perhaps the little birds only know their enemy when he is flying; but your bird cannot fly at all, because one of his wings is cut; or perhaps they do not see him, and he, knowing that he cannot fly, does not attempt to chase them. Some ornithologists say that the kestril lives on mice and beetles, and never kills birds; but others say they have seen them pounce on birds. $I$ must confess that I am inclined to agree with the last, for your hawk picks off the feathers of the small birds we give him, quite as if he was following a natural habit."

"But we have talked enough about birds for the present, so now for lessons." 


\section{CHAPTER VI.}

EGGS WHITE, SPOTTED WITH RED, BROWN, OR BLACK.

House Sparrow.-Pyrgita domestica. Plate II. Fig. 2.

I'His familiar, nay saucy little bird, would seem to have lived so long in the society of man, as to have learnt to imitate him in the variety of his dwellings. No place comes amiss to it. Does a chimney smoke when we light our first autumnal fire?-ten to one that a pair of these birds has not stuffed it up with a bundle of hay and feathers. Is a leaden spout found to be choked?a house-sparrow, in all probability, is the culprit. Does a wooden shoot unexpectedly overflow during a thunderstorm?-no one is to blame but those troublesome sparrows. A pigeon-house is left unoccupied; but before a season has passed, a troop of house-sparrows 
I.
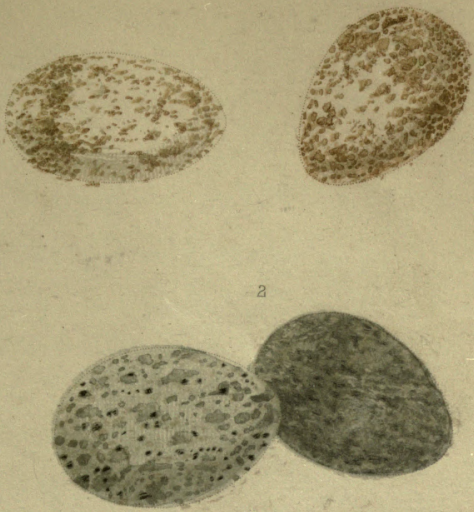

3
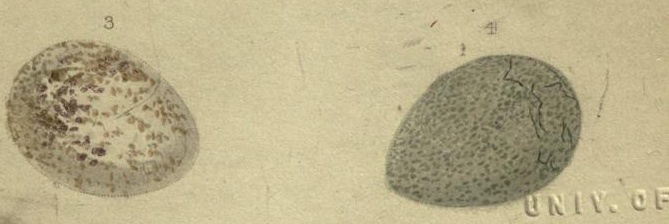

have taken possession. Is a hole left in a wall to let air into a loft or garret?-it is forthwith rendered useless by a sparrow's nest. Do the eaves of a thatched cottage show symptoms of decay? - a flock of sparrows discover the weak point, and add to the mischief by excavating dwellings for themselves. A hole in a tree offers an asylum to another pair; to auother the branches of a poplar, or a mass of knotted ivy; while by others, as dishonest as idle, the newly finished and carefully plastered dwelling of a house martin is most unscrupulously appropriated. The materials of which the nests are constructed, are scarcely less varied than the site. Unsophisticated sparrows, if such there be, probably confine themselves to hay and feathers, but one would not be unlikely to find in any casual nest the following heterogeneous articles, - a bit of red cloth, a lock of wool, a few scraps of paper, a piece of stay-lace, a tuft of hair, a shoe-tie, \&c., all interwoven with hay and feathers. But though 
the sparrow is impudent to men, and overbearing to other birds, its character is redeemed by its extreme attachment to its young, as may be proved by the following well-authenticated anecdote:-

"A pair of sparrows who had built in the thatched roof of a house at Poole, were observed to continue their regular visits to the nest long after the time when the young birds take flight. This unusual circumstance continued throughout the year; and in the winter, a gentleman, who had all along observed them, determined on investigating its cause. $\mathrm{He}$ therefore mounted a ladder, and found one of the young ones detained a prisoner by means of a piece of string or worsted which formed part of the nest having become accidentally twisted round its leg. Being thus prevented from procuring its own sustenance, it had been fed by the continued exertions of the parents." The eggs, which measure somewhat less than an inch, are white, spotted, and streaked with 
ash-colour and dusky brown, the number and size of their spots being liable to considerable variation.

\section{Tree Sparrow.-Pyrgita montana.}

The nest of this bird closely resembles that of the preceding; the eggs too are very similar, but smaller. They may, however, be easily distinguished by observing whether the plumage of the female resembles that of the male. Both sexes of the Tree Sparrow have the feathers of the head of a bright chestnut colour, and a white ring round the neck; while the female House Sparrow has the head and neck of a uniform brown colour.

\section{Pied Wagtail.-Motacilla Yarrellii.}

\section{Plate II. Fig. 4.}

As the Wagtail spends so large a portion of its time in the vicinity of water, now searching for aquatic insects in the mud, now skimming the surface of the pond or stream, and cap- 

94
BIRDS' NES'IS.

turing its prey, and anon coursing over the aquatic weeds with so light a step, that not even the slender water crowfoot bends beneath its weight, - we should expect that, for the convenience of supplying its young with food, it would place its nest not very far off. And such is the case. A hole in a hedge, the side of a crumbling bank, a convenient corner in a dilapidated bridge, the gnarled root of a tree, any of these places is likely to contain the snug little nest of the wagtail. It is built of dry grass, roots, and moss, and lined with finer roots and hair, and usually so placed as to be arched over by the substance in which it is built. The eggs are from four to five, three quarters of an inch long, of a dull white ground, with numerous blackish spots interspersed with lines or blotches of the same colour, and occasionally approach in colour and markings those of the sparrow. The nest and eggs of the Yellow Wagtail $(M$. flava) closely resemble those of the Pied 


\section{BIRDS' NES'TS.}

Wagtail, so that it is not safe to decide on the species to which any particular nest belongs, unless the old bird has been observed to quit it.

Chimney Swallow.-Hirundo rustica. Plate II. Fig. 1.

So great is my respect for this the most welcome of all our summer visitants, that I have never voluntarily intruded on its privacy. The only nest, indeed, which I have seen, is that figured in the cut. One of the laths supporting the roof of an outhouse, intended for a calf-pen, had been accidentally broken, so as to be suspended by only one extremity. To this a pair of swallows had, with great masonic skill, attached the birth-place of their future brood. Seemingly well assured that both the lath was strong enough to support their dwelling, and that the disaster which had befallen one end of it, would not happen to the other, they laid a solid foundation of mud, bits of straw, and roots, working the 
whole into such a shape, that one might suppose them jealous of their Chinese brethren. "If the latter," one may imagine them to have thought, "construct nests which are

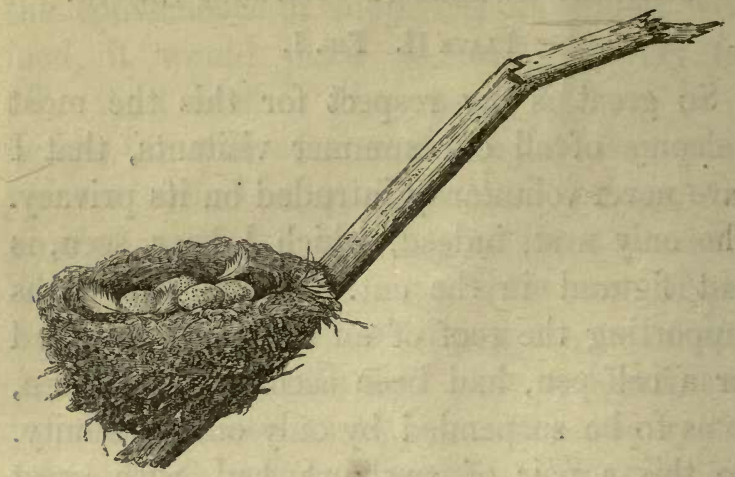

SWALLOW'S NEST.

convertible into soup, we, for our parts, will not be outdone. Behold, then, our attempt at a soup-ladle!"

The plaster is from one to two inches thick, lined with hay, and finished off with feathers. Their ordinary place of building is said to be 
chimneys, unused shafts of mines, or old wells ; sometimes under the roof of a barn or open shed, between the rafters and the thatch or tiles which form the covering. Yarrell speaks of a nest made by a pair of swallows in the half-open drawer of a small deal table in an unoccupied garret, to which access was obtained by a broken pane of glass. Pennant mentions an instance in which a pair of swallows attached their nest to the body and wing of an owl nailed against a barn. A yet more singular instance is recorded of a pair which built their nest in the paddle-wheel of a steamer, and reared their young, although the vessel was daily put in motion. The eggs, which are generally from four to six in number, are three quarters of an inch long, white, speckled with ash-colour and brownish red.

\section{Nuth a тCH.—Sitta Europæea. \\ Plate II. Fig. 3.}

A DESCRIPTIOn of the nest and eggs of this interesting bird will be found at p. 12 . 


\section{Great Tit.-Parus major.}

\section{Plate III. Fig. 2.}

The Greater Titmouse usually lays its eggs in the holes of trees or walls, constructing its nest of moss, hair and feathers. It seems also to have a strong predilection for the deserted nest of some other bird, as the crow, magpie, or nuthatch.* I cannot say to what this caprice in the choice of a home is to be attributed: perhaps to indolence, for he sometimes takes refuge in a hole, and there establishes himself without building any nest whatever; perhaps to love of variety, a trait in his character which is quite consistent with his pert and foppish air. One place of resort is certainly quite his own, that, namely, of an unused pump, of his selecting which there are many instances on record. The Greater Tit lays from six to nine eggs, elosely resembling those of the nuthatch, except that the 

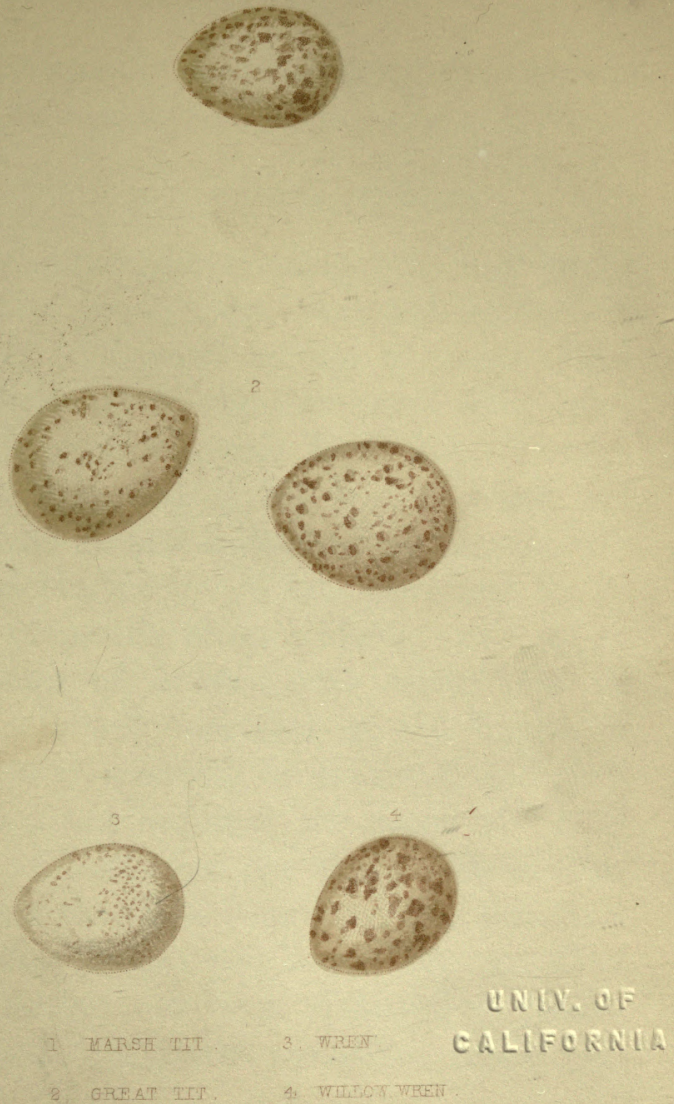
70. Nistis

c. IMgOFISA 
spots are usually smaller, more scattered, and of a lighter colour.

\section{Tом-тіт.-Parus cœruleus.}

T'HIS active and amusing little bird builds its nest of grass, moss, hair, and feathers, in the holes of decayed stumps of trees. Here it lays from six to eighteen small white eggs, copiously speckled with light red. Though diminutive in size, it has a stout heart, and will defend its nest against all aggressors with patriotic obstinacy. When disturbed on its nest, it frequently utters a hissing noise, either in defiance of, or to strike terror into its enemy. It will even peck at the fingers of any one who attempts to molest it, and from this habit has acquired the name of "Billy Biter." So attached are these birds to their nests, that they have been known to rear their young after the stump in which they have fixed their dwelling has been shattered to pieces. The Marsh Tit (Parus palustris), (Plate III. 
Fig. 1), the Cole Tit (Parus ater), the Creeper (Certhia familiaris), all have nests and eggs so closely resembling those of the Blue Tit, that they are scarcley to be discriminated except by watching the parent birds while leaving the nest.

\section{Long-Tailed Tit.-Parus caudatus.}

If in the course of his rambles, the eggcollector should observe an oval mass of soft green moss skilfully intermatted, woven together with cobwebs, decorated with scales of silvery lichen, and covered above and on all sides with the same beautiful material, with the exception of a small hole on the least exposed part, through which he cannot introduce more than two of his fingers without damaging the structure, he may be pretty sure he has discovered a nest of the Longtailed Tit. He will not, of course, disturb it, but if he waits till the brood is fledged, he will do well to cut down the branch in which 
it is built, and suspend it in his 'museum as a specimen of the utmost skill which any British bird can display. Who could believe that from seven to twelve or more living, flying, chirping birds were all reared within this hollow ball? But that they were so he may even yet, if he pleases, satisfy himself by watching the whole brood, with their parents, flying about the hedges in the neighbourhood. One would fancy that, having been so long packed together in their snug little chamber, they could not bear the idea of separating; for, during the whole of the remainder of the season, and, indeed, until pairing time returns, the whole family continue to hunt together in familiar intercourse. One cannot help wondering, too, what the whole of the family did with their long tails while they all remained shut up at home. Nor is the wonder diminished by an examination of the inside of the nest, for the cavity is all but filled with the softest and warmest of feathers. The 
"eggs are, next to those of the golden-crested wren, the smallest found in Britain, white, and sparingly speckled with light red, chiefly near the larger end: and not unfrequently they are of a spotless white.

\section{Wrliow Wren.-Sylvia Trochilus. Plate III. Fig. 4.}

ON its first arrival, this pretty little warbler is most frequently observed flying about the tops of lofty trees, repeating again and again its short but agreeable melody. As the season advances, however, it chooses a humbler station, and may be observed creeping about bushes, banks, and hedges; and no doubt, in the course of its peregrinations, ridding us of an infinity of mischievous insects. For its nest, it selects a position lowlier still; a hole in a bank, under the friendly shelter of a tuft of grass or furze, suits it well; or, especially on the skirts of a wood, it does not disdain a hole or rut on the very ground. Here 
it constructs a nearly globular nest, composed of leaves, bents and moss loosely put together, and thickly lined with feathers. It is entered through a small hole in one side. In the eastern counties, the country people call it a "ground-oven." The bird lays six or seven white eggs speckled with light red. It has been observed that the Willow Wren is strongly attached to its nest, and will not forsake it, though it has been frequently disturbed.

\section{Chimfchafr.-Sylvia Hippolais. \\ Plate IV. Fig. 1.}

'TuIs bird, which is with difficulty distinguished from the willow wren, except by the monotonous note from which it derives its name, constructs also a very similar nest, usually, however, choosing to place it in a bush a short distance from the ground. The egg may be distinguished by its fewer spots, which are of a dark purple colour, approaching black. 
104 BIRDS' NESTS.

Wood Wren.-Sylvia sibilatrix. Plate IV. Fig. 3.

The Wood Wren builds its nest upon the ground, generally in woods, under a tuft of grass; it is like that of the willow wren, but is lined with hair instead of feathers. The eggs, seven in number, are white, thickly speckled with dark purple, red, and ash-colour, almost hiding the ground.

\section{Common Wren.-Troglodites vulgaris.}

\section{Plate III. Fig. 3.}

A Description of the nest of the Wren may be found at page 79. The number of eggs varies from six to eight, or sometimes, it is said, even more. They are pure white, and scantily speckled with dark red, the spots being, for the most part, confined to the larger end. Occasionally they are spotless. 
BIRDS' NESTS.

Lesser Whitethroat. - Curruca Sylviella.

$$
\text { Plate IV. Fig. } 2 .
$$

THe nest of this bird is chiefly remarkable from the looseness with which its materials are put together (see page 111). The eggs, four or five in number, are nearly white, long in proportion to their breadth, and copiously speckled, especially towards their larger end, with olive grey and dark brown.

Greenfinch.-Coccothraustes Chloris.

$$
\text { Plate IV. Fig. } 4 .
$$

The Greenfinch, or Green Linnet, as it is sometimes called, is most commonly observed in winter congregating with spárrows and yellow buntings. In the breeding season, however, it alters its habits, and becomes quite solitary. It builds its nest in hedgerows rarely less than ten or twelve feet from the ground. It frequently resorts to gardens and 


\section{BIRDS' NESTS.}

shrubberies, and places its nest high up in a laurel, yew, cypress, or apple tree. While incubation is going on, the male bird is in the habit of perching in some neighbouring high tree, where, for an hour or two together, he repeats, at regular intervals, a monotonous long-drawn chirrup, scarcely more musical than the croak of a frog; at other times, while moving from branch to branch, he utters a short inquiring note, resembling in tone some of the softer notes of the Canary bird. The nest is composed of moss and wool interwoven, laid on a foundation of small sticks, and lined with fine roots, horse-hair, and feathers. The eggs, five in number, are bluish white, spotted at the larger end with purplish grey and dark brown. 


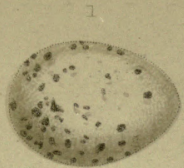

$-2$

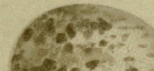

if. $24=5$

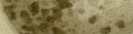

with 20
,

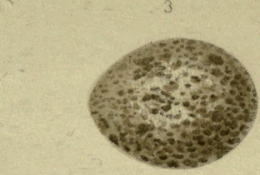





\section{CHAPTER VII.}

A FEW days after this conversation, Mr. Miller proposed a walk to a village about two miles off, and, as he expected, found in his son a willing companion. Their road lay partly through some narrow lanes, then across a common, and finally through some fields ; and as birds had been lately so frequently the subject of conversation, they were watched with more than usual interest. They saw, however, nothing but what every one may see during a similar walk, here and there a thrush perched near the top of a tall tree, pouring forth his rich and varied song, and keeping his post till the strangers stopped beneath him, when he noiselessly darted off to another tree in an ad- 
joining hedge to finish his melody; so different from the blackbird, which always takes flight with a harsh cry, sounding more like impudence than fear;-larks everywhere, high in air, and never seeming to be high enough, waving their wings without ceasing, and all the while chanting their happy ti-ra-li-ra. Wonderful indeed is their strength of lungs! If a man runs for ten minutes, he pants so violently that he can scarcely speak; but a lark seems to put his whole strength into his wings, and carols away all the while as composedly as if breathing and singing were equally easyperhaps we should say, as if singing gave him strength instead of exhausting it. A pair of bullfinches were observed to fly along the lane, one a few yards behind the other, easily distinguished by their dipping flight, and by a spot of pure white just above the tail. Then they stopped to watch a chaffinch which was hopping from twig to twig, looking anxiously round, and uttering a pathetic note, very dif- 
ferent both from the ordinary call-note, and from the cheerful spring song.

"That bird," said Mr. Miller, "has its nest very near us. The chaffinch only uses that note when some stranger comes near its nest. I have many times found one by looking carefully in the trees about which it flies, while making that anxious noise. Their nest is very beautiful, built usually among crossing branches, or in the fork of a bough, but so securely fixed that it can rarely be removed entire without cutting off one or more branches. It is of moss lined with hair and feathers, and decked with moss and bits of white lichen, in such a way as to be quite smooth even on the outside. The rim, too, is different from that of most other birds' nests, neither left rough nor made flat, but as beautifully rounded as if it were turned in a lathe. When the chaffinches which have built in our laurel at home have reared their young, we will cut off the branch in which is their 


\section{BIRDS' NESTS.}

nest, and you may have it for your museum. But see, there is a pair of lesser whitethroats; they are certainly here on business. Watch where they fly, and we shall have a chance of seeing a very different kind of nest."

Both father and son stopped and watched very carefully for several minutes. The birds, however, did not seem disposed to give them the desired information. They flew first to some tall elms a short way off, then returned to the hedge, bustled in on one side and out again at the other, then crossed the road, and flew up and down the lane, but without once showing that they preferred one spot to another.

"Well, then," said Mr. Miller, "since you will not show me the way to your house, I must find it by myself. Do you search carefully down this side of the lane, and I will take the other. You need not look on the ground, nor in the high trees, but only in the thorns and brambles, a few feet above the ground." 
Henry had not walked many yards, when he cried out in great delight- "Here it is; I have found it! - no, it is only a bit of hayyes, I have! but it is not half finished."

"Don't be too certain of that; let me see."

"Oh, I am sure that it is not finished, for I can see through it."

"What is this then?" said Mr. Miller, as he carefully withdrew his hand from the nest, holding a small white egg, beautifully spotted with greenish-brown. "Do birds lay their eggs before they have finished their nests? However, I am not surprised at your thinking it unfinished, for, as you see, the nest is built of fine stalks, crossing each other at such distances as to have the appearance of coarse network. But the skill of this bird seems to me to be quite as wonderful as that of the chaffinch-first, that it should be able to make the inside round with such materials as these; and secondly, that it should be able to put them 
together so compactly as to be equal to bearing the weight of four or five young birds, and that the structure should all the while be so flimsy in appearance that one can see through it. I have only once before seen one of these nests, and that was when first I came to live in this county. I several times saw a bird which I supposed to be a greater whitethroat fly from the same bush, and after searching more than once, I found what I supposed to be an unfinished nest. At length, being surprised at the time which the birds took to build their nest, I put my fingers in, and to my great astonishment found three eggs."

"And how did you know that it was a lesser whitethroat's nest?"

"Why, oddly enough, Mr. Dean called on me the same day, and asked me to tell him the name of a little bird which he had just shot. I had never seen it before, but on consulting Yarrell's British Birds, I found it was a lesser whitethroat, and on inquiring of $\mathrm{Mr}$. 
Dean where he had killed it, he mentioned the very bush where I had found the curious nest. I turned to Yarrell again, and saw that his description of that bird's nest agreed exactly with the one which I had found."

"And the other bird deserted, of course?" "No, indeed! Mrs. Whitethroat was not very faithful to the memory of her dead and stuffed husband. A few days afterwards I happened to be passing by, and saw the old bird sitting on her nest. She flew away, as I disturbed her, and I found five eggs in the nest instead of three, and I presently saw a pair of the same birds fluttering about as we saw them just now. I concluded, therefore, that the lady, affronted that her husband had deserted her, had chosen another mate to sing to her while she was staying at home, and to help her in rearing her brood."

"But, perhaps, the bird that Mr. Dean shot was not her husband at all."

"Why, of course, I cannot say for certain 
114. BIRDS' NESTS.

that he was, but as pairing time was long past, it was not at all likely that another Mr. Whitethroat was visiting his friend. Birds are very jealous of any stranger of their own kind coming near their nest, and I particularly asked Mr. Dean afterwards, if the bird was fighting when he killed it. He was quite sure that the one he shot was one of a pair, as he watched them for some time bustling about together in a very friendly way. The attachment of birds for their nests must be very strong indeed, if neither the report of the gun nor the absence of the husband drive the female from her eggs."

"Did she know that her husband was killed?" asked Henry.

"I should think not. We must not suppose that birds have reason enough to know what the effect of a gun is. She was terrified at the noise, no doubt, but I cannot believe that she thought the report had anything to do with her husband's loss." 
"But do not rooks always fly away when they see a man with a gun?"

"Yes, and so they do from a man who holds up a stick; and they will fly away from a man on foot, but take no notice of a man in a cart. The reason of this, I suppose, is, not that they can smell gunpowder, as some people say, but that almost the first time they quitted their nests, and before they could fly away, several men came with guns beneath the trees on which they were perched, and fired at them. I do not suppose that they understood the meaning of their companions' deaths, but, doubtless, they were all terrified to such a degree that they never see a man carrying a gun or stick without fearing that the same thing will happen again. The reason why they take no notice of persons riding or driving is, I suppose, because they have found out by experience that no one on horseback or in a carriage takes notice of them. It is just the same with many other animals, which, though 
very shy when any one on foot comes near, allow a cart or a man on horseback to come quite close to them. I was driving in a gig one day last autumn, and came so close to a squirrel hunting for nuts in a hedge, that I could have touched him with my whip; but had I been a gamekeeper with a gun, he would have been by no means so quiet."

"Why do gamekeepers kill squirrels?" asked Henry.

"Because they do much mischief by eating the bark of larches and nibbling off the shoots of spruce-firs. You may often see the ground strewed with small branches which they have gnawed off. They are said, too, to destroy the eggs and young of pheasants. I don't know whether this is a true charge, but it probably is, as I believe there is no doubt that they eat animal as well as vegetable substances."

"Where do squirrels miake their nests?" "In high trees, and they are so like birds' nests that there is no knowing one from the 
other without climbing up to them. In my younger days, I once climbed a tall tree after what I thought was a hawk's or crow's nest. Just as I was on the point of putting my hand in, out bounced, not an old bird, but an old squirrel, who, whatever his age was, was nimble enough, and startled me so much that I nearly let go my hold."

"And what was there in the nest?"

"Nothing; the pretty little fellow was finishing off the inside of his nest, in doing which he had been so busily occupied that he did not hear me until I was close upon him. It was well for me that he heard me then, for if I had put my hand into the nest while he was there, he would, I dare say, have bitten me very severely."

"Should you have caught him if you could, or have taken the young ones if there were any in it?"

"Certainly not! I have no fault to find with keepers for killing the animals which injure their masters' woods and destroy their 
game; but that is no reason why I should do their work."

"But don't you think a squirrel a very pretty animal, in a cage? I saw one once in a wire whirl-a-gig, which he made spin round very fast; and there was a little room with a door leading into it, in which he slept; he seemed very merry and comfortable."

"I can't deny," said Mr. Miller, "that a squirrel is very pretty everywhere; but I cannot believe that there is much merriment in spinning round a wire cage, or that he finds any pleasure in his dark box, or 'room,' as you call it, except the comfort of finding a place where he can be still, if he likes. Did you ever hear of a treadmill?"

"No, never," said Henry.

"A treadmill is a very large wheel, in shape something like a squirrel's cage, with the exception, that where the wires are, there are wooden steps. This wheel is connected with a mill for grinding corn, and is turned by a row of men, who hold fast by a wooden rail, 
and stand on the steps outside. The wheel is set in motion by their weight, and as one step sinks under their feet, they are obliged to take another, or they will have their shins bruised. The labour is so severe that only strong men can stand it; and it is imposed as a punishment on thieves, and other criminals, who have been sent to prison. Now, a squirrel's cage is a treadmill, except that the poor animal works alone, instead of in company: and, for my part, I see no reason why he should be shut up in a prison and treated as a rogue all his days for the amusement of cruel people, who, I dare say, deserve such treatment much more than he does."

While this conversation was going on, the father and son had reached a part of the road where a labourer was cutting down a hedge. They stopped to speak to him, and the man, observing thatHenry carried an egg in his hand, the one which they had taken just before from the lesser whitethroat's nest, said- 


\section{$120 \quad$ BIRDS' NESTS.}

"I found a nest in a thorn-bush which I cut down this morning, and have laid it on the ground a few yards back; you are very welcome to it, if you would like to have it. There are four or five eggs in it, but I don't know of what sort they are."

"I hope," said Mr. Miller, "that you do not wantonly destroy the nests that come in your way."

"No, Sir; birds' eggs are of no use to me, and there is plenty of room in the world for me and them; but when my orders are to cut down a hedge, I cannot leave every bush standing that happens to have a nest in it."

With these words, he fetched the nest, and placed it in Henry's hands. It was a large nest, made of dry goose-grass and moss, with a lining of hair, and contained five eggs, of a delicate cream-colour, mottled with buff.

"Oh," said Mr. Miller, "this is the nest of a butcher-bird, or red-backed shrike."

"A butcher-bird!" exclaimed Henry; 
" what an odd name for a bird! I suppose it kills other birds."

"Indeed it does not bear a very good name. Naturalists say that it frequently catches a bird smaller than itself, and after killing it by repeated blows of its bill on the head, fixes it on a thorn, or jams it into the fork of a tree, and devours it bit by bit. He may often be seen perched on the end of a twig, watching anxiously for his prey, which is usually a cockchafer, or some other kind of beetle. Suddenly he darts off, hovers in the air like a hawk, and having seized some unhappy insect, bears it away to the nearest hawthorn bush, fixes it on a thorn, and devours all but the hard wing-cases. The little birds seem to be aware of his murderous habits, for they sometimes hunt him, and scold at him, as they do a hawk, or an owl when he ventures out by day."

Another nest was obtained soon afterwards, that of a missel-thrush. It had been built in the fork of a crab-tree, not very far from the 
ground; and it seemed as if some mischievous boy had discovered it, and not being able to reach it, had upset it with a stick. The remains of several eggs lay on the ground, but one was still left in the nest. It was of a dull green colour, spotted all over with red. The nest was built of hay and stems of goosegrass; then came a layer of moss and mud matted together, and the lining was of soft dry grass.

The eggs found that morning now amounted to seven, and Mr. Miller, afraid that they might get broken in the carriage, seated himself on the trunk of an oak which had been recently felled and stripped of its bark, and blew them. This done, the eggs were placed in the larger of the nests, and covered by the other, and were then hidden among some thick herbage, to be taken away as they returned. 


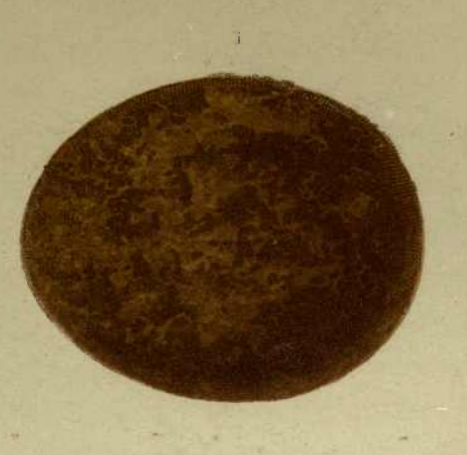





\section{CHAPTER VIII.}

EGGS SPOTTED, ON A LIGHT GROUND.

\section{Sparrow Hawk.-Accipiter Nisus.}

\section{Plate V. Fig. 2.}

The Sparrow Hawk, like many other birds of the same tribe, is more of a robber than a builder, establishing itself in the deserted nest of some other bird, especially the crow. It lays four or five eggs an inch and a half long, of a pale bluish white, blotched and speckled with dark red brown. The young when hatched are very voracious. Mr. Selby mentions having found a nest of five young sparrow hawks, which contained a lapwing, two blackbirds, a thrush, and two greenfinches, recently killed and partly stripped of their feathers. If taken young, and abundantly supplied with proper food, they may be reared without difficulty and trained for hawking. 


\section{Kestril.-Falco Tinnunculus."}

\section{Plate V. Fig. 1.}

In mountainous districts, the Kestril usually places its nest on cliffs or on craggy banks, scraping a slight cavity for its eggs. On the coast, it resorts to rocks; or in the interior, to ruined castles or other buildings, and sometimes to towers or steeples. In flat, woody districts, it often takes possession of the deserted nest of a crow or magpie; but appears to prefer rocks whenever they are to be met with. The eggs, which vary from three to five, and are nearly as broad as they are long, are of a pale reddish white colour, confusedly dotted or blotched all over with dull brownish red, and often so closely that the ground colour of the egg is entirely concealed. Young Kestrils taken from the nest may easily be reared, and, if duly fed, will habitually return to the place where they have been brought up, for a long time after they have acquired the power of escaping.*

* See the Author's "Pet Animals."-(S.P.C. K.) 
BIRDs' NESTS.

\section{JACKDAW.-Corvus Monedula.}

\section{Plate VIII. Fig. 3.}

The Jackdaw, like most large birds, the nests of which from their size are conspicuous objects, usually fixes his abode in elevated places, frequenting and building in churchtowers, belfries, steeples, quarries, and the face of perpendicular cliffs, and not unfrequently selecting a hollow tree. The nest, which is often of very large size, is constructed of dry sticks, and is lined with wool or other soft substances. In the Botanic Garden at Cambridge, a city which, from its numerous spires, affords these birds abundance of convenient lodging, they have been found a perfect nuisance, by purloining the wooden labels used for marking plants - no less than eighteen dozen have been taken from one nest. In the frontispiece of Mr. Jesse's "Scenes and Tales of Country Life," is a representation of a nest built in the bell-tower of Eton chapel in seventeen days-May, 1842. It measured ten feet 
in height, and formed a solid stack-work of sticks. The eggs of this bird are bluish white, spotted with ash colour and dark brown. The young birds are easily tamed, and soon become amusing but mischievous pets.

\section{Moor-Hex.-Gallinula chloropus.}

\section{Plate VI. Fig. 2.}

AMONG the notes of the feathered tribe there are many which have no claim to be considered melodious, and among these is the cry of the Moor-hen; but though not musical, it falls pleasantly on the ear, as one is walking, in summer, on the bank of some winding river; and the eye cannot fail to follow with interest the dingy bird itself, with its yellow stockings and scarlet beak, as it shuffles, half-flying, half-swimming, from a tuft of weeds or willows to a distant place of security, seeking safety either by paddling between the reeds which line the opposite bank, or when it has reached deep water suddenly bobbing down to 

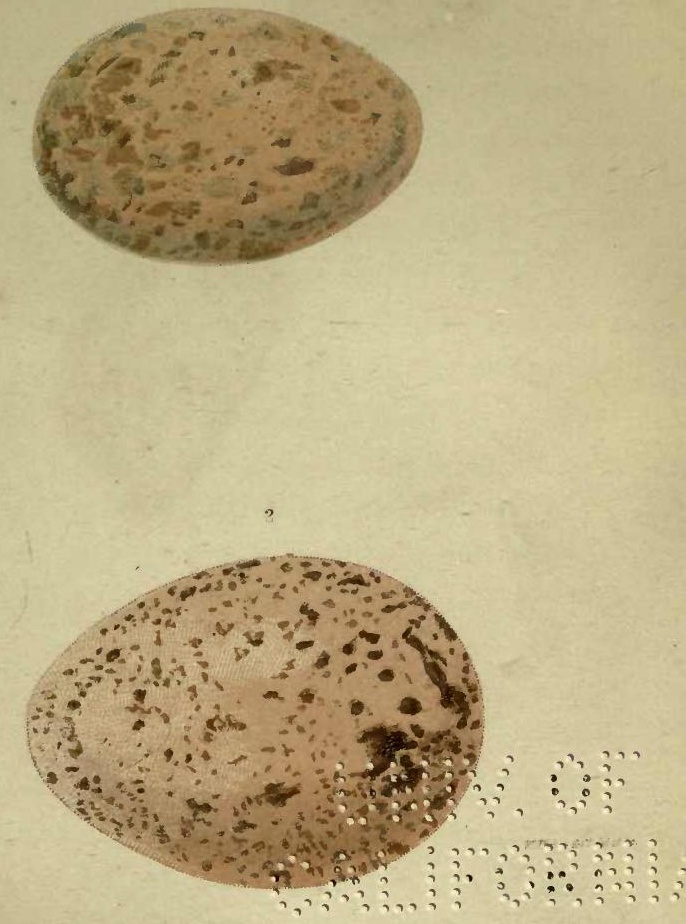

1. HALITRATI 2. MOTHEN . 

reappear for a few seconds, no one knows how many yards up or down the stream. In the watery thicket which has just been deserted with such precipitation may be found, if only one has courage to risk a wetting, a compact nest of reeds, sedge, and other coarse waterplants, containing seven or eight reddish-white eggs, blotched and speckled with chocolate colour. The nest is often placed so near to the water as to be carried away by the summer floods; but an instance is recorded in which the parent birds, warned by instinct or experience of the impending danger, added to the structure of the nest until their eggs were out of reach of the rising water.

\section{LaNdRAIL.-Crex pratensis. \\ Plate VI. Fig. 1.}

The Landrail or Corncrake, far more often heard than seen, makes a very slight nest of dry grass, generally in hay-fields. Its eggs are from seven to ten; they are of a pale 
reddish white, spotted and sprinkled with ash grey and brownish red.

\section{Quall.-Perdix Coturnix. \\ Plate XXII. FIg. 2.}

This bird, like the last, builds a very slight nest of dry grass in meadows and corn-fields. The eggs are about ten, cream-coloured and variously mottled, blotched or spotted with reddish-brown.

Missel-Thrush.-Turdus viscivorus.

Plate VIII. Fig. 4.

DuRING the greater portion of the year the Missel-thrush is noted for its shyness. Its harsh note, indeed, resembling the sound caused by drawing one's finger along the teeth of a comb, may frequently be heard from September to February, and as one draws near the grove from which the sound proceeded, the bird itself may often be observed making off rapidly, and in a straight line, for some other shelter; but unless the weather be very 
severe, or the bird be so deeply engaged in an angry squabble with some winged intruders on his repast-for to tell the truth, he is neither good-tempered nor sociable-he allows no one to approach him. As the breeding season, however, draws near, he alters his very nature. No longer confining himself to the woods and wilds, he draws near our dwellings, pitches his tent in an orchard or shrubbery, and there, very early in the season, builds in the fork of an apple or some other such tree, a substantial nest of hay, stems, lichens, and mud, lined with dry grass. $\mathrm{He}$ seems indeed now to court observation as much as he formerly shunned it; for no nest perhaps is more open to detection. The eggs, usually five, are of a light brown, reddish or greenish hue, blotched or speckled with light red.

\section{Butcher Bird.-Lanius Collurio. Piate VII. Fig. 3.}

IN some districts, nests of this bird are tolerably common, but in other parts, especi- 
ally in the north of England, they are of rare occurrence. The nest is usually placed in a thick hedge or bush, and is composed of bents and slender stems, and lined with grass and a little hair. The eggs are remarkable for the variety and delicacy of their tinting. Three nests, found all in the same season, contained each five eggs. Those of one set were creamcoloured, irregularly blotched with grey and light brown; those of another were of a pinkish hue, speckled with light red and purplishbrown; and those of the third were bluishwhite, having near the larger end a ring of ash-coloured spots. It is hard to say which of the three is the most beautiful.

\section{GoLdFInch.-Carduelis elegans. Plate VIII. Fig. 2.}

THe neat habitation of the Goldfinch is worthy of its brilliant and sprightly owner. It is small, and composed of moss and roots felted together with wool; externally decorated 

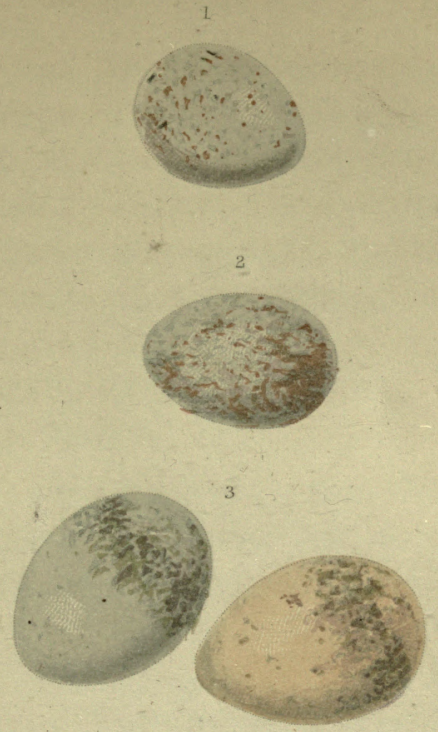

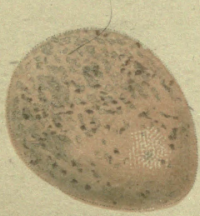

I. INNNET.
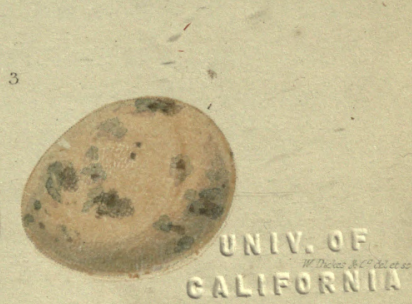

2. FHYCATCHER . 
with lichens, and lined on the inside with thistledown, the cotton of the willow, and the softest of feathers. It is usually placed among the twigs of an apple-tree, pear-tree, or evergreen, and contains five eggs of a bluish-white tint, speckled with pale purple and brown.

\section{LINNET.-Linaria cannabina. Plate VII. Fig. I.}

WEARING a more sober livery than the goldfinch, the Linnet also makes less display of architectural neatness ; and instead of choosing a place of resort where it is likely to be exposed to the common gaze, it retires in the breeding season to some thicket or furze-brake, where, especially in the latter situation, it constructs a nest of small twigs, moss, roots, and wool, lined with hair, feathers, and sometimes thistle or willow-down. The eggs are four or five, and closely resemble those of the goldfinch, both in size and colouring.

$$
\text { к } 2
$$


132. BIRDS' NESTS.

\section{RoBin.-Erythaca Rubecula. Plate VIII. Fig. 1.}

Most books on British birds contain accounts of singular places chosen by this familiar little bird wherein to build its nest. The following instance may be added to the list:- In the author's garden is a thatched shed, daily resorted to by many persons for the purpose of sifting earth, mixing soil, potting plants, \&c. Immediately over the place where these operations were carried on, there stood, in the spring of 1853, an empty beehive. A pair of robins discovered and approved this site for their habitation, and so little were they disturbed by the intrusion of visitors, that they actually reared their brood before the nest was found. Most frequently, the nest is placed in a long hole of a bank or hedge, sheltered by moss or weeds, and not unfrequently in an ivy-covered wall, such as that described in Mrs. Trimmer's inimitable tale. The eggs, about five in number, are dull white, spotted with light red. 
Spotted Flycatcher.-Muscicapa grisola. Plate VII. Frg. 2.

In the spring of 1853 a pair of these birds built their nest in the fork of an apricot-tree, which was trained against a barn in my garden. Five eggs were laid, and in due season hatched. 'The parent birds were often observed supplying the young ones with food; and at last, when they disappeared I supposed that their labours were ended. One day, however, as I was at work in another part of the garden, a pair of flycatchers flew about uneasily near the place where I was standing, now perching on the branches of a pear-tree, then on the top of a wall, and evincing that anxiety by which birds frequently betray the vicinity of their nest. I searched every tree and niche where $I$ thought it possible that a flycatcher could build its nest, but all in vain. The next day, and the next, the same incident occurred, and so thoroughly was I convinced that there must be a nest somewhere near me, 


\section{BIRDS' NES'T'S.}

that I twice repeated my search. On the fourth day, happening to look at some plants growing on a hotbed hard by, I discovered a young flycatcher, which was evidently the cause of all the anxiety that I had witnessed. It was quite fledged; but owing either to some accident or natural malformation, was unable to fly. It had only one eye, and the beak was twisted on one side, with the upper and lower mandible crossing each other. My first impulse was to kill it, as I thought it impossible that it would ever be able to feed itself. The continued anxiety of the parent birds, however, who still hovered about me, deterred me from taking this step, at least in their presence, so I left it to its fate. About this time a young kestril, which was being brought up in the house, was allowed to go at large in a meadow adjoining the garden. The day after my discovery of the poor young flycatcher, I observed the kestril scrambling across the meadow, and making for a cherrytree some twenty yards off. As it approached 

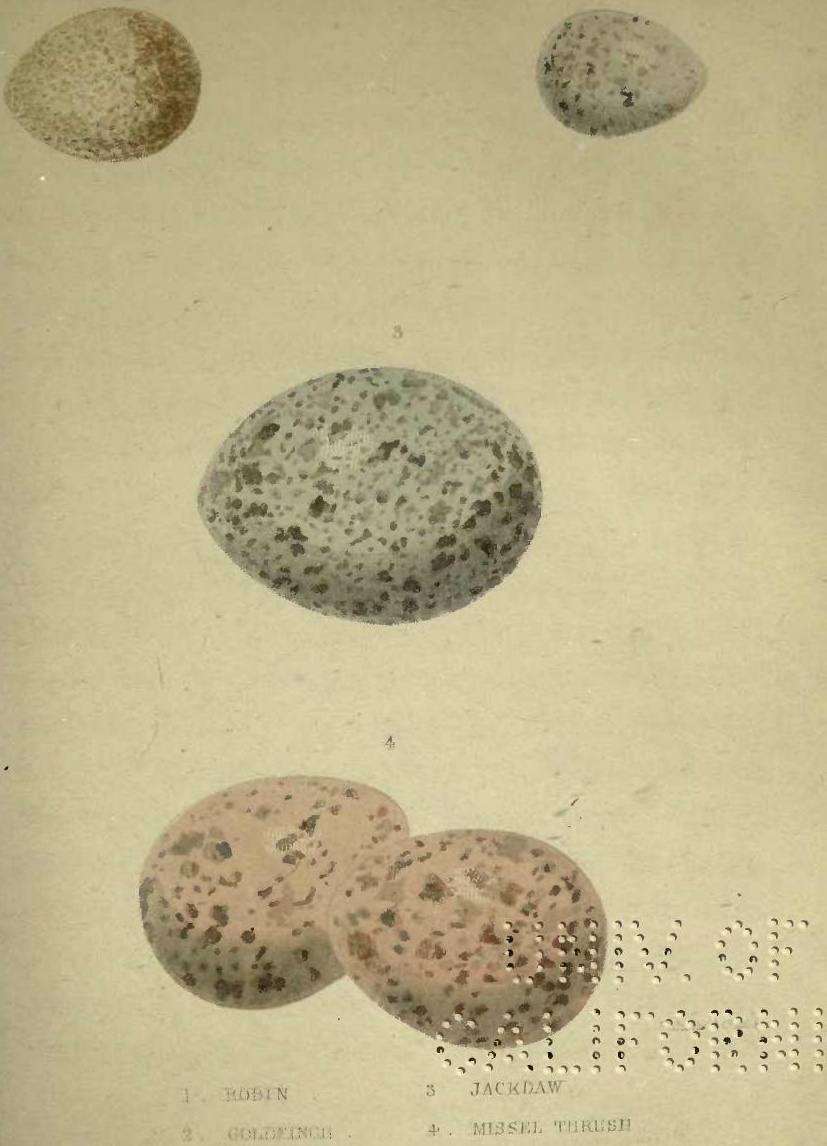

the tree, a pair of flycatchers, whom I had not noticed before, suddenly darted one after the other from the branches of the tree, pecking at the head of the hawk as they flew by. The young bird of prey not being himself quite fledged, was not able to resent this insult, but every time that they approached him dipped his head in fear; until, at last, tired of a game, all the sport of which was on the other side, and getting a peck hard and sharp enough to have been dealt in good earnest, he hobbled away discomfited to the garden. I have no doubt that what gave these birds courage to attack an enemy so terrible as a hawk, was a feeling of affection for their helpless offspring, which, since my discovery of its retreat, had been conducted by them to another place of concealment.

The nest of this flycatcher is usually built in fruit-trees trained against walls, or projections from buildings, or on the stout branch of a tree; and it seems to prefer gardens to the 
open country, because probably flies are there more abundant. The nest is made of moss, bents, and roots, lined with dry grass, hair, and feathers. The eggs are very similar to those of the robin; but the ground has more of a bluish or greenish tinge, and the spots are larger and of a more decided red.

REED W ARBLER. - Salicaria arundinacea. Plate IX. Fig. 2.

I HAVE never seen the nest of this bird: but to judge from the description and figure of one given by Yarrell, it must be a very interesting object. "It was supported between four reed-stems, and was taken from a bed of reeds on the side of the Thames, the surface soil of which was covered by water every tide, or twice in every twenty-four hours. The nest is formed of the seed branches of the reeds, and very long grass wound horizontally round and round, including the four upright reeds in the substance-thus forming with a little wool the 
sides of the nest which frequently measures five inches in depth on the outside, three inches in breadth across the top, and three inches deep inside ; the lining is formed of a very fine grass and long hairs. The nest is made so deep that the eggs do not roll out when the supporting reeds are waved by the wind, and the bird has been seen sitting on her nest when every gust forced it almost to the surface of the water." The eggs, three quarters of an inch long, are of a greenish white colour, spotted and speckled with ash green and light brown.

\section{Cuckoo.-Cuculus canorus. Puate IX. Fig. 3.}

ENough has been written on the natural history of the Cuckoo, more especially with reference to the laying of its eggs and the rearing of its young, (even if I were to omit the fabulous,) to fill this little book three or four times over. I would recommend the young collector to read a very interesting chapter 
on this subject, in the third volume of "Macgillivray's British Birds." The Cuckoo is thought to lay not less than twelve eggs in the course of a single season. It builds no nest of its own, but selects that of the meadow-pipit or wagtail, and less frequently that of the hedgesparrow, skylark, nightingale, or gardenwarbler. An African species of cuckoo has been shot in the act of carrying one of its own eggs in its bill, and it has been conjectured that its English namesake employs the same instrument in depositing its eggs, at least in some cases, inasmuch as the egg of this bird has been found in a wagtail's nest, the entrance to which was so narrow that it could scarcely have been introduced in any other way. However this may be, there is no doubt that, within a few days after the young cuckoo is hatched, he unceremoniously hoists his fosterbrothers and sisters on his back and tumbles them out of the nest. He seems, too, to exercise a sort of fascination over his foster-parents, 
who, attentive as they are under ordinary circumstances to the wants of their own brood, take no further notice of those who have been turned out of doors by the selfish intruder, but suffer them to perish of want. Indeed the appetite of the young cuckoo is so voracious, that it would be next to impossible for any single pair of birds to supply any more than his need and their own. This extraordinary voracity appears to be owing, in some measure, to the disproportionate size of the egg and adult bird, which makes it necessary that the nestling should grow very fast in order to obtain maturity in time to migrate in September, the period at which the young bird disappears.

How wonderful must be the instinct implanted in a bird which, reared by fosterparents (themselves spending their whole lives in the same country), and never having been taught by example or the society of its fellows, wings its way across the sea, an element of 
140 BIRDS' NESTS.

which it has had no experience, to foreign lands, to which it has no guide, there to join the company of adult birds who have preceded it many weeks! Here, at least, the infidel must acknowledge the teaching of Him who is invisible.

The egg of the cuckoo is of a pale reddish grey, speckled with brown, and exactly the same size as that of the skylark, though the comparative size of the two birds is as four to one.

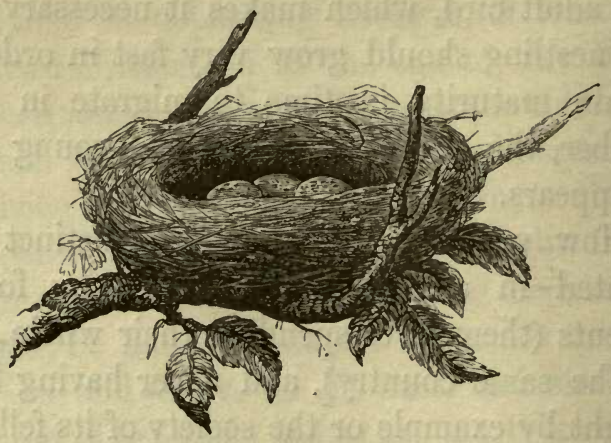

NEST OF BULLFINCH. 

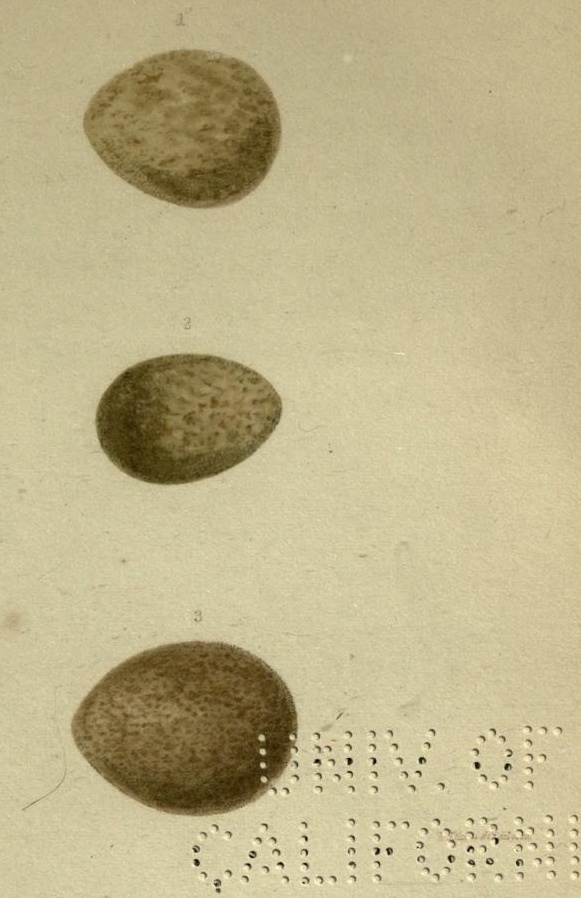

I. GARDPN WARBLER . 2 , REDD WARBTER 

BIRDS' NESTS.

\section{CHAPTER IX.}

IT was now past one o'clock, and as they had yet nearly a mile to walk before they reached the village, Henry was told to walk on steadily, and to think no more of birds' nests for the present; but this was not a very easy order to obey. None but those who have studied some branch of Natural History are aware how difficult it is to a naturalist to walk in the country without noticing the various objects which present themselves. Mr. Miller, however, knew it well; he was acquainted with the names and properties of most of the British plants, and with many of the insects that fed on them; he had made a collection of the land and fresh-water shells which were to be found in his neighbourhood; and long practice had enabled him to distinguish, both by their flight and note, all the 
common birds. In spite, therefore, of his intention to make haste, he found himself frequently stopping to notice something beautiful or unusual. Now, a tuft of peculiarly graceful ferns attracted his attention: now, a damp shady nook covered with exquisitely feathered mosses, of which he wished to discover the fruit; and now, the effort of a wild bee to extract the honey from a flower which had too long a tube for its proboscis to reach the bottom. He had all his life been in the habit of looking out for fresh instances of the "Wisdom of God in creation," and found it difficult to shut his eyes against the little incidents which many people would call trifles, and yet more would not notice at all, but all of which had, to him, a deep meaning.

Henry was following his example. He already knew the names of many of the commonest flowers, butterflies, and birds, and had begun to collect and preserve specimens of the plants which he met with in the course of his 
walks. He was, however, too young to understand the hard words which it is necessary to use in scientific books; and his father thought that if he could foster the taste for natural history, even before he was able to make use of books devoted to the subject, he would hereafter take pleasure in following up the study in good earnest. Mr. Miller had himself never collected birds' eggs, having contented himself with examining the nests, and watching the habits of the birds; but when he saw his son so anxious to possess specimens of the various kinds of eggs, - as he could not with reason say that it was wrong to make a collection of this kind, while it was not wrong to collect birds and insects,- - he did not forbid him; he only insisted that the study should be pursued, as he believed it might be done, in such a way that no cruelty should be practised towards the parent birds. It had been objected to him by a friend that it was an imposition to induce a bird to sit on pebbles, 
which she supposed to be eggs : but he did not admit that there was any force in this objection, because he never allowed more than half of the eggs in a nest to be changed. "You often find," he said, "in a nest, four young birds, and an addle egg. As soon as the young are hatched, the old bird begins to feed them, without being aware of the presence of the fifth egg; nor do I believe, when two out of four eggs are hatched, that the old bird discovers that the other two have been changed into pebbles. I cannot see that there is any cruelty in a deception which she cannot detect, and which saves her a half of the trouble of supplying her brood with food. I allow that it would be unfeeling if any one were to take away all her eggs, and leave pebbles in their place; and, in like manner, it would be unfeeling to allow a hen to sit on a solitary chalk egg; but I cannot conceive that the most scrupulous person would blame a farmer for inducing his poultry to lay in certain places, 
by supplying them with imitation eggs, in order that he might obtain a good stock for market; nor do I see that there is anything blameable in making a collection of birds' eggs for a museum of natural curiosities by similar means.

"If you say, again, that such deceptions are likely to be injurious to the character of young persons, I answer, that a very young child can be taught the difference between deceiving his parents, and deceiving brute animals. Perfect sincerity and truthfulness is his bounden duty towards all his fellow-creatures, but it is by his superior wisdom and skill in deceiving mainly; not by superior strength, that he has dominion over the inferior animals. What is a mouse-trap, or a fishingnet, but a deception? Does not the groom deceive the horse when he holds out to it a sieve full of oats, and, while it is eating, flings the halter over its head? Does not the child deceive when he entices a dog into a certain 


\section{BIRDS' NESTS.}

room by offering it food, and then shuts it in? A child may be taught that all these things are allowable towards brute animals, and still may be trained up to the habit of treating his companions as he would wish to be treated by them."

Nothing further of consequence occurred during the remainder of the walk, and when they reached the village, Mr. Miller stated his intention of calling first at Johnson's cottage, though he thought it scarcely likely that he should find the father at home at this hour.

Johnson's cottage, though prettily situated, was by no means a tempting one to enter. It stood by the side of the road, with some beautiful trees behind it, and a sloping garden in front, which might not only have been made very neat, but, if properly cultivated, have been made profitable: as it was, however, it was little better than a piece of waste ground. There were to be seen some traces of beds, with two or three fruit-trees loaded 
with blossom, and showing that the soil was productive enough; but the ground had not been turned since last year's crops were taken off; a few broken sticks yet standing in a row, showed where there had once been kidneybeans; and a cabbage-stump here and there, trodden down into the mud, supplied the place of the young plants which ought at this season to have been beginning to supply the family with vegetables. The wicket gate had lost one of its hinges, and hung half open; and on each side of the house there was a broad gap in the hedge, clearly proving that any one going to or from the house saved himself the trouble of opening the rickety gate by passing through the gap either to the right or left, just as he happened to be going up or down the hill. Just in front of the door was a pit, filled by the heavy rain of the previous day with water, which five minutes' work with a spade or hoe would have drained off. A flat stone in the door-way was so loose, that, 
as Mr. Miller stepped on it, it splashed the filthy water on all sides, and it was quite clear that the puddle had been suffered to remain so long that it had washed away the earth from beneath the stone, and made its way beneath the tile floor within. Indeed, in more than one place a tile had sunk an inch or more, so that the black slimy mud oozed through in several places. The door stood wide open, and just inside sat the younger Johnson, dipping up the filth with an iron spoon, from one of the little pools, and pouring it into another.

The unhappy child looked very much frightened when he spied Mr. Miller, and to the question, "Is your mother at home?" made scarcely any reply, but skulked to the door, and made his way through one of the gaps as fast as he could.

This gave Mr. Miller time to look around him, and it need hardly be said, that the contrast between this unsightly dwelling and the 
lovely order of nature which he had been contemplating, was painful in the extreme.

The room was wretchedly furnished, and of the few things that were in it, nothing seemed in its place. There was a dresser, but most of the nails for hanging cups and saucers on, had been taken out, perhaps to mend the rickety chairs, or to nail together the two pieces of a leg of the table. One of the chairs had no back, and another wanted a leg. The table had all its four legs, but there was no part of the room where they could possibly be made to touch the floor all at once, so uneven was it. On the lower shelf of the dresser stood a very dirty saucepan, and on the upper ones were a shoe, a pair of bellows without a snout, a dirty cap trimmed with crumpled flowers, and a few other such things. The two drawers of the dresser were open, as if some one had been looking for something, and had not taken the trouble to close them. One of them was nearly filled with rabbit-skins; 


\section{BIRDS' NESTS.}

but the contents of the other it would be very hard to describe.

It appeared that the family had not long dined, for on the table stood a Jarge brown pan, to the sides of which there yet stuck some bits of greasy potato, which a cat had been prevented by Mr. Miller's entrance from finishing. There was no cloth on the table, nor were there any plates or forks; two or three very dirty knives and iron-spoons were the whole of the dinner-service. The windows matched well with the rest of the house, dirty, cracked, and without curtains; and across one of them was hung a string of birds' eggs, a melancholy sight anywhere, but doubly so here; because the wretched condition of all around, proved that the person who took them could not possibly have had an eye to their elegance of form or beauty of colour, and so have lost sight of the cruelty of robbing the nests. Mr. Miller could not help saying, "What a pity that Mrs, Johnson, instead of 
encouraging her sons to rob nests, did not go to birds for a lesson in neatness, patience and industry, yes, and carefulness too in bringing up her family! Don't you think, Henry, that a wren may be as happy in her hole of a nest, as you would be here?"

Before an answer could be given, the mistress of the house made her appearance.

"I am afraid, Sir, that you think me a very dirty woman ;" said Mrs. Johnson, as she proceeded to wipe with her apron one of the chairs which seemed somewhat less crazy than the rest.

Now, though Mr. Miller had no intention of beginning the conversation by remarking on the untidy condition of the house, he was far too honest to say that it was not dirty, and too anxious for the welfare of the people about him, to suggest an excuse for culpable negligence; he replied therefore,-

"Why, indeed, I am sorry to be obliged to say, that it is rather dirty." Mrs. Johnson, 
having what she çonsidered a very good excuse in her own mind, was not a little annoyed that her visitor assented so readily to the opinion she had herself just expressed, and would have been better pleased if he had made use of a phrase which careless people are in the habit of making to each other, and which she had often employed herself :- "I suppose it is not worse than the cottages of many other poor people." This defence, however, she held back for the present, and replied in a very long speech, the substance of which was:- "That gentlefolks knew little what hardships the poor had to put up with, and if they did not see everything as clean and neat as their own drawing-rooms, set all the fault down to idleness and carelessness. Her husband was a hard-working man with only ten shillings a-week, and out of that they had to pay two shillings a-week for the rent of their wretched house and garden, though the water came up through the floor after every shower, and they 
did not get five shillings'-worth of vegetables out of the garden all the year round."

"Certainly," said Mr. Miller, "eight shillings a-week does seem very little to clothe and feed a family, but I should think your eldest boy was able to do something to maintain himself by this time; and most of the women get well paid for their work at the time of sowing beans and potatoes, as well as at hay and corn harvest."

"Well, Sir, I suppose I don't earn less than my neighbours, for that matter; but what is that trifle, when you have to set against it the bill at the shop for tea, and candles, and soap, and such like?"

Mr. Miller thought that the sum expended in soap must be very small; though he did not say so; but added, "I thought your landlord did not require his rent to be paid every week, but called for it only once a-year, at the end of harvest, when his tenants can best spare the money?" 
"Yes, Sir, and so he does. Many's the time I have said how hard it is, that, after toiling and moiling as we do all harvest-time, from daybreak till you can't see your hand, all our earnings should go to pay for this dirty hole."

"Well, really I cannot see that your landlord treats you hardly at all. He has laid out a good deal of money on this house, I know. The walls and roof are very good, the windows were in good repair when you first came here, and the garden-ground is as good as any in the parish. It seems to me very reasonable, that he should expect to have his rent, and if he consents to receive it once a-year out of your harvest-money, it is for your convenience and not his."

"O Sir, I know you gentlefolks can always make it out very plainly, that poor people always spend their earnings in drink and fine clothes. I dare say you think my husband. goes to the alehouse; but I can say what a 
good many can't say, that he has not spent a penny in drink since Christmas."

Mrs. Johnson intended to finish the conversation with this speech, which she imagined her visitor must consider a triumphant defence. The fact was, that she had run up a long bill at the village shopkeepers' more than two years ago, and had promised so often to pay it, at one time with hay-money, and at another with harvest-money, without keeping her word, that the shopkeepers had at last refused to let her have a single article more without paying ready money; and had moreover threatened to sue her husband in the county court, unless she paid two shillings a-week, till the whole sum due was paid off. 'The consequence was, that Johnson had no money which he could spend at the public-house, so that his wife's statement that he had not spent a penny there since Christmas, sounded as if it were true. He had not, however, ceased to go there, or to drink there. A long score stood against 
him, which he was every week making longer. Already it nearly equalled the sum which it was likely that he would receive at harvest, and it was pretty certain that either the landlord of the cottage or the landlord of the White Horse, would be a loser. It was not possible to excuse Mrs. Johnson on the plea that she did not know this ; for being as fond of drink as her husband, she was in the habit of going to fetch him home in the evenings, but rarely returned till she had herself taken enough to add considerably to the score, which was running up in his name.

Mr. Miller knew nothing of this, though, as he could only suspect that he was being imposed on, he could say no more on the subject, but having added, "Well, I am pleased to hear so good a report of him ;" went on to say, "If I were he, I should employ a spare hour or two in draining off the water from that puddle before the door. You would then have a dry floor to your cottage, which I should 
think would then be more comfortable and healthy than it can be at present."

"Well, Sir, and so he would; but he says, and I say too, that that's the landlord's business, and he won't do it unless he is paid for his time."

"I can't see that it is the landlord's business. He made the house comfortable before you came into it, and it is the business of the tenant to keep it so. But even if the landlord were the person who ought to do it, it seems to me that it would be better to work three or four hours for him without being paid, rather than paddle about in the mud half the year round, and run the risk of getting fever and rheumatism into the house."

"Yes, Sir, and if we were to do that, he would be expecting us next to buy thorns and mend the gaps in the garden-hedge, that his cattle made."

" If Mr. Long's cattle broke through your fence, he certainly ought to make it good again; 
but still your wisest plan would have been to have bought a few thorns and repaired it, before you had let the time slip by for cropping the ground again, and trusted to his making an allowance out of your rent. You surely cannot expect him to pay for the loss of any more than the cattle actually destroyed, so that the loss of the coming crop must fall upon you. Have you told Mr. Long what mischief his cattle have done?"

"I have not told him myself; but I have sent over my eldest boy two or three times, though I am not quite sure whether he has taken the message. He is very busy birds'-nesting just now, and I think it very likely he has stayed about and forgotten it. Miss Mild has promised to give him twopence a dozen for eggs to ornament her new summer-house, * and I don't like to interfere with his little gains."

"I am very sorry that Miss Mild, or any one else that ought to know better, should * A fact. 
encourage him to spend his time in so idle and cruel a work; but it was about this I called to speak with you to-day. When was it that you last sent him to Mr. Long's?"

"Last Tuesday."

"That was the very day I caught him and his brother in my orchard, cutting one of my apple-trees."

"Oh, I heard him say that some one had made a great fuss about his trespassing and coming after apples; but for my part I can't see any great harm in the poor boy's just going into a wood or an orchard at this time of the year. It's few amusements that poor folks have at any time, and it seems to me very hard that they should be grudged those few."

"Well, Mrs. Johnson, I find I shall have very little chance of teaching your boy that it is wrong to break down fences and commit trespasses, if you make excuses for him in that way. I warn you, however, as I have warned him, that even if his intentions in breaking 


\section{BIRDS' NESTS.}

into my orchard were as imnocent as you think them, he has made it easy to come again for other purposes. I trust you will never have cause to lament, that when you taught him to say, 'Lead us not into temptation,' you did not also teach him not to run into temptation."

With these words Mr. Miller ended the conversation, and picking his way carefully through the mud and filth which lay around him, resumed his walk.

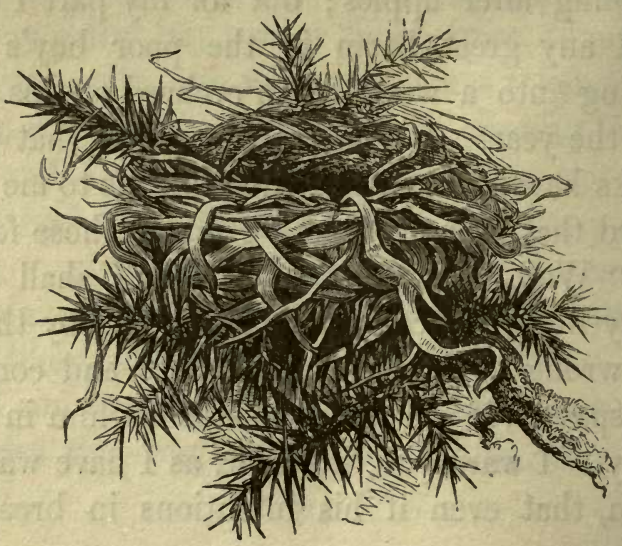




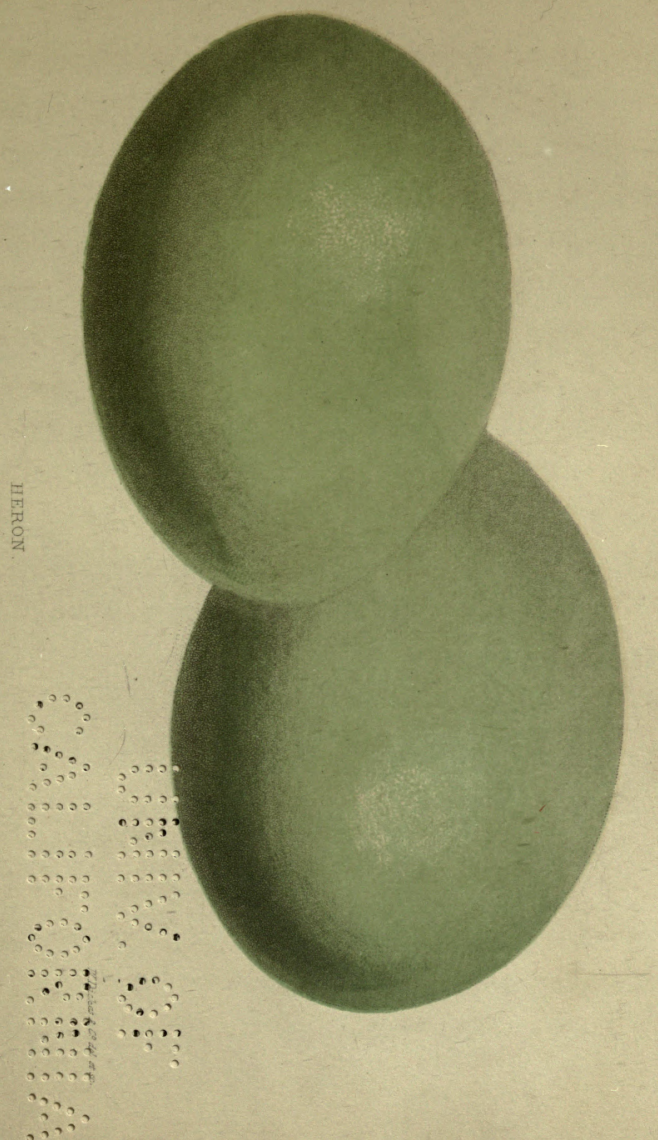





\section{CHAPTER X.}

UNIFORM BLUE OR GREEN, WITHOUT SPOTS.

\section{Heron.-Ardea cinerea. \\ Plate X.}

THe Heron is a social bird, building, like the rook, among the topmost branches of lofty trees, and always in company with other birds of the same kind. Its nest is built of sticks, and lined with wool. The eggs, four or five in number, are of a uniform sea-green colour, about two inches and a quarter long, and one inch and three quarters broad.

'SmÄ̈LING.-Sturnus vulgaris. 2...

DERING ihe autumn and winter, Starlings are racely to be seen alone. Sometimes, indeed, ihey iorm flocks so enormous, that they 
have been known to destroy plantations by simply alighting on the young branches. In spring, however, this society appears to be dissolved by common consent, and henceforth they rarely meet together, except to squabble about the possession of some choice situation for a nest. This is usually placed in holes of buildings, under eaves, in hollow trees, or, much to the annoyance of the inhabitants, in shoots of houses. It is made of slender twigs, straw, roots, and dry grass. The eggs are four or five in number, of a uniform delicate pale blue, and about an inch and a quarter long. The young, when first fledged, have little of the appearance of the old bird, being of a greyish brown colour withut the metallic lustre, or numerous spots, which distinguish the adult bird. In this stage, the young bird has been called the "solitary thrush;" but that it is not a distinct spiecies, is clear from the fact, that in a féw weeks it begins to assume the adult plumage, which 
appears, intermixed with the first feathers, in irregular patches.

\section{WhEATEAR. - Saxicola Enanthe. Plate XI. Fig. 2.}

\section{THe Wheatear is a bird of local occurrence,} confining itself principally to downs and commons, especially in the vicinity of the sea. On the rocky coast, it conceals its nest in the bottom of a deep recess in a cliff. Inland it makes its nest in old walls, or in pits from which stone, gravel, sand, or chalk have been dug out. A deserted rabbit-burrow is a favourite locality, and it is said it may frequently be detected in such situations by a heap of small pieces of the withered stalks of the brake-fern, made on the outside of the burrow. The nest is often concealed with much art; and at other times it is placed, without much attempt at concealment, under a clod in a fallow field. It is constructed of dried bents, light twigs, intermixed with 
feathers or rabbits' down. The eggs, from four to six in number, are of a uniform delicate pale blue, nearly an inch long, and somewhat above half an inch broad.

\section{Whinchat.-Saxicola Rubetra.}

६

Puate XI. Fig. 1.

THe Whinchat, or Furzechat, builds a nest very like that of the wheatear, and, like that bird, either on the ground, or a short distance beneath it. The nest is formed of moss and bents, and lined with fine grass. The eggs, five or six, are of a uniform bluish green, often marked with minute specks of dull reddish brown. The egg is three quarters of an inch long, and about half an inch broad.

REDStaRT.-Phonicura ruticilla.

\section{Plate XII. Fig. 2.}

ThIs pretty little bird selects for its dwelling a hollow tree, or a hole in a wall, or the space left between a fruit-tree and the wall to which it is trained; it has been known 

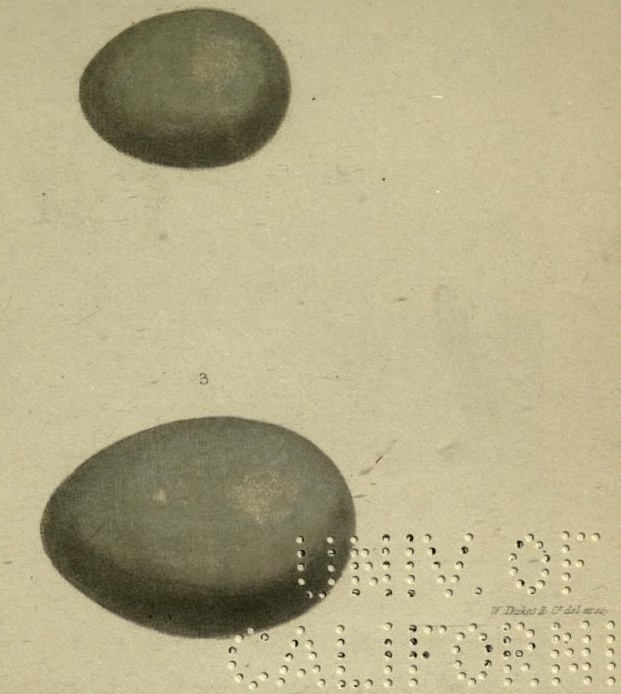

1. WHIICHAT

2. WHFIAT-EAR 


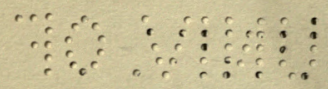


also to build its nest in a hole in the ground. A writer in the Zoologist has furnished the following notice of a singular locality for a redstart's nest :- "In the spring of 1841, I noticed that when I went to a particular part of my garden, a male redstart always appeared much distressed, which convinced me that its nest was near at hand; but I could not find it. One day, having occasion for a common flowerpot, not of a very large size, I took one which had been left inverted on a narrow path between two sea-kale beds. On lifting it up, I discovered a nest with five eggs, placed on the ground. I carefully replaced the pot over the nest, inclining it a little towards the south, so that when the sun was shining I could discern the eggs through the hole at the bottom (now, from its inverted position, the top) of the pot. On passing it soon after, I found the hen bird on the nest; and she succeeded in hatching and bringing up her brood, paying no regard to my looking down upon her as I 
passed by, if I did not stop." The eggs, from four to six, are of a bright greenish blue, without spot or any other kind of marking, about three quarters of an inch long, closely resembling those of the hedge sparrow, from which, however, they may be distinguished by their deeper colour and nearer approach to the spherical form.

Hedge Sparrow.-Accentor modularis.

\section{Plate XII. Fig. 1.}

This, perhaps, is the most frequently detected of all British birds' nests, and the one at which the young oölogist has first tried his hand. No sooner does the quickset hedge begin to bud, than the Hedge Sparrow lays the foundation of its nest in the centre of the thorny fence; and before the leaf has fully expanded, the bright blue eggs become even a more conspicuous object than the nest which contains them. The hedge sparrow, being a scarcely less fearless and confiding bird than 


\section{BIRDS' NESTS.}

robin redbreast himself, prefers the neighbourhood of the homestead to the open country, and too often, alas! suffers for his trustfulness. Every puny shepherd's boy considers its nest as his lawful prey, and, however short may be his stature, is able to make this at least his prize; for the hedge sparrow rarely builds above four or five feet from the ground. But though so many of these nests are destroyed, there appears to be no decrease in the number of the birds. The reason probably is, that they breed several times in the season; and as the leaf expands with the advancing spring, though their first efforts are open to detection, the succeeding ones are concealed within an impenetrable veil of foliage. The nest is composed of twigs, moss, and roots, felted together with wool, and lined with hair. The eggs, four or five, are of a uniform greenish blue, somewhat lighter than those of the redstart, and rather longer in proportion to their breadth. 
Nighringale.-Luscinia Philomela. Plate XXI. Fig. 3.

THe Nightingale, though unrivalled as a musician, can boast of no great architectural skill. It constructs its nest, placed either quite on the ground, or at the very base of a bush, of dry oak leaves, so imperfectly fastened together with bents and fine roots, that it is almost impossible to remove it without utterly destroying it. The eggs, usually five in number, are of a uniform olive brown, and but little larger than those of the hedge sparrow.

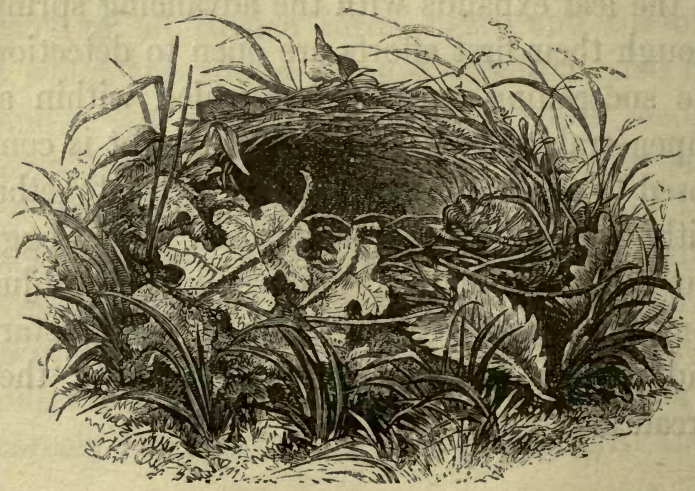



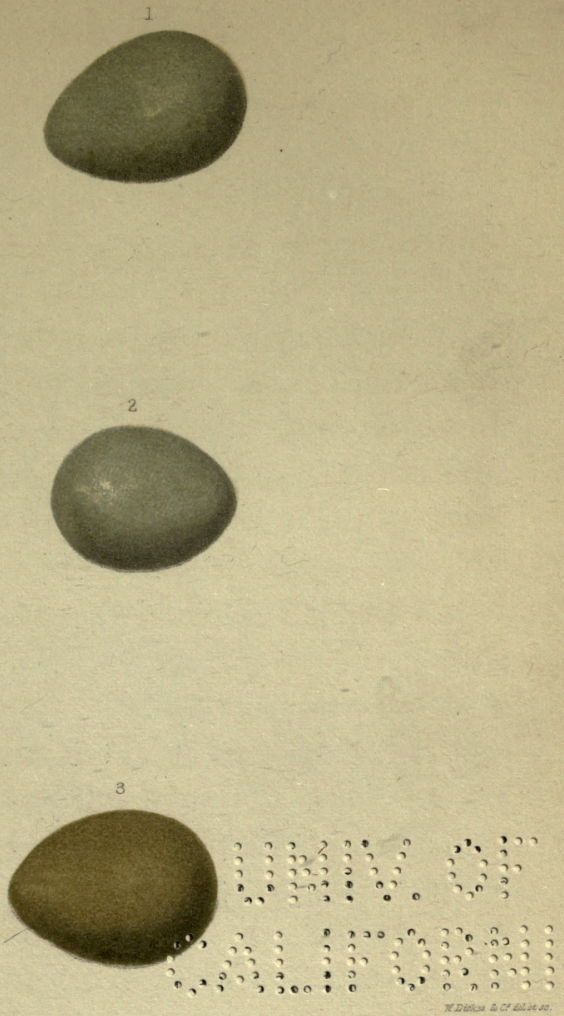

1. HEDGE SPARRONT.

2. REDSTART 


\section{CHAPTER XI.}

No greater contrast can be conceived than that which Mrs. Square's neat little cottage presented to the wretched dwelling they had just left. The house itself was smaller, and not so prettily situated. The garden in front was too small to be turned to any profitable account, but had not for that reason been neglected, being filled, perhaps too thickly, with stocks and wallflowers, and sweetwilliams, the first two in full flower, the last making great promise of blossom. A beautiful moss-rose-tree, covered with buds, was trained round the window on one side, and a myrtle was beginning to put forth its leaves on the other. The door stood open, and through the doorway a cloud of steam was pouring out, the smell of which, if not pleasant, was at all 
events wholesome, and, compared to the odour of Mrs. Johnson's house, absolutely fragrant. " Good morning, Mrs. Square; I am come again on washing-day, I see."

"Yes, Sir, and I hope you are likely to come again; for it is washing-day with me, I am thankful to say, every day except Saturday and Sunday. My business is so much increased, that I can find plenty of work five days in the week, though I hire a neighbour to help me." "I am happy to hear it; and, now that I think of it, I have some good news for you: the duty is to be taken off soap, so that you will have it much cheaper. Honest people, like you, will be the greatest gainers by the change; for I know that several persons send you their washing, because you never use any of the bleaching-powders which do so much mischief to the clothes; and now you will be able to wash with as little expense as those who do use them."

"That is good news, indeed, Sir; and now 
I hope bleaching-powders will go out of use. I never used but one paper a neighbour recommended me to try, saying that it would make the things much whiter; so I tried it on some of my own clothes first. Sure enough it made them very white at first, and with half the labour; but, after a few times, I found them wearing into holes, though they were nearly new."

"You acted very wisely in seeing how the plan answered before you tried it on your neighbours' property, and honestly, in preferring the extra trouble to breaking the rule of doing to others as you would have them do to you. Is your little boy at home?"

"I expect him in every minute, Sir; he is only gone to the village on an errand. I was very grieved to hear, the other day, that he had been found birds'-nesting in your orchard. He came home in great trouble, and told me all about it; and I gave him a good talking to. He was very much afraid that you would take 
away your washing from me in consequence; but I told him that if you had promised to forgive him, there was no fear of that. It all came of his being disobedient, and going about with Bill Johnson."

"That is just what I wanted to talk to you about; but here comes Joe himself."

The boy now entered, and seeing Mr. Miller, looked confused, if not frightened.

"Come in, my little man," said Mr. Miller, " and don't be afraid. Your mother said, quite truly, that I did not mean to punish her for your offence. Your first and greatest fault was making a companion of a boy of whom she disapproved; the offence against me, as it happened, was very trifling. But I mean to say no more about it now. I dare say you are sorry for both the disobedience and the trespass, or you would not have confessed it to one who you knew would reprove, and perhaps punish you. Now run away, and show Henry your mother's garden." 
Joe stammered out a few words, which were intended to mean that he would take good care for the future, and went off, nothing loth, with his young companion.

As soon as the boys were gone, Mr. Miller thus resumed the conversation :

"Now, Mrs. Square, you know I am not much given to tale-bearing, or to listening to stories of other people's wicked doings; but where there is good reason to believe that a neighbour is likely to be injured by associating with a person of bad character, it is a positive duty to put him on his guard. Your boy, I fear, is learning no good from young Johnson, who, to the best of my belief, is an idle, good-for-nothing fellow; and I don't think you can be too strict in forbidding Joe to have anything to do with him."

"I am afraid, Sir, that what you say is too true, and I am very much obliged to you for giving Joe the advice you did; for though he is a good boy in the main, and would not, 
I believe, do anything wrong, if he thought about it beforehand, he is giddy, and likely to be led astray before he well knows what he is about. I have often told him to have as little as possible to do with Johnson, and he tells me he had not spoken to him for a fortnight before the day you caught them in your orchard. Johnson joined him that day as he was walking along the road, and persuaded him first, to look for nests in the fields, and then in Mr. Long's rookery, and at last they came to your ground; but I hope they did not get into any mischief. He has been here once since that; but Joe would not go with him, even if I had allowed him. Some one, they tell me, has been stealing pheasants' eggs, and selling them. The keepers are looking out sharply, and I heard to-day that Johnson is suspected of being the thief."

"I trust," said Mr. Miller, "that he has not committed any act of decided dishonesty; though, as I tried to convince him, the habit 
of breaking fences, and going into places where he might steal if he chose, is likely to lead him into sad temptations. I see, however, that it is not necessary for me to impress on you the necessity of forbidding Joe to keep company with him, so I will not keep you any longer from your washing, but wish you a good morning."

With these words Mr. Miller left the house, and calling his son, they were soon on their way homewards.

"And in what state did you find Mrs. Square's garden?" asked Mr. Miller. "Are her crops in better order than Mrs. Johnson's?"

"Why, papa, I forgot to look; for Joe told me he could show me some nests, and when I had seen them I thought you would be waiting for me; but I think it was very orderly. I know she has a large bundle of bean-sticks under a shed, saved from last year, ready for sticking when the time comes, for Joe showed 
me a blackbird's nest in them, with five eggs in it."

"It was very wise of Mrs. Square to save them. Good bean-sticks cost a good deal of money, and will last for three years, if taken proper care of. But poor people are very much in the habit of letting them stand in the ground till they are rotten. They then break them up and use them for firewood, though half the money that they cost would purchase a larger quantity of serviceable faggots. And what did you see besides?"

"Joe took me to an open place in the garden, and asked me to look round and see if I could find a nest. I looked all round, but there was not a bush nor a hedge near me, so I soon gave it up, and he showed me a dear little robin's nest built under a wisp of straw which was lying on the ground. It was the very last place I should have thought of looking for one, and I am quite sure I should have passed it by twenty times without finding it. 
The old birds know that Joe has found out their hiding-place; but they don't mind him a bit, for they carry in grubs and insects to their young, while he is standing close by. He says he should not have found it if he had not seen the old bird fly in, carrying a feather in its mouth. Joe showed me another nest besides this; he says he thinks it is a nightingale's nest."

"In what sort of a place is it built?" asked Mr. Miller, "and what is it made of?"

"Oh, it is built of scarcely anything but dry oak leaves, and seems so loose that I don't know how it stays together; and it is in a thick hedge, a very little way from the ground. There are no eggs in it yet, but when there are, Joe says I may have one of them. May I, papa?"

"Judging from your description, I suppose the nest must be a nightingale's. The eggs, however, will tell you to a certainty, as they are unlike those of any other English bird, 
dark olive brown, almost like bronze. It seems almost a pity to take the egg of such a songster as the nightingale, and so to have one bird less next summer; but as your collection will not be complete without one, I suppose I must say yes, provided that Joe does not consider that a reason why he should take the rest."

"Oh, no, papa! Joe does not collect eggs now; since the day we took the nuthatch's nest, he says he has not taken any nest, and he says the eggs are of no use to him. He asked me if I had a rook's egg, and told me such a funny story about one."

"And what may that have been?"

"He said that the same day he came to our orchard, Bill Johnson wanted him to go with him to Mr. Long's rookery, but that he was afraid, so Johnson told him to wait outside while he went in. The rookery, you know, is in the park, but close to the road, so that he could see very well through the hedge what was going on inside. Johnson climbed to the 
top of one of the trees which was easier to get up than the rest, and after taking a great deal of trouble he reached a nest, and found one egg in it. He took this and was coming down again, but as he had to use both his hands to prevent himself from falling, he could only carry the egg by putting it in his mouth. Before he had got half way down, he had to swing himself from one branch to another, and in doing this, somehow or other, he jerked himself so as to break the egg in his mouth. It would not be a very nice thing to break a fresh egg in one's mouth, but this was a great deal worse, for it was addled. Joe saw him sputtering and making wry faces, but he did not know what was the matter until he had come out of the park. The taste was so horrible that he was obliged to fling himself down and roll on the ground, though I don't know what good that could do him. At last he filled his mouth with earth, for there was no water near; but he could not get the 
180 BIRDS' NESTS.

taste out of his mouth for an hour or more."

It is no doubt a most unkind thing to do, to laugh at another person's distress; yet Mr. Miller could not help thinking that the accident was just of that kind that the mischievous boy deserved to meet with, being one which caused him a good deal of inconvenience at the time, but was attended with no permanent injury. Had he fallen and broken an arm, or a leg, he would have been among the first to offer assistance, and would have instantly checked his son, had he shown any inclination to speak lightly of the sufferer. But that an impudent boy, who had broken through a park fence, and attempted to steal eggs from a private rookery, should be punished through the instrumentality of an egg, seemed so just a retribution that he did not hesitate to join in the laugh. He therefore added,-

"I think that Johnson was punished as he deserved, and I should be very glad to believe 
that he was likely in consequence to alter his mode of life. But I am very much afraid that we shall hear before long of his having done something which will bring him into serious trouble. There is, I am told, a strict watch being kept upon him, and if he is caught out in what he is suspected of, he will find it a much graver affair than being caught in my orchard."

They had now reached the place where the nest of eggs had been hid away, and having easily found them, resumed their walk, which they finished without meeting with any further incident worth mentioning. 


\section{CHAPTER XII.}

EGGS BLUE OR GREEN, SPOTTED.

Raven.-Corvus Corax.

Plate XIV. Fig. 2.

Like most other large birds building early in the season, when there is no friendly foliage to conceal their labours, the Raven usually places its nest, where, however exposed it may be to the gaze of the passer-by, it is most difficult of access. In a forked branch of some lofty tree, or in the niche of a precipitous cliff, the raven builds a substantial structure of sticks and roots, lined with wool and hair. Though not generally noted for its amiability, or in fact for any other good qualities, the raven displays a strong attachment for home. When it has once taken possession of a 


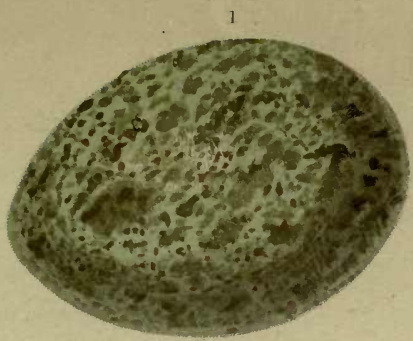

2

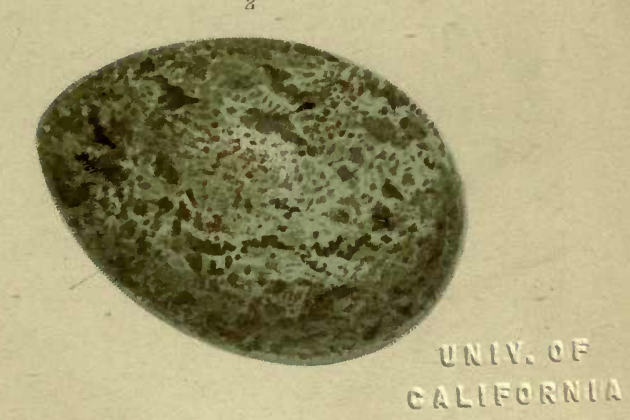

1. ROOK .

2. CROW. 


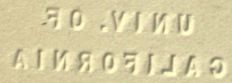


locality, it rarely deserts it, but returns year after year. Should one of a pair chance to be killed, the survivor finds a new mate, and, strange to say, if both be destroyed, the nest usually finds a new pair of occupants in the following season. The eggs are four or five in number, two inches long, of a pale green, spotted and speckled with darker greenish brown.

\section{Rоoк.-Corvus frugilegus. \\ Plate XIII. Fig. 1.}

MaNy singular localities of Rooks' nests are noticed by ornithologists ; such, for instance, as the spire of a church in the heart of London, or the vane of the Exchange in Newcastleupon-Tyne, in which latter situation a nest was constructed annually for ten consecutive years, and was whirled round with every change of wind. It would not, however, be correct to name such situations as the natural places of resort of these birds. The fact is, 
184 BIRDS' NEST'S.

that the rook possesses a strong attachment for the place in which it was reared, and, failing trees, its natural abode, puts up with great inconvenience rather than desert its early haunts. A rookery is so familiar a sight to every one who has eyes, and can use them, that any description would be quite superfluous. The nest is built of sticks, often of large size, and lined with grass and fibrous roots. The eggs, four or five in number, are of a pale greenish colour, blotched with dark brown.

Rooks appear to be somewhat capricious in selecting the site of a new colony, but it is said that they may be induced to establish themselves in a grove or wood by substituting their eggs for those of a crow or magpie which may happen to have built its nest in the neighbourhood. The young birds having no attachment for any other place, will return the following season, and build their nests where they were reared. 

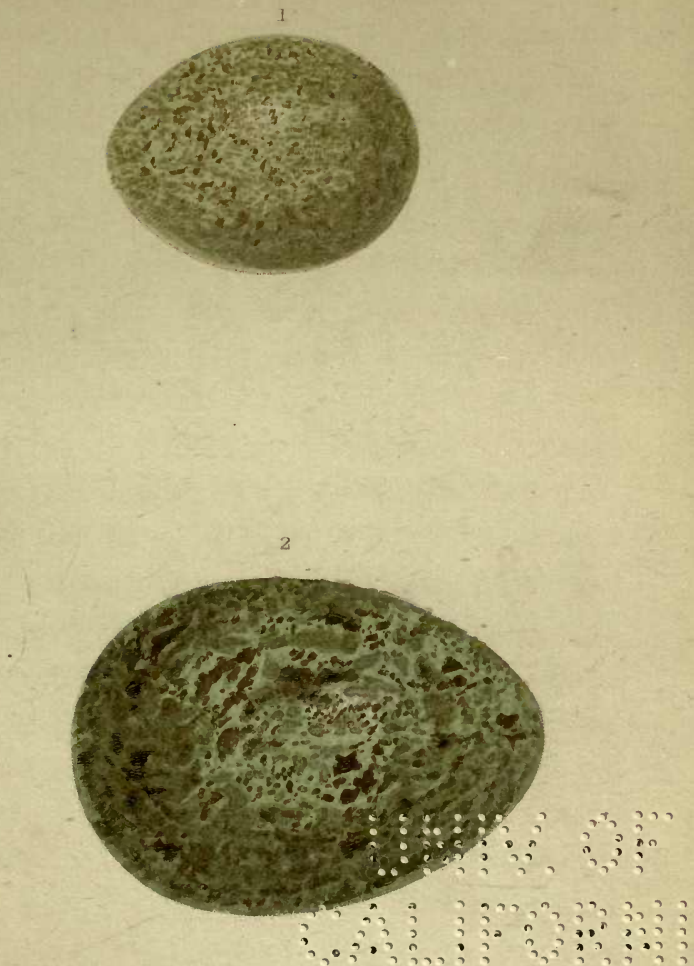

1. MAGPIE. 2. RAVHN. 

BIRDS' NESTS.

\section{Crow.-Corvus Corone. \\ Plate XIII. Fig. 2.}

THE nest of the Crow much resembles that of the rook, but is more frequently placed in the fork of a tree than among the topmost branches, and is always solitary. The eggs are of a pale bluish green, spotted with ash colour and brown.

\section{MagPie.-Pica caudata. Puate XIV. Fig. 1.}

The nest of the Magpie resembles in shape that of the wren, but is constructed of very different materials. Conscious, perhaps, of his natural propensity to cunning and plunder, he is aware that his character is not held in very high estimation, and that consequently he is liable to be called to account for petty larceny, at least, if not for open robbery. He therefore establishes himself in the centre of some thick thorn-bush, or high up in a tree, which his sharp eye has discovered to be difficult of 
access. Here he collects a vast quantity of sharp thorny sticks, which he weaves together with consummate skill, as if, indeed, he had been all his days practising the harmless profession of a basket-maker. His house, when finished, presents the appearance of a huge ball of spines, as proof against injury as an angry porcupine. One small hole only in the side is left undefended, through which, the bandit, while at home, keeps a steady watch, and if danger approaches, makes off as rapidly as if every intruder were a policeman. The magpie lays six or seven pale blue eggs, spotted with ash colour, and two shades of greenish brown. These are nearly an inch and a half long, and an inch broad.

\section{JAY.-Garrulus glandarius. Plate XV. Fig. 1.}

There is nothing remarkable in the nest of the Jay; it is usually built in a low bush, or in the fork of a tree in a wood. The founda- 


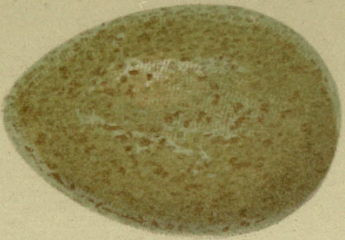

3

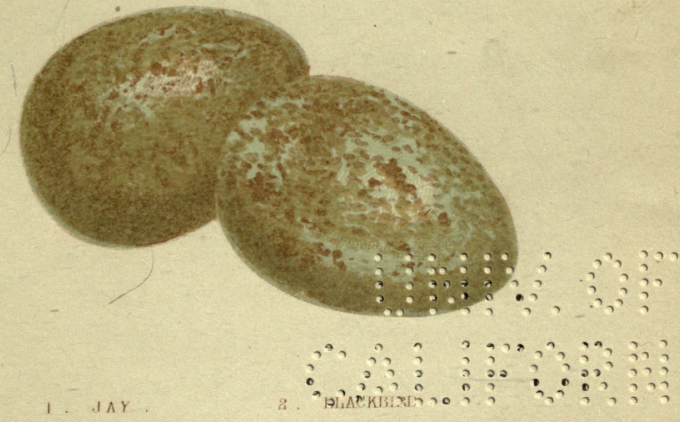


tion is of small sticks, and the substance of the nest is composed of fine roots with a lining of grass. The eggs, usually five, are an inch and a quarter long, of a greenish tinge, copiously speckled with minute brown specks, which often form a ring towards the larger end. The egg is small in proportion to the size of the bird.

\section{Bi_ACKBIRD.-Turdus Merula. Puate XV. Fig. 2.}

THe Blackbird constructs its nest very early in the season, selecting sometimes a fence of dead brambles, sometimes a quickset hedge, an ivy-clad ruin, an evergreen, or sometimes a solitary bush so much exposed to the public view that one would think the owner indifferent whether it escaped detection or not. As the blackbird begins to sit long before genial spring weather sets in, its eggs require more than ordinary protection from the cold. This 
object the bird attains by building a very substantial nest, laying first a good foundation of small sticks and roots; this outer fence it then plasters with a thick layer of mud, and lines the whole with dry grass. The eggs are four or five, of a dull bluish green, copiously speckled with reddish brown. The number and size of the spots vary exceedingly in different specimens; sometimes they are minute, and so close together, that the ground is almost concealed; in other examples, the spots are larger, and the ground of a brighter hue. Some specimens closely resemble the egg of the jay, from which, however, they may be distinguished by. their redder hue, and somewhat smaller size. The nest and eggs of the Ring Ouzel (Turdus torquatus), are very like those of the blackbird, but the former is most usually built upon a ledge of rock, sometimes on banks by the sides of streams, or among heath, or occasionally at the base of a stump or bush. 


\section{Thrush.-Turdus musicus. \\ Plate XVI. Fig. 3.}

The Thrush places its nest in nearly the same situations as the blackbird. The outside of the nest is composed of small sticks and fine roots, interwoven with green moss. The inside is plastered with a composition of rotten wood and cow-dung, which, when dry, forms a shell of so close a texture as to be impervious to water. The eggs, four or five in number, are about an inch long, of a beautiful bright blue colour, and sparingly marked towards the larger end with well-defined black spots, A further account of the thrush's nest will be found at page 35 .

\section{Bullfinch.-Pyrrhula vulgaris. Plate XVI. Fig. 2.}

The nest of the Bullfinch must be searched for in a shrubbery of evergreens, an ivy-covered 
wall, or the hedge of a wood. It is formed of small twigs and moss, and lined with fibrous roots, not so carefully put together as is the case with many others of the finch tribe. The eggs, four or five in number, are of a delicate pale blue, speckled and blotched with light red and dark purple.

\section{Stonechat.-Saxicola rubicola. Plate XVI. Fig, 1.}

THe Stonechat builds its nest in the commons or open downs, which it frequents during the whole of the year, selecting a low bush -usually furze. The nest is constructed of moss and bents, lined with fine grass and feathers. The eggs, usually five, are light grey, faintly speckled near their larger end with a reddish brown. They are readily distinguished from those of the whinchat by being much less blue, and more closely sprinkled with spots. 

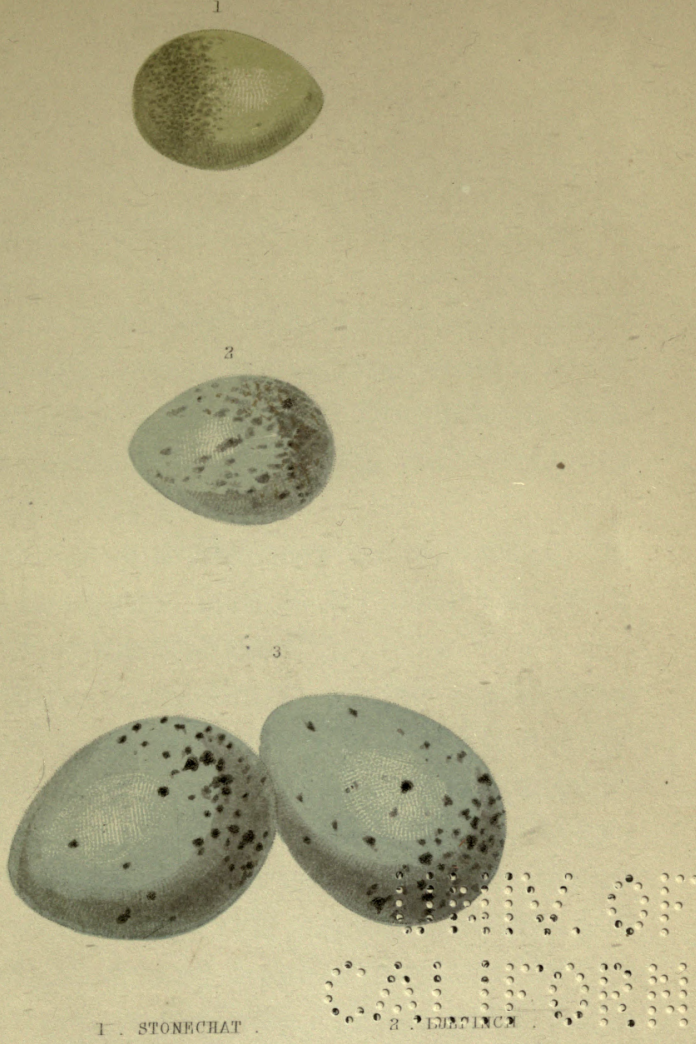

3. THRUSH. 



\section{CHAPTER XIII.}

Aвоuт a week after the visit to Mrs. Johnson and Mrs. Square above mentioned, Henry came running in again from the orchard with his face beaming with delight, and screaming at the top of his voice,-

"Papa, the nuthatch has come back to its nest; I have just seen it fly into the same hole. Do come and see!"

Mr. Miller immediately left his books, and proceeded to the orchard. He dealt a few sharp taps on the trunk of the tree, and sure enough out flew a bird, which immediately perched . among the boughs of a neighbouring tree, clinging to the branches in all possible attitudes, and twittering in a very familiar manner. It was not, however a nuthatch, but a great tit, a very pretty bird, with a black head and yellow 
breast, marked down the centre by a dark line.

The ladder was again sent for, and Henry having eagerly mounted it, thrust his hand into the hole, and produced an egg of about the same size as the nuthatch's, and of the same colour, but marked with smaller and lighter spots. There were three or four eggs in the nest, but one only was taken, and the nest was not disturbed any further, so that it was not known how many were laid. In due time, however, they were hatched, and a family reared. There was nothing remarkable in the fact that the bird should have selected a spot which another bird had deserted; but it was very surprising that the tit should have found out the place so soon after the nuthatch had deserted it, have finished a very neat nest, and laid several eggs, all within ten days. Sparrows often build in martins' nests, and hawks in crows'; but these are old nests. Here, however, the new comers must have set to work 
almost the very day that the old inhabitants left it, and took less time probably in finishing their house, because they were able to use the fresh materials which the nuthatches had collected.

The eggs were carefully put away in the cabinet, and a note was added to the index, stating that they were both taken from the same nest, added to which was the date of the very day on which each prize was made.

By this time a thrush, which had built her nest in the fork of a laurel, quite close to the garden gate, had hatched her eggs, and was busily employed in rearing her brood. Notwithstanding the frequent goings in and out of visitors, she never appeared frightened, and would go on with her feeding, even when Henry stood close by watching her. At last he thought of feeding her while she sat brooding over her young, and to his great delight found that she cheerfully accepted his hospitality, snapping eagerly from a forked stick 
small bits of raw meat, or, when that delicacy could be procured, a worm. As the young birds acquired their feathers, he watched her with great interest teaching them to fly, though one of them made so bad use of his newly-acquired power, as, the first time he made use of his wings, to fly into a cistern, where he was drowned before any one could rescue him.

But, before this sad event, a very singular thing happened. Mr. Miller was one morning walking in the garden, when he heard the repeated cry of a young bird, half in distress and half in anger. Looking down one of the walks he saw a young bird on the ground, standing quite still, but eagerly watching something hid among the bushes, and screaming with all its might. Walking up to the place to see what was the matter, Mr. Miller discovered that the object of the little creature's fear or anger was the cat, which stood among the bushes a few feet off, seeming herself 
scarcely less astonished than the bird. $\mathrm{He}$ clapped his hands, and the cat disappeared in one direction, and the bird scrambled away in the other. Mr. Miller could only account for this strange proceeding, by supposing either that the bird's angry clatter had really made the cat cautious how she touched it, or that finding it in the garden-walk, and near the house, in a place where a brood of chickens were sometimes allowed to run about, she had confounded it with one of them, and abstained from what appeared to her to be her master's property. However this may be, the courageous little fellow was saved from an early death. He did not go back to the nest, from which, perhaps he had fallen by accident, but he was often heard among the bushes asking in his way for food, and an old bird was frequently seen in his neighbourhood, and heard uttering the peculiar note with which some birds accompany the feeding of their young. Some other broods were not so fortunate. 

196
BIRDS' NESTS.

The young birds disappeared from the blackbird's nest one after the other, and that puss was the culprit here there was little doubt, as she was actually seen carrying away one in her mouth. A brood of hedge-sparrows in a hollybush, on the lawn, were found with their heads eaten off. This mischief was attributed to a stoat, which had been often seen crossing the lawn from the meadow, and running under the very tree in which the nest was placed. These little animals are supposed to be very destructive to birds which build their nests on or near the ground, both by sucking the eggs and killing the young. Indeed, when we come to think on the matter, there must be a very large number of birds annually killed by wild animals and other causes, or they would every year become more numerous. For, supposing each pair of birds to lay only four eggs, and to die in the following winter, (which certainly is not generally the case,) the number of birds belonging to any one sort 


\section{BIRDS' NESTS.}

would double itself every year; and if this were the case, they would soon become so abundant as to have to fight for places to build their nests. But they do not seem to increase at all. There appears to be just the same number of thrushes and blackbirds, of sparrows and chaffinches, that there was last year. What becomes of them? If they went away to foreign lands, we should hear of their appearance there. But other lands are stocked just as well as ours. We hear sometimes of a new kind of bird being found in a certain place, it is true; but that is usually a bird of passage, about whose ways we know very little. We can only account for the fact by referring all to the Providence of God, who, by various ways known only to himself, so directs the increase of animals, that they shall neither become so numerous as to interfere with each other, nor so scarce as to allow the earth to be overrun with weeds, the seeds of which are consumed by them as food, nor be stripped of its produce 


\section{BIRDS' NESTS.}

by insects which afford sustenance to thousands of living creatures.

'These, however, were not all the mischances which occurred to the nests near the house. Mr. Miller, walking through the wood, observed that the grass had been trodden down and the bushes bent aside in the neighbourhood of the pheasant's nest, as if some one had been paying it a visit. This excited his attention so far, that, contrary to his custom, he went up in order to examine it. He found that what he feared had taken place. Some poacher, prowling through the wood, had discovered the nest and carried off its contents. This was a great disappointment, for though the wood belonged to his neighbour, Mr. Long, he had looked forward with much pleasure to having a brood of these beautiful birds within a short distance of his house; not that he might shoot them, for he was no sportsman; but that he might watch their habits, listen for their curious crow in the spring, and occasionally be agree- 
ably startled as they suddenly rose from the thick underwood, and flew heavily to another part of the cover. This, however, was now out of the question, since the wood being a small one, it was not likely to contain another nest.

He searched carefully about, in hopes of finding something which might help to convict the offender, but without success. The ground was so thickly covered with long grass, bluebells, and other woodland flowers, that no footprints could be detected, and after a while he gave up the search. On regaining the path, he began to return homewards, when his attention was aroused by a little bit of something white sticking to a bramble. $\mathrm{He}$ picked it off, and found it to be the corner of what appeared to be a newspaper; and on examining the ground more closely, he observed that the plants had been recently pressed down, as if something heavy had been laid on them. The thought immediately occurred to him, that 
the thief, whoever he might be, might have stopped and laid down his prize here, in order to wrap it up in paper brought for the express purpose, so that he might carry it off without exciting suspicion, in case he met any one before he could get rid of his booty.

From the wood Mr. Miller repaired to a shrubbery yet nearer the house, to make sure of the safety of a favourite white duck, which had chosen to lay her eggs and sit on them in a place quite accessible from the meadow bordering the wood and garden.

Domestic fowls frequently take strange fancies. Sometimes they seem bent on laying their eggs all in one nest, in order that they may afterwards fight for the ownership of the whole; and very frequently they take so strong a dislike to laying in the place which has been provided for them, no matter how well adapted for the purpose it may be, that they will prefer any other place to which they can get access. A pile of wood, a haystack, a ditch, 
anything is thought better than the warm, dry hen-house, where no one is likely to disturb them, and where abundance of food is always within reach. Mr. Miller's poultry were very perverse. One hen had made her nest in the kitchen-garden, choosing a bed of carrots; another had wandered away into the wood, where she stayed for twenty-four hours together, and only came home to be fed; but what particular spot she had fixed on nobody could find out, though she had been watched many times. She had, however, made a wise selection, as it happened; for one day she was observed proudly walking up the meadow, with a brood of a dozen chickens at her heels. Another had taken it into her head that the highest place was the safest; so she had chosen a beam which went across from one side to the other of an old barn. She was not discovered until her eggs were almost ready to be hatched; and when this had taken place, the gardener was obliged to fetch them down 
one by one, by the help of a ladder. Whether the silly mother had formed any plan in her own head for getting down her chickens, never appeared. Perhaps it was her first brood, and she did not know that they would not be able to fly as soon as they were hatched, but thought that as she was able to fly up, they would be able to fly down to her, much the easier operation of the two. One of the ducks could find no place, either in the poultry-yard, garden, meadow, or wood, to suit her taste, but had scrambled through a thick hedge, and made her nest in a ditch, by the side of the road, over which carts, horses, and people, passed at all hours of the day. She always covered her eggs with dry leaves and rubbish whenever she left it, and so made it very difficult to find them; but it was clear that she must have always chosen some time for doing so when nobody was passing, or she would certainly have been observed. The gardener found her out before she had begun to sit, and took the 
eggs; so the next time she visited her nest, finding it empty, she went there no more.

Another duck, the white one mentioned above, had made her nest in a bed of periwinkles, not far from the house. Her white colour discovered her soon after she had begun to sit; but since it was not expected that trespassers would come into the garden, and she was tolerably well hid by the plants around her, she was allowed to retain her post undisturbed. She was very tame, and would not only allow any one to come close to her without moving, but if any one held out to her a handful of barley, would quickly gobble it up, without leaving her eggs. This fearlessness of strangers made Mr. Miller more afraid, that if, as he suspected, some dishonest person had been prowling about the place, both duck and eggs would have been carried off. A few minutes set the matter at rest. The plants were trampled down, the eggs gone, though, being within a few days of hatching, they were 
utterly useless, and the duck was no where to be seen. After a short search, her dead body was found lying among the shrubs; from which it was pretty clear that the thief had carried off the eggs, but was afraid to take the duck as well, lest he should be detected by the feathers.

There was great grief in the house when the story was told, and Henry particularly was very indignant with the culprit. "Poor duck," he said, "that used to be so tame, and let me feed it whenever I liked! What can they have killed it for, if they did not want it to eat? I wish we could catch the thief, and send him to prison. Papa! I do think Johnson must have done it."

"What reason have you for thinking that?" said Mr. Miller.

"Oh, I don't know, except that he is just the sort of fellow to break into any one's garden and steal eggs."

"I am afraid," replied Mr. Miller, " that 
there are too many of those who disobey God's commandments, both in that and other ways, for us to fix on any one as the culprit. Johnson, I dare say, would not shrink from breaking into a garden, more than into an orchard or a park; but you must remember that he has not been brought up to see any harm in robbing birds' nests anywhere. It would be unjust, however, to take it for granted that he would steal ducks' and pheasants' eggs, which are private property, because he does not scruple to take the eggs of a thrush or blackbird, which can scarcely be said to belong to any one, or to which no one at least lays claim. Therefore, though you may suspect Johnson, in your own mind, you have no right to injure him by naming your suspicions to a single person, not even to me, unless indeed you have a good reason, which you say you have not."

Henry could not but see the justice of this remark, and said no more, though his thoughts still ran in the same direction; and to tell the 
206 BIRDs' NES'TS.

truth, Mr. Miller himself was convinced in his own mind that the same person, partly from daring, partly from revenge at being caught in the orchard, and still more, perhaps, from the hope of gain, had stolen both the pheasants' and ducks' eggs. How far he was right, we shall see by-and-by.

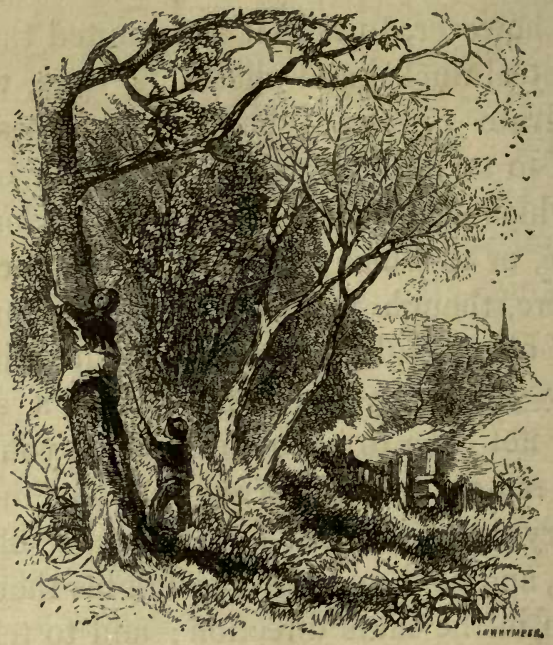



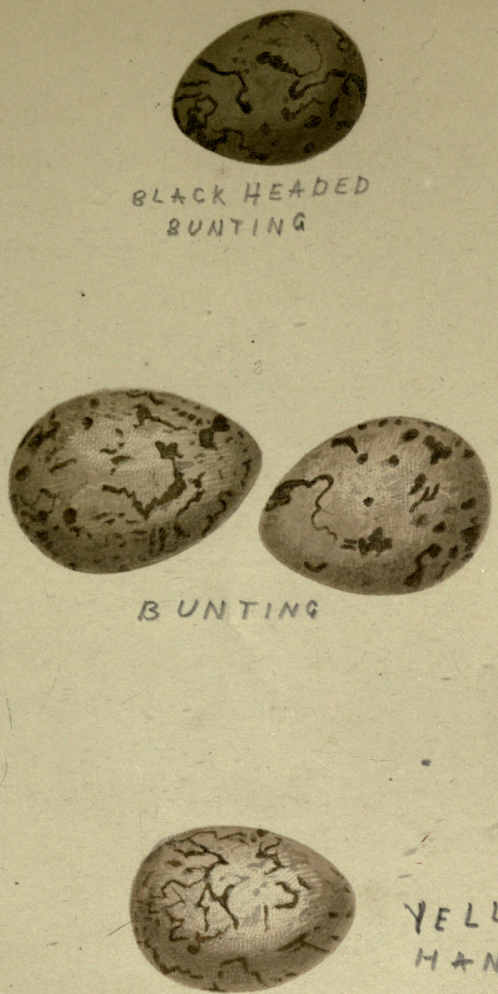

$Y E L L O W$
$H A M M E R$

UNIV. OE

EALIFURNIA 


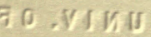

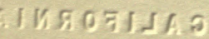




\section{CHAPTER XIV.}

GROUND VARIOUS, MARKED WITH SPOTS AND IRREGULAR LINES.

HAWFINCH.-Coccothraustes vulgaris. Plate XVIII. Fig. 3.

The only nest of this bird which I have ever seen was found high up in a young oaktree, the foundation being composed of twigs, and all the remainder of the nest consisting of the grey tangled lichen, which is found growing on the branches of old trees. The whole was very loosely put together, and seemed to show that, expert though the Hawfinch is in cracking the stones of cherries and haws with his ponderous beak, he does not possess much skill as a weaver. It contained five eggs, of a very light olive-green hue, with a few brown spots, and numerous irregular lines of a lighter tint, varying greatly in length, thickness, and direc- 
tion. So peculiar are its colour and markings that it cannot be confounded with the egg of any other British bird.

\section{Common Bunting.-Emberiza Miliaria.}

\section{Plate XVII. Fig. 2.}

The nest of this bird is usually placed at the border of a field, only a few inches from the ground, and supported by the tangled stems of low shrubs and dry grass. The eggs, which are four or five in number, are about an inch long, of a reddish or purplish white, blotched and speckled with dark purple, and with here and there a few irregular lines of the same colour.

Yelilow Hammer.-Emberiza Citrinella. Plate XVII. Fig. 3.

LIKE the last species of bunting, the Yellow Hammer, or Yellow Bunting, mostly places its nest near the ground, under shelter of a bush at the border of a field, on the skirts of a common, or near the bank of a stream. Its 
nest is constructed of bents and roots and moss, lined with hair. It is a late builder, and hatches its eggs in June and July, the period when grasshoppers, the favourite food, it is said, of its young, are abundant. The eggs are very like those of the common bunting, less spotted, but smaller and marked with longer and more numerous lines.

\section{Reed Bunting.-Emberiza Schoniclus.}

Plate XVII. Fig. 1, and Plate XVIII. Fig. 1.

The nest of the Reed or Black-headed Bunting differs but little from the preceding. It is, however, most frequently placed near the margin of a river or canal, especially where reeds or rushes are abundant. The eggs are four or five in number, of a dull purple brown colour, marked with broad, irregular curved lines of darker purple. From the following incident, related by Mr. Neville Wood, it appears that this bird must be classed among those which display an unusual amount of 

210
BIRDS' NES'TS.

instinct in preventing their nest from being discovered. "Some years ago, when walking with a friend, I remember seeing two of these birds in an osier bed, the male perched erect at the summit of a willow stem, and his mate remaining beneath, only occasionally coming within view. On our entering the osiers, they both flew round us in great alarm, mostly in silence, but sometimes uttering a low, mournful kind of note, at the same time darting suddenly about the hedge and willow stems, as if impatient for our immediate departure; and their manners were so different from those commonly observed in the species, that we were convinced that there must be a nest thereabouts. I was well aware of the difficulty of finding its little tenement in a situation of that kind, and accordingly we both of us began to move in different directions, in order to discover, by the actions of the birds, where their treasure lay. My friend traversed one side of the osier bed, and myself the 


\section{$-2$}

REE D BUNTING

e
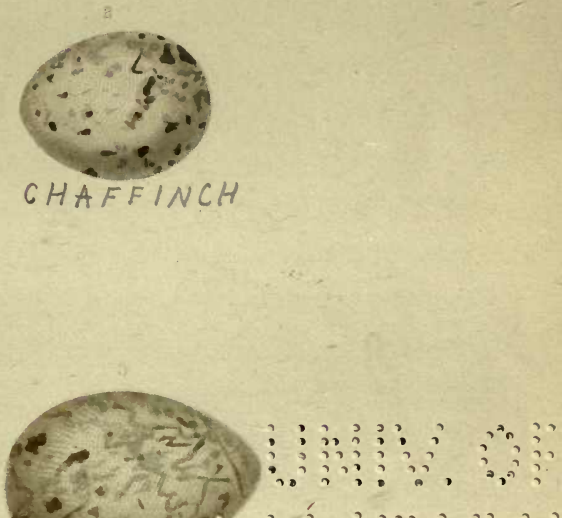

E HAW FINCHI 

other; but still the loving and faithful couple remained in precisely the same spot where the junction of two hedgerows formed a corner, and we therefore concluded, naturally enough, that in that spot all their hopes were centered. But a close and minute investigation of the whole corner, during which time we laid the ground completely bare, revealed nothing to us. At length, a full hour after the commencement of our labours, I hit upon the nest by mere chance, at exactly the opposite end to that at which the reed buntings had been, and still were, prosecuting their whinings and manœuvres, which now proved beyond a doubt, what I had never before suspected, that the birds had been all the time endeavouring to attract our attention towards them instead of towards the nest."

\section{Chaffinch.-Fringilla ccelebs. Plate XVIII. Fig. 2.}

Few nests surpass that of the Chaffinch, either in elegance, selection of materials, or 

212
BIRDS' NESTS.

skill with which the various substances employed are felted together. The bird itself has the style and deportment of a rustic beau, and constructs a habitation in accordance with his own air of neatness and propriety. Not content with making it snug and comfortable within, he expends as much care on the outside as on the interior, and finishes off the edge with as much symmetry as if it had been modelled in a turning-lathe or on a potter's wheel. The main substance of the nest consists of moss and wool, felted together with wonderful skill. The outside and rim are decorated with spangles of white and green lichen, picked from the bark of trees. Instances are recorded in which the bird, instead of using the white lichen described above, has employed tiny scraps of white paper, or, in the neighbourhood of cotton-factories, small tufts of cotton wool. It is commonly said that the chaffinch thus studs its nest with lichens, in order that it may present as close a 
resemblance as possible to the tree in which it is placed; and, indeed, when the nest is built in the fork of a branch, it is often difficult to distinguish it; but when it is situated, as is often the case, in a thick bush, or among twigs of a tree on which no such lichen is growing, it can be actuated by no such motive; for here the variety of colouring tends rather to betray than to conceal it. For my own part, I cannot help thinking that the smooth exterior, the beautifully rounded margin, and the varied colouring, are so many evidences, that the sole end of the bird is not concealment, but that it is a natural appreciation of what is beautiful in form and colouring. The interior of the nest is thickly lined with dry grass, wool, feathers, thistledown, and hair, and, in fact, any soft material that can be met with. The eggs, usually five, are of a greenish purple or buff hue, variously spotted, and streaked with dark purple. 
214. BIRDS' NESTS.

\section{CHAPTER XV.}

ON the Saturday following the incidents recorded in the chapter preceding the last, Mr. Miller, accompanied by his son, paid a visit to the market-town of $\mathrm{K}$-, distant about six miles from their house. As they went in a carriage, there was no possibility of pursuing the new study, though Henry's eye followed every bird that crossed the road, and frequent were the exclamations - "What a good place for a whitethroat's or a chaffinch's nest!"

As they drew near the town, the unusual number of carts, horsemen, and people on foot, showed that it was market day. Henry, who lived quite in the country, and rarely visited the town, soon became so much interested in watching all that was going on, that for a time he forget his late engrossing amusement. 
Having put up his horse at the inn, $\mathrm{Mr}$. Miller, still accompanied by his son, made his way as well as he could through the rows of baskets, and crowds of market-people, to the Town Hall, an old but venerable building, supported on pillars, the upper floor of which was used as a room for the magistrates to meet in, and the lower as a corn-market.

It was now a few minutes past the usual time of meeting, so that when they entered, the magistrates had taken their seats, and business was about to commence.

A policeman made way through a crowd of country people, and opened a barrier through which the father and son passed, and seated themselves on a bench a little to the left of the magistrates. Mr. Miller was himself in the commission of the peace; but, for certain reasons, he did not wish to act on that day, so he simply bowed to his brother magistrates, and continued a mere spectator.

The first visit to a court of justice always 

216
BIRDS' NESTS.

makes a great impression, and Henry was much struck by the grave appearance of all that he saw. The old, dark, heavy pictures, the carved roof, the formal benches, with a long table beneath, the quiet demeanour of the people, who, instead of talking and laughing, were evidently intent on what was going on : all these things had a powerful effect on the boyan effect, too, which was much heightened by his not having been told beforehand where he was being taken. But how much greater was his surprise when he saw, standing by himself in a little oblong box or pen, opposite the magistrates' seat, no other than Bill Johnson! The whole truth flashed upon him; the unhappy boy had been taken up for some dishonest act, and was now brought before the magistrates to be examined. Perhaps he had been in prison, or would be taken to prison, or would be transported, or have to work in chains as a convict. Before, however, he could recover from his feeling of wonder and terror 
at this, to him awful sight, sufficiently to ask his father the meaning of what he saw, business commenced, by some one calling in a loud voice for the "witnesses against William Johnson."

Presently a man forced his way through the crowd, whom Henry immediately recognised as Thomas Morris, whom his father often employed as a carpenter about the house. This man stepped into another little pen, where he could be seen both by the prisoner and the magistrates. The clerk handed him a Testament, and told him to swear that the evidence he was about to give was "the truth, the whole truth, and nothing but the truth." The witness pressed the book to his lips; the clerk sat down, and the magistrate who sat on the highest seat in the middle, asked him his name and occupation.

He answered distinctly, “Thomas Morris, carpenter."

"Now state what you have to say against the prisoner." 
"Why, your worship, about six o'clock last Wednesday morning, William Johnson, the boy standing at the bar, came into my shop, as I was at work about a corn-chest, and asked me if I wanted to buy a pheasant. I said, Certainly not, as it was unlawful to kill or have a pheasant at this season. 'I wish you would buy it,' said he ; 'it is a very fine one, and you shall have it for a shilling, and you will be able to make a great deal more than that by it." ",

"Pray," interrupted the magistrate, "are you licensed to deal in game, that people bring you pheasants for sale?"

"No! your worship."

"How came it then, that the prisoner thought of bringing the pheasant to you rather than to any one else?"

"Why, Sir, in my leisure hours in the evenings, and when work is slack, I amuse myself with stuffing birds, and when anything uncommon is shot in the neighbourhood, it is gene- 
rally brought to me, that I may tell its name. The gentry often employ me to set up such things for them; but if anything uncommon is brought by any one who does not want to have it, I offer a trifle for it, and when I have stuffed it, I either keep it myself, or sell it, if I can get a customer. Bill Johnson must have known that very well, and thought, I suppose, that I should be sure to give a shilling for so large a bird as a pheasant."

"Well," said the magistrate, "what happened then?"

"Why, your worship, all at once it occurred to me that it was unlikely that he should have a pheasant in his possession by honest means, at any time of the year, and that it was certainly contrary to law that he should have one now in the egging season; and if that were so, I thought it would be my duty to find out, if I could, how he came by it; so I said, 'But I must see it first, and hear where you got it.' Upon this he opened a paper parcel, and took 
out the bird which the policeman has in his hands, and said that he had been nesting that morning in Cobb-wood, and that all at once he heard a gun go off, and was frightened at first, thinking that some one was firing at him for trespassing. When he looked round, however, he saw a man whom he did not know, with a gun in his hand, in the act of picking up a pheasant that he had shot. Just then the man turned and saw him, asked him who he was, and what business he had there? He said, however, he was not to be frightened, and had as much right there as the man, and that he would inform against him for poaching, and get the penalty. 'Upon that,' said he, 'the man said he did not care, because I did not know who he was, but that I had better not make a stir about it, and that if I would go away quietly, he would give me the bird he had just shot; but that if I followed him, he should think no more of shooting a jailbird than a pheasant. So I took it, and came 
straight here to you.' This was his story, Sir."

"And what made you doubt it?" said the magistrate.

"Why, Sir, in the first place, I knew the keepers kept too strict a watch in Cobb-wood at egging-time, to let any poachers come there by broad daylight; and, in the next place, I looked carefully at the pheasant, and saw that it had not been shot at all, but had been killed by having its neck twisted. So I said to him, 'Now, you are not going to impose upon me with that nonsense. This is a hen pheasant that has been caught sitting; the feathers have been all rubbed off her breast,' (and if your worship will please to look at the bird, you will see that it is as I say,) 'and it's my firm belief that you caught her on the nest, and have stolen the eggs. So, unless you can produce the man who gave it to you, I shall take the bird to Mr. Long or Mr. Miller, and have a warrant against you.' 
"And what did he say to that?"

" He began to talk very impudently, and said I might go if I liked; but that I had no business to steal his bird, for no one could prove that he had come by it dishonestly. But I kept it safe, until I was told to give it up to the policeman."

"Prisoner," said the presiding magistrate, "do you wish to ask this witness any questions? Remember, what you say will be written down, and used against you."

"I never killed the pheasant," muttered Johnson, in a sulky tone; "I saw a man shoot it on Wednesday morning in Cobbwood, and he gave it to me for not informing against him."

"Have you anything more to say?"

"No; except that Mr. Morris has been telling a pack of lies against me, because I broke a pane of glass in his shop last winter. Many's the pheasant he has poached himself."

The witness was about to reply, when one 
of the magistrates stopped him, by saying that he knew him to be an honest man, who would neither tell a falsehood, nor harbour malice against his neighbour.

"Is there any one here who can say anything in favour of the prisoner's character?" asked the chairman. "Prisoner, have you any witnesses?"

Johnson looked vacantly round the room, and said, in his usual impudent tone, "Yes, plenty; but you have taken good care to have none of them here."

The magistrates began to whisper together, when Mr. Miller stood up and said, he believed he could throw some light on the matter; " but," added he, "I must be allowed to step into the witness-box." He accordingly went down to the body of the court, and the oath having been administered to him in the usual form, he narrated all the particulars of his finding the pheasant's nest, as given in the last chapter. When he had finished, he drew 
224 BIRDS' NESTS.

from his pocket the piece of paper which he had found sticking to the bramble, and handing it across the table, begged the magistrate to see whether it corresponded with the paper in which the pheasant had been wrapped. Both pieces were now handed up to the bench, and so intense was the excitement, that no sound was heard except the rustling of the paper, as the magistrate unfolded it, and searched for a place from which a piece had been torn. The paper was very much rumpled and uneven, so that it took some time to flatten it. Meanwhile, Mr. Miller glanced at the miserable prisoner, and if ever convicted guilt was visible in a culprit's face, it was clearly written in Johnson's.

The rustling ended; all three magistrates bent their heads over the desk, on which the paper was spread; the silence became if possible yet more intense, but at last was broken by the chairman's rising, and holding up the paper with the little piece so accurately fitted 
in, that it was impossible to doubt that the two had once formed one and the same sheet. And not only did the pieces exactly correspond in shape, but the fracture had been made through the word GAZETTE, printed at the top, in such a way that the $G$ and part of the A were on the small piece, and the rest on the large.

"We have no doubt," said he, " that this small piece of paper once formed a part of the same newspaper with the large. Since this, however, is a serious matter, I will thank you, Mr. Miller, to answer a few questions that I am about to put to you, not that we doubt your word, but in order to afford the prisoner every chance of proving his innocence. Pray, at what time on Wednesday morning did you make this discovery?"

"About half-past seven."

"What sort of weather had there been the previous night?"

"It rained very heavily when I went to bed 
at eleven o'clock; but at what hour it cleared up I cannot say."

"What was the state of the ground when you took your walk at half-past seven?"

"The grass was very wet; so wet, indeed, that I was deterred from walking through the meadow, according to my usual custom, and went by the path through the wood instead."

"Did you remark when you found the piece of paper, whether it was wet or dry?"

"I did remark, and am quite certain that it was barely damp; it could not possibly have been exposed to the rain of the previous night."

"That is just what I wanted to arrive at; but at this season of the year the sun rises very early, and may have dried the paper, since, as you say, it was hanging to a bush, and did not touch the ground."

"I do not think that that was possible, as the morning was cloudy; and even if the sun had been shining elsewhere, it could not have 
penetrated the thick wood in which the incident occurred. I have no doubt that, however the paper came there, and by whomsoever brought, the time was early on Wednesday morning."

"You are acquainted with Cobb-wood, and know the residence of Mr. Morris, I presume?"

"Perfectly."

"Now, how far are they distant from the place where the paper was found, and from each other?"

"Cobb-wood lies ten miles north of the place where the pheasant's nest was placed; and Mr. Morris's, four miles to the east. The distance between Cobb-wood and Mr.Morris's is rather more than twelve miles."

"And where does Johnson live?"

"About two miles from the nest."

"If I understand you rightly, then, if the prisoner had visited both the pheasant's nest and Cobb-wood before he went to Mr.Morris's, 
he must have walked just two miles to the nest, then ten to Cobb-wood, and then twelve to Mr.Morris's, in all, twenty-four miles before six o'clock - a distance which it would have been impossible for him to perform without visiting one, at least, of the woods, by night, which could not have been for any honest purpose. Prisoner, do you wish to ask this witness any questions?"

Johnson made no reply, and the magistrate thanking Mr. Miller for the information he had given, begged him to resume his seat on the bench, much to Henry's satisfaction, who was not at all pleased to be separated so far from him in so terrible a place as the Guildhall now appeared to him.

'The magistrates now conferred together for a few minutes, and during this time every one in the hall seemed to be relieved from an oppressive weight. That Johnson had taken both bird and eggs no one doubted, though nothing had been said about the latter. The 

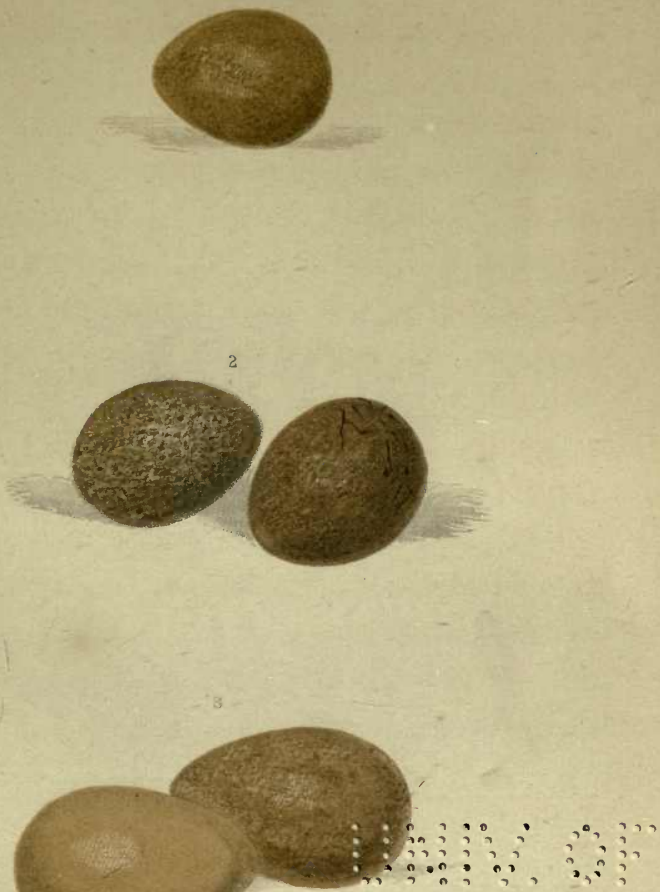

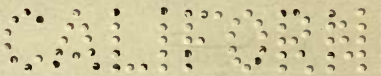

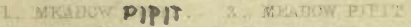



only doubt was what the sentence would be, and opinions passed from one to another, so that the breathless stillness which had before been so remarkable was now exchanged for a general whispering. This, however, was soon over. At a sign from one of the magistrates, an officer of the court proclaimed "Silence!" and every voice was hushed, while all eyes were turned towards the chairman, who, addressing Johnson, spoke as follows :

"Prisoner, we are of opinion that on the morning of Wednesday last, whether alone or in company with some other person we cannot say, you went to Mr. Long's wood, and surprised a hen-pheasant while sitting on her nest. What became of the eggs there has been no evidence to prove; but there is not a shadow of doubt that you cruelly killed the old bird, wrapped it in a newspaper, and offered it for sale to Thomas Morris. Now, the mere act of taking the eggs would make you liable to a severe penalty; but we have 
not thought it necessary to go into this, it being clear to us that we can satisfy the ends of justice without inquiring whether you took them or not. In the first place, then, you violated the law of the land by entering on Mr. Long's land, in search of pheasants' eggs, if you took them, or at all events, in search of game; secondly, you committed an illegal act by killing a pheasant, not having a game certificate,- though I may add, it is unlawful for any one to kill game at this season; and, thirdly, you violated the law by offering the pheasant for sale. Now, as you are a mere boy, it might be urged on your behalf that you did not know there was any harm in going into Mr. Long's wood - that you killed the bird merely out of reckless cruelty - and having killed it, you thought you might as well make a little money by selling it, being all the while in ignorance that you were doing anything wrong. That excuse cannot be made for you. Had you committed the offence in ignorance, 
the most natural course that you could have pursued, would have been to have told Mr. Morris the whole truth; and had you then been brought before us, we should have taken your youth into consideration, and probably have inflicted only a trifling penalty. Instead, however, of telling the truth, you endeavoured to shift the blame from yourself to some one else, thereby proving that you knew you had done wrong; and not content with this falsehood, you did all in your power, though without any effect, to injure the character of a man who, for truth, honesty and integrity, is on a par with any one in this hall. Taking into account, therefore, your evident consciousness that what you were doing was wrong, your falsehoods, and your malicious spirit towards Mr. Morris, we think we should not do right were we not to pass on you a severe sentence, which is, that you pay a fine of $3 l$., or be imprisoned for two months. I shall make it my 
business to see the chaplain of the gaol, and give him all the particulars of your story, in order that he may know that he has not to deal with an ordinary case of trespass, but a wretched mixture of falsehood, malice, and dishonesty. Well will it be for you if you listen to the good instruction which he will give you; otherwise, I am afraid to contemplate what your future course may be."

Johnson not being able, of course, to pay so large a sum as three pounds, was on the point of being removed by the constable, when he appeared at last to be affected by the wretched condition in which he had placed himself. Naturally impudent, he had never been checked by his parents, except when his impudence thwarted their will, and then he was punished with passion and severity, which hardened him yet more. Now, however, the great dignity of the magistrates, joined to the dread of being committed for the first time to prison, 
overawed him. He had been all along buoyed up by the hope, that his story about Cobb-wood was so plausible a one, that it must be believed; as he was quite sure in his own mind, that no evidence could be brought forward of his having been in Mr. Long's wood, except that of a man who could not inform against him, without getting himself into mischief.

The true state of his case was this. There lived a few miles off a bird-fancier, whose occupation was to catch linnets, bullfinches, and other small birds, and to sell them to the dealers in London; an employment so utterly unmanly and cruel in itself, that it could not but deaden the heart against all feelings of mercy and justice. To this iniquitous occupation he added the secret business of collecting either with his own hands, or by purchasing from any one who would supply them, the eggs of pheasants and partridges. - These he sold either to London dealers, or to 
a person calling himself a gentleman, who had bought an estate in the neighbourhood, and adopted this infamous method of stocking it with game. Johnson had often fallen in with this man, and had been fixed on as a boy who in time would become a very useful tool; for though he had never before been tempted actually to steal eggs, he had only refused from fear of being caught. The fear of doing evil in the sight of God he had long lost sight of. To cut the story short-partly by taunts, and partly by holding out a reward, the man at last induced him to take him to this wood, where Johnson in his birds'-nesting wanderings had found the pheasant's nest. The man was to stay outside in the road, and Johnson, if he brought out the eggs safe, was to have a shilling for his trouble. He did bring them out safe, and not only so, but caught the old bird on her nest; and, hardened by success, proceeded to Mr. Miller's garden, where he 
caught the duck also on her nest, and killed her out of spite to the owner. Little did he think that, by the providence of God, a trifling scrap of paper was to bring to light enough of the truth to prove him guilty. But so it is : the eye of God is always on us, and His finger often points out the criminal to man, in order that men may not run riot in their strong determination not to be found out.

But to return to the story, which is now drawing to its close. The dread of spending two months in prison so terrified Johnson, that when the constable proceeded to remove him lie clung to the rail, and falling on his knees, implored the magistrates to forgive him only this once, and he would never so offend again.

The magistrates' reply was strict and dignified. "We cannot now alter our sentence, as we cannot believe, after the hard-heartedness you have shown, that your repentance is 
anything more than sorrow that you have been found out. It is possible that you may have been led away by others to commit this crime; if so, you must now take the consequences. In the present state of affairs, our duty is to punish,-it is for God only to forgive. In prison you will be for a time separated from your late wicked companions, and will be taught in what frame of mind you ought to apply for that forgiveness. What we should have done, had your defence been a true one, is another question; but we cannot put any faith in the promises of one who a few minutes since endeavoured to screen himself, by blackening the character of an honest man." The prisoner was then removed, almost by force, and the court proceeded to other business.

Mr. Miller and Henry had a silent ride home that afternoon. And next day, before they went to church, Mr. Miller pointed out 


\title{
BIRDS' NESTS.
}

to Henry two passages in the Litany; they were these :

"From hardness of heart, and contempt of Thy word and commandment ;

\author{
"Good Lord, deliver us.
}

"That it may please Thee to show Thy pity upon all prisoners and captives;

"We beseech Thee to hear us, good Lord."

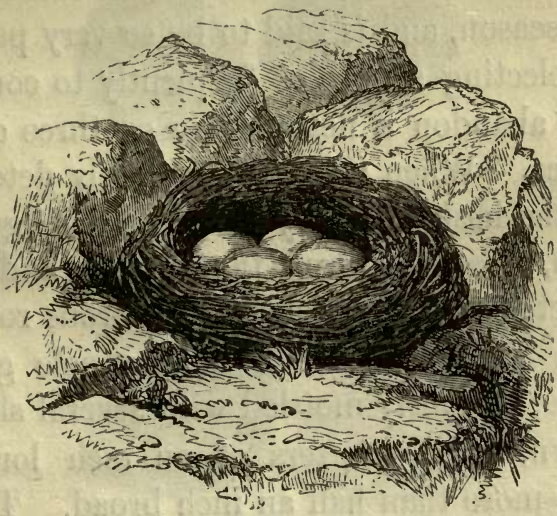




\section{CHAPTER XVI.}

GROUND VARIOUS, MOTTLED WITH GREEN OR BROWN.

BLACKCAP. - Curruca atricapilla. Plate XX. Fig. 3.

THIs, one of the most delightful of our summer warblers, builds its nest rather late in the season, and is said to be so very particular in selecting a spot as frequently to commence and abandon a nest in two or three different places. When a locality is finally determined on, the nest is usually placed in a hedge or low bush, a few feet from the ground, and is constructed of bents, lined with fibrous roots and hair. The eggs are five, of a pale greenish white, variously mottled with several shades of brown, three quarters of an inch long, and little more than half an inch broad. They resemble so closely those of the garden warbler, that it is impossible to decide between them 


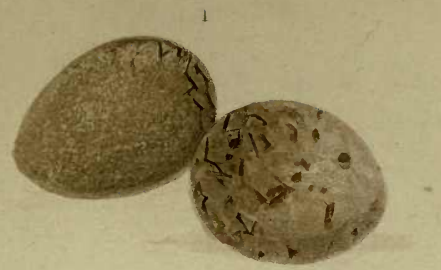

8

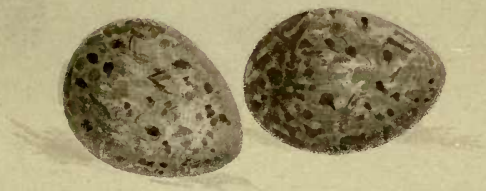

3

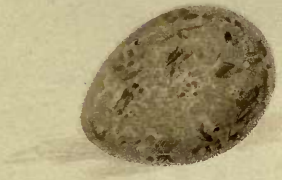

1. TREE PIRIT?

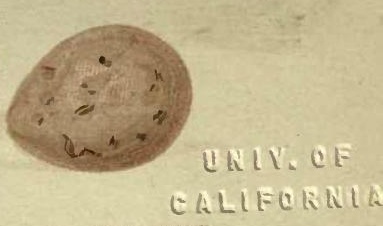

8. PRET: गTPTI 



\section{BIRDS' NES'TS.}

without watching the bird on its nest. Not uncommonly the egg's are all of a pinkish hue, mottled with light purple, and speckled with dark purple. This variety is so different from the preceding that no one would suppose the two to belong to the same bird. The male bird assists the hen in performing the office of incubation, and relieves the monotony of his occupation by singing, and thus often betrays a well-concealed nest.

Garden WARBLER.-Curruca hortensis. Plate IX. Fig. 1.

THe nest and eggs of this bird so closely resemble that of the preceding, that one figure and description might answer for both. I have not however observed that the Garden Warbler ever lays eggs of a pink hue.

Whitethroat.-Curruca cinerea. Plate XXI. Fig. 3.

Is many parts of the country this bird is best known by the name of Nettle Creeper, 
24.0 BIRDS' NESTS.

from its habit of frequenting hedges, and the sides of fields overgrown with brambles, nettles, and other such coarse herbage. In such situations it builds its nest, raised from two to three feet above the ground, and constructed of dry stems of herbs and bents, mixed with spiders' webs, cotton from the willow, and bits of wool, and with fine grass and horse-hair. 'The eggs are usually five, three quarters of an inch long, and about lialf an inch broad, of a dull green hue, mottled and spotted with several shades of olive. The short conversational song of the male in the breeding season, as he rises from the top of a bush a few feet into the air and alights on some neighbouring bush, is very remarkable.

Sedge Warbler.-Salicaria Phragmitis. Plate XXI. Fig. 2.

During the whole of its stay with us, from April to September, this bird frequents the banks of rivers, especially such as are lined with reeds, flags, or low willows. He is a most perse- 

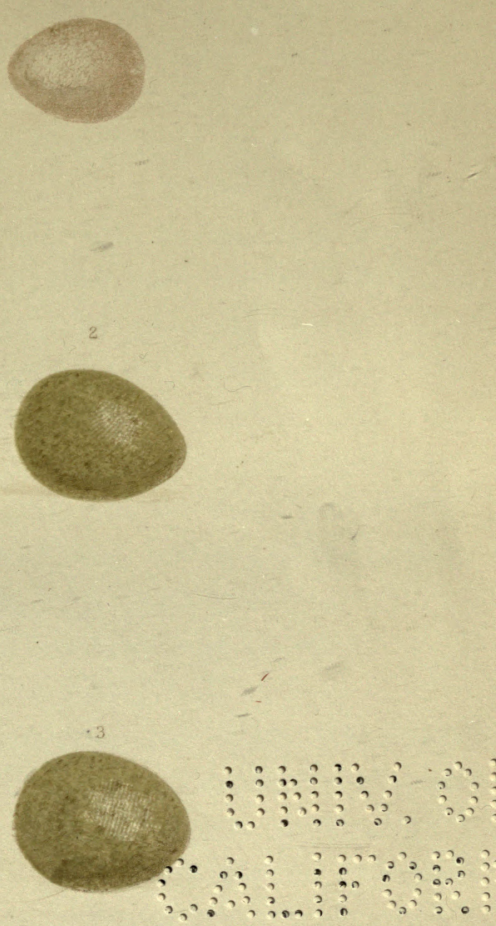

vering songster, and especially exerts himself when any one intrudes on his domain, flying from one reedy thicket to another, and continuing his song till late at night. The nest is usually placed among brambles, thorns, or other bushes, at no great distance from the river's bank. It is constructed of dry stalks, moss, and grass, and lined with hair, and small in proportion to the size of the bird, but unusually deep. The eggs, from four to six in number, are little more than half an inch in length, and vary greatly in width, being sometimes nearly orbicular; the ground colour is light greenish brown, and the markings are not unlike those of the whitethroat, light olive brown.

\section{SkYLARK.-Alauda arvensis.}

Plate XIX. Fig. 2.

Wнo is there that does not know the name and something of the habits of the bird that soars highest, sings loudest and longest, never alights on a tree, and builds its nest on the ground? Who has not peered intently into the blue vault 
of heaven, and watched the vocal speck in the firmament, wheeling aloft in airy circles, fluttering with untired wing, and, the symphony ended-

"Sinking like an arrow to his humble home!

The dasied lea he loves, where tufts of grass

Luxuriant crown the ridge; there, with his mate,

He founds his lowly house of wither'd bents

And coarsest spear-grass; next the inner work

With finer, and still finer fibres lays,

Rounding it curious with his speckled breast."

Numerous as the nests of these birds must be, and placed where one would imagine them to be easily detected, they are not often found, except by haymakers and other persons actually employed in the fields, owing, perhaps, partly to the thickness of the herbage at the season of incubation, and partly to the closeness with which the female bird sits on her eggs. Mr. Blyth mentions an instance in which "some mowers actually shaved off the upper part of the nest of a skylark, without injuring the female, who was sitting on her 
young; still she did not fly away, and the mowers levelled the grass all round her without her taking further notice of their proceedings. A young friend of mine, son of the owner of the crop, witnessed this, and about an hour afterwards went to see if she was safe, when, to his great surprise, he found that she had actually constructed a dome of dry grass over the nest during the interval, leaving an aperture on one side for ingress and egress, thus endeavouring to secure a continuance of the shelter previously supplied by the long grass." Two or three instances are recorded of the skylark removing its eggs, and even its young, in time of danger. The eggs, four or five in number, are of a light greenish ground, mottled all over with ash brown, varying greatly in deepness of shade in different specimens; not unfrequently the markings are wanting, when the egg appears of a uniform greenish brown. Both nest and eggs of the Woodlark (Alauda arborea) are very similar to those of the skylark. 


\section{CHAPTER XVII.}

EGGS VARIOUS.

\section{LAPWING.-Vanellus cristatus.}

Plate XXII. Fig. 1.

'THE eggs of this bird are so diligently sought for as an article of luxury, or rather display, for the tables of the wealthy, (for, in reality, there is nothing particularly delicious in their flavour, that it is almost a wonder that Lap. wings have not been long ago extinct. The affection of this bird for its young is very remarkable, and deserves a better fate. It makes a very slight nest, little more, indeed, than a few dry bents collected in a hole in the ground; and here it lays four eggs, about two inches long, of a deep olive-coloured ground, blotched and spotted with black. The female 


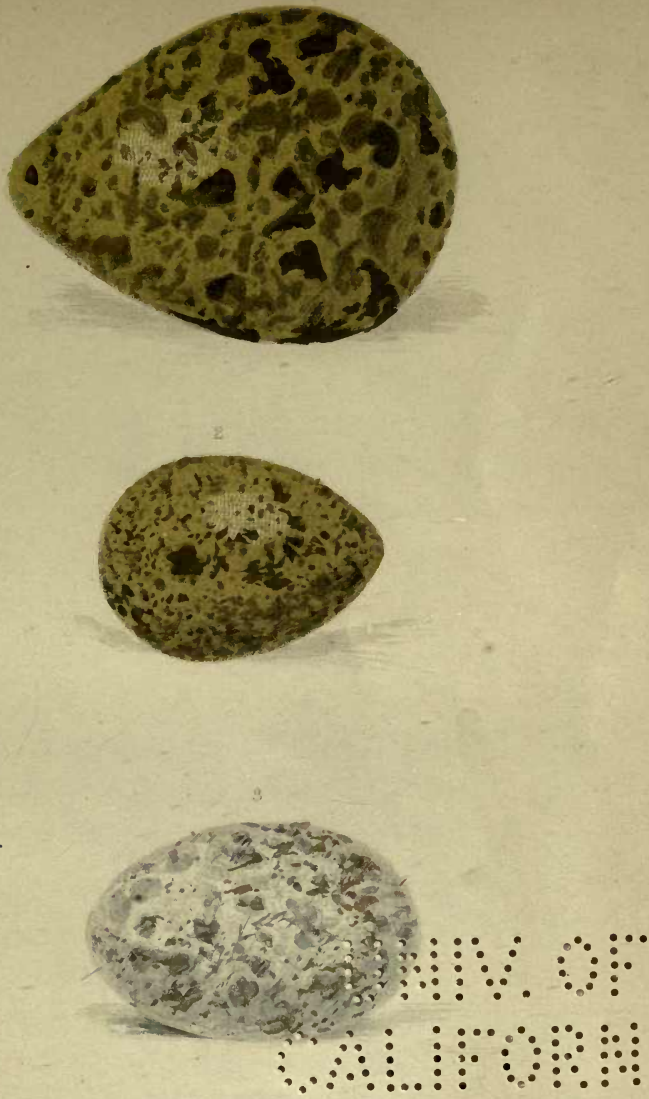



bird, when disturbed, runs along the ground, and then flies for a short distance with a shuffling movement, as if wounded. Meanwhile, the male bird flies round the head of the intruder with a peculiarly irregular flapping of the wings, both seemingly endeavouring to divert his attention from the nest. So lucrative, however, is the traffic in plovers' eggs, that the persons who partially gain their livelihood by collecting and selling them, study the instinctive efforts of the birds, and by practice are enabled to interpret their movements so accurately, as to guess not only the exact position of the nest, but the number of eggs which it contains.

NIGHT JAR.-Caprimulgus Europceus. Plate XXII. Fig. 3.

The Night Jar, Goatsucker, or Fern Owl, builds no nest, but lays two eggs on the bare ground, sometimes under the shelter of a 
bush, but very frequently on a dry exposed common, or on a rock. The eggs are very beautiful, white, mottled, and veined with bluish grey, and having somewhat the appearance of marble.

\section{Tree Pipit.-Anthus arboreus.}

\section{Puate XX. Figs. 1 aNd 2.}

The nest of the Tree Pipit is constructed of moss and dry grass, and lined with fine bents and hair, and is always placed on the ground, either on the skirt of a wood, or in the open glade of a grove. The eggs vary so much in colour and marking, as almost to defy description. Accurate representations of the principal varieties are given in the plate. The Meadow Pipit (Plate XIX. Figs. 1 and 2) and Shore Pipit construct nests very like that of the Tree Pipit, the former in the open country, the latter in the neighbourhood of the sea-shore. The eggs, from four to six in num- 
ber, are reddish brown, spotted and mottled with a deeper tint of the same colour.

Golden-CRESTEd Wren.-Regulus cristatus.

\section{Plate XXI. Fig. 1.}

As this exquisite little bird, by its minute size and rich colouring, suggests the idea of the humming birds of the tropics, so its nest, as elegant and symmetrical as itself, is no less worthy of being preserved under a glass dome than the tiny specimens of bird architecture which are among the choicest ornaments of our museums. (See page 39.) In form it resembles a deep cup contracted at the mouth, and is constructed of fine moss skilfully interwoven, and thickly lined with feathers. Its usual position is near the extremity of one of the lower branches of a spruce or silver fir, with the needle-like leaves of which the moss is curiously interwoven, the architect skilfully contriving that it shall 
enjoy the shelter afforded by the branch next above. The eggs are from six to ten, of a delicate pink before they are blown; afterwards cream-coloured, and faintly clouded with light reddish brown.

\section{THF END.}




\section{Society}

FOR

\section{Q⿻}

\section{BOOKS SUITABLE FOR PRESENTS.}

The vhole of these Works may be had in ornamental bindings, with gilt edges, at an extra charge of $6 d$. each.

Price.

ALICE GRAY; or, the Ministrations of a Child . 20

AMY'S TRIALS; or, a Character misunderstood 20

ANCIENT EGYPT. By P. H. Gosse, Esq. . . 20

ASSYRIA. By P. H. Gosse, Esq. . . . . 80

BINGLEY'S EMINENT VOYAGERS • . . 40

BOOK of BOATS . . . . . . . . 28

BRITISH SETTLEMENTS in INDIA, History of . . . . . . . . . 28

BROKEN ARM, The......... . 24

BUT ONCE. A Tale . . . . . . . 16

CHANNEL ISLANDS, Rambles among the . 30 CHAPTERS on COMMON THINGS by the SEA-SIDE. By Anne Pratt . . . . 40 CHEMISTRY of CREATION. By R. ELLIS,

Esq. . . . . . . . . . . 50 
BOOKS SUITABLE FOR PRESENTS.

Price.

s. $d$.

CONTRAST; or, Life at Home and in Service . 16

ELDAD the PILGRIM . . . . . . . 30

ERRAND BOY, The. By Charlotte Adams $\quad \begin{array}{ll}1 & 6\end{array}$

EVENINGS at the MICROSCOPE. By P. H.

Gosse, Esq. • • • • • • • • . 80

FIRESIDE TALES. First \& Second Series each 18

FLOWERS of the FIELD. By Rev. C. A. JoHns 68

FOREST TREES, 2 Vols. By Rev. C. A. JoHns 78

GARDENING for CHILDREN. By Rev. C. A.

JoHns . . . . . . . . . . . 26

HANNAH LAVENDER; or, Ladyhall . • . 18

HISTORY of the JEWS. By P. H. Gosse, Esq. 20

JOHNSONS, The. A Tale . . . . . . 14

LIFE of NELSON . • • • . . . . . 28

LIFE of WELLINGTON . . . . . . 20

LET WELL ALONE. A Tale . . . . . 14

MARGARET ARNOLD. A Tale . . . 20

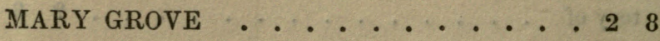

MARY MORTON and her SISTER •. . . 116

MILITARY LIFE, Tales of . . ... . 24

MOUNTAINS Of SCRIPTURE . . . . . 28

NATURAL PHENOMENA: the Rainbow, \&c. . 20

NICHOLLS' HELP to READING the BIBLE . 28

NO LIE THRIVES. A Tale ....... 18 
BOOKS SUITABLE FOR PRESENTS.

Price.

s. $d$.

OCEAN, The. By P. H. Gosse, Esq. . . . 48

OLD ARM CHAIR, The. A Retrospective

Panorama of Travels by Land and Sea . . 30

OUR NATIVE SONGSTERS. By Anne Pratr.

73 Coloured Plates . . . . . . . 80

PARIS, RAMBLES ROUND. By Rev. C. A.

Johns . . . . . . . . . . 30

PITCAIRN : the Island, the People, and the

Pastor. By the Rev. T. B. Murray, M.A.

Ninth Edition . . . . . . . . . 20

POISONOUS, NOXIOUS, and SUSPECTED

PLANTS. By Anne Pratt. 44 Coloured Plates 60

RAMBLES in the BRITISH ISLES . . . 18

ROBINSON CRUSOE . . . . . . . . 40

SCENES in the CAMP and FIELD; being

Sketches of the War in the Crimea . . . 20

SCRIPTURE NATURAL HISTORY . . . 40

SHORT STORIES founded on EUROPEAN

HISTORY.-FRANCE, ITALY, SPAIN,

SWEDEN .......... each 20

SISTERS, The. By Mrs. TomLinson . . . 30

STORIES from ROMAN HISTORY . . . 30

- of the NORSEMEN •... . 16

for the NURSERY . . . . 20

SKETCHES OF RURAL AFFAIRS . . . 34 
BOOKS SUITABLE FOR PRESENTS.

SUMMER in the ANTARCTIC REGIONS.

Price.

s. $d$.

With Map • • • • • • • • • . • . 20

TEMPEST, The; or, an Account of the Nature,

Properties, Dangers, and Uses of Wind, in

various Parts of the World . . . . . 28

TEXT BOOK of ZOOLOGY. By P. H. Gosse, Esq. 34

THREE CRIPPLES, The . . . . . . 10

TWINS, The; or, Home Scenes . . . . 18

TWO FIRESIDES, The. A Tale . . . . 20

WALTON'S LIVES of HERBERT, HOOKER,

SANDERSON, DONNE, and WOOTTON.

With Portraits . . . . . . . . 40

WANDERINGS through the CONSERVATO-

RIES at KEW GARDENS . • • . . 28

WILD flowers. By Anne Pratt. 2 Vols.

192 Coloured Plates . . . . . . . 160

WINTER in the ARCTIC REGIONS. With

Map . . . . . . . . . . 20

YEAR of COUNTRY LIFE; or, Chronicle of the Young Naturalist . . . . . 28

An Allowance of 25 per Cent. to Members.

DEPOSITORIES :

77, Great Queen Street, Lincoln's Inn Fields; 4, Royal Exchange;

16, Hanover Street, Hanover Square. 




\section{$\overline{\mathrm{M}} 85609$}

$621675-$

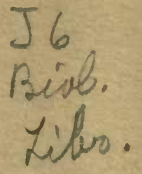

LOCKED

CASE

\section{THE UNIVERSITY OF CALIFORNIA LIBRARY}




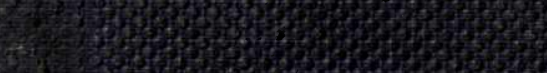

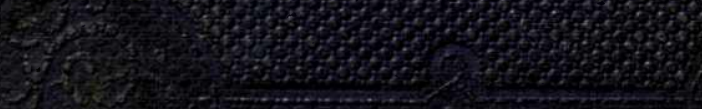

